\title{
1 Indus Musicians in Mesopotamia
}

2 Bull Lyre of Indus Valley and 90 words that Harappans

3 May Have Spoken

4

Shail Vyas

6

7

Homi Bhabha Fellow, Mumbai

shail@songsofmystery.org

\section{Abstract}

Human is a musical creature. It is seen ubiquitously through times and spaces that a certain percentage of human population is always musically inclined irrespective of their profession. Music is also an integral part of many social activities humans generally observe like religious practices, marriages, deaths and what more. Due to the possible presence of Harappan population in Mesopotamia, it may be surmised that a number of Harappan musicians and some of their musical instruments could also have reached there. In this investigation, crucial help could also come from the fact that many a times, names of musical instruments travel with them.

On account of a very likely possibility of such an occurrence, a study of archaeological and Sumerian textual records in Mesopotamia was strongly suggestive of a significant presence of Harappan musicians and musical instruments in Mesopotamia. In fact, study of Sumerian text has shown that about 30 musical terminologies out of a total of nearly 60 , in the categories such as names of instruments, singers, names of songs and even musical notations, etc. in Sumerian (PSD) are found to be phonetically and semantically very similar to ancient Indian terms with some "Sumerianization". The study also demonstrated certain patterns in the way words were sumerianized. To verify the data, other words were studied from the areas that are related to Harappan presence in Mesopotamia based on the patterns obtained from musical 
terminologies; which yielded many more positive results. A total of 90 such words are found till now, which are reported here. Furthermore, the study of iconography in Mesopotamian archaeological records has also shown very compelling parallels in musical traditions. Importantly, it predicted a possibility of a Harappan lyre, shaped realistically like a bull, that may have travelled from Indus to Mesopotamia and evolved there in local styles in the forms as found in the Royal Cemetery of Ur.

\section{Introduction}

It is sad that Harappan Archaeomusicology hadn't been studied in any detail so far and Harappan music remained just a quick passing reference in publications. Present paper is a part of an ongoing effort to work towards a better situation. In a forthcoming paper, we discuss in detail some of the archaeological artifacts (iconography/toy forms/likely non-perishable parts of instruments) found at various Indus sites that show a possibility of presence of a

(a) Arched Harp, Drum (both are seen on seals)

(b) Multiple specimen of what are most likely different types of tuning pegs (made of ivory, bone and terracotta, sometimes decorated) with expected damage patterns, found at various sites indicating possibility of multiple types of stringed instruments. Similar pegs are used till today in the Indian subcontinent in a very large variety of instruments (c.f. Fig. 1.1-1.2 Harappan and modern tuning pegs). Fig 1.3 shows comparison of damage patterns in Harappan specimen and modern tuning peg of a Sitär. As apparent in both the cases, lower part is damaged more. This part goes inside the body of instrument and since the tuning is required to be adjusted frequently, more damage occurs to this part in general. String marks are present at similar position in both examples and appear fairly consistent, as musicians usually tie the strings quite neatly. Modern Sitär uses fine metallic strings but for Harappan specimen, it is more likely to be gut (or even silk?) (For presence of silk see Good, Kenoyer, Meadow 2009 "New Evidence For Early Silk In The Indus Civilization"). 
(d) Early Ocarina (vessel flute) type instruments found in miniaturized form of terracotta toy whistles. A tradition of similar instruments is still present in rural areas of Pakistan and India around some major Harappan sites. (c.f. Fig. 2 Harappan whistles and modern vessel flutes).

(e) Terracotta specimen of rattles; etc.

81

82

83
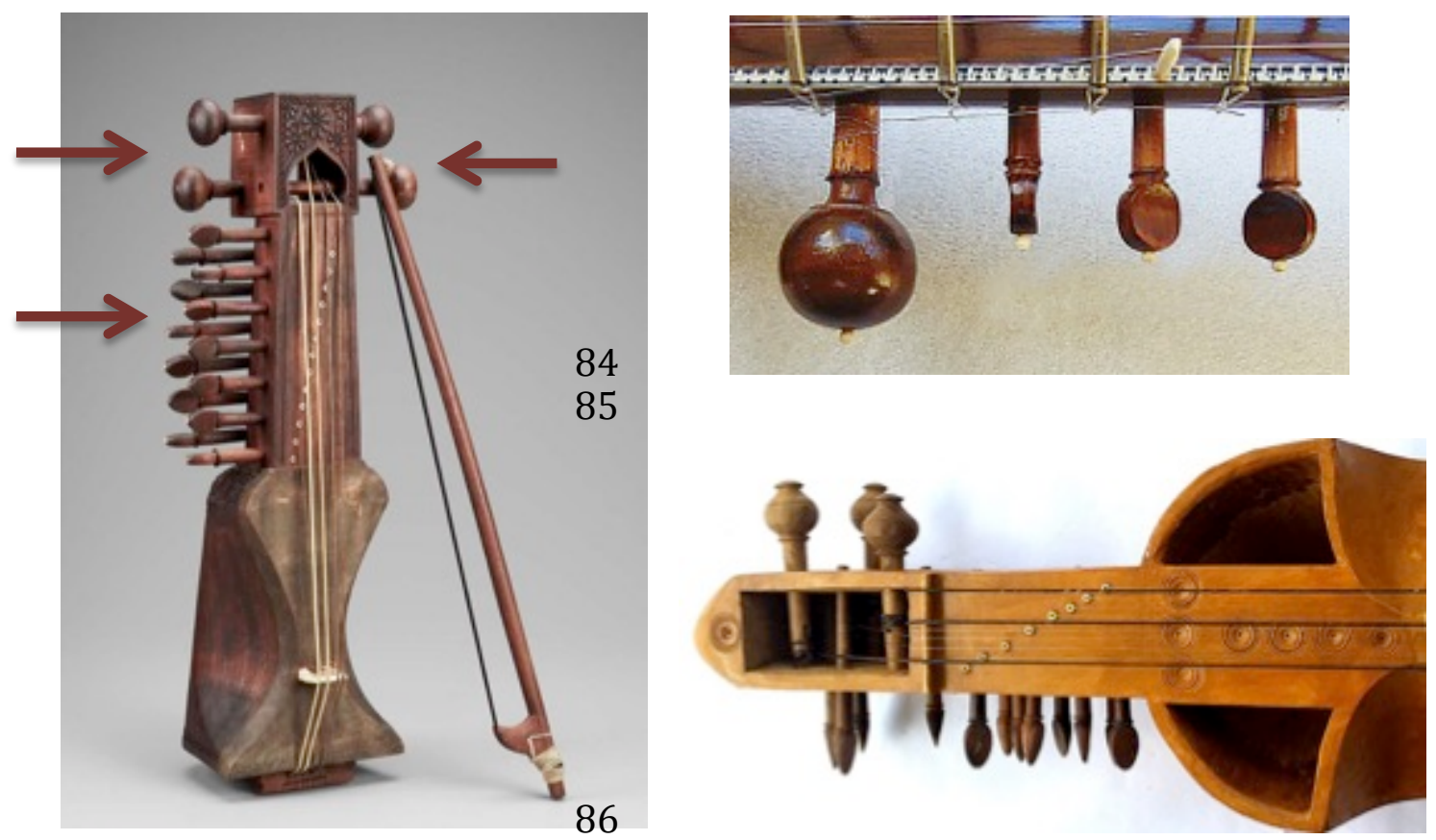

87

Fig. 1.1 Examples of use of tuning pegs (indicated by arrow) in south Asian instruments: (clockwise from left) sindhī sārangī, sitār, sārindā (many more examples can be seen in fig. 6 and 7)

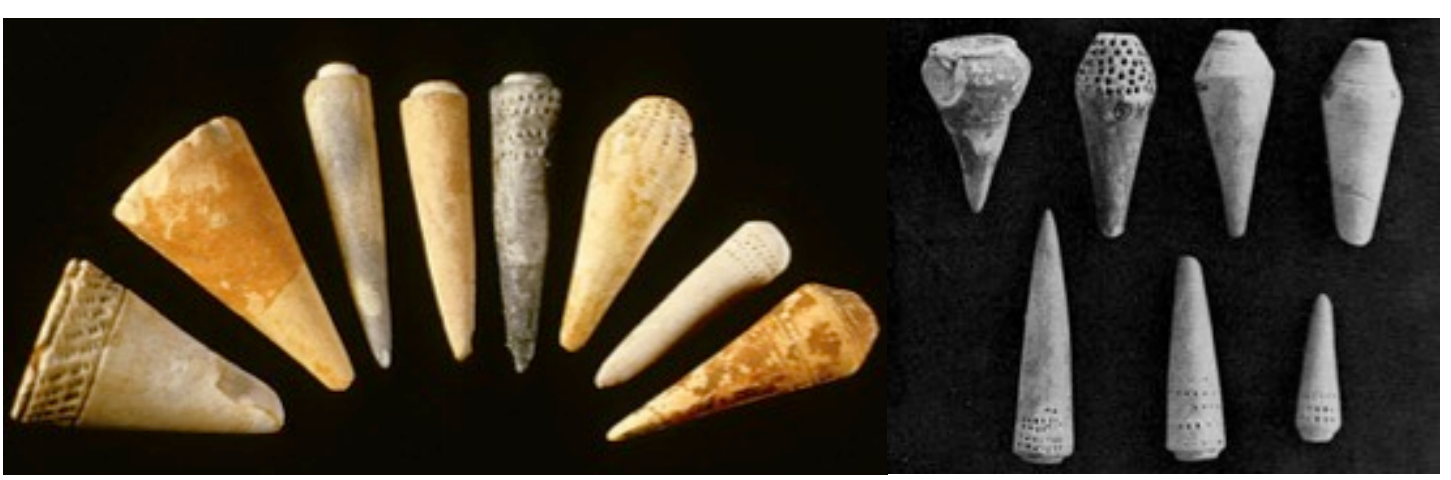

Fig. 1.2 some of the pegs (terracotta) found at various Harappan sites 

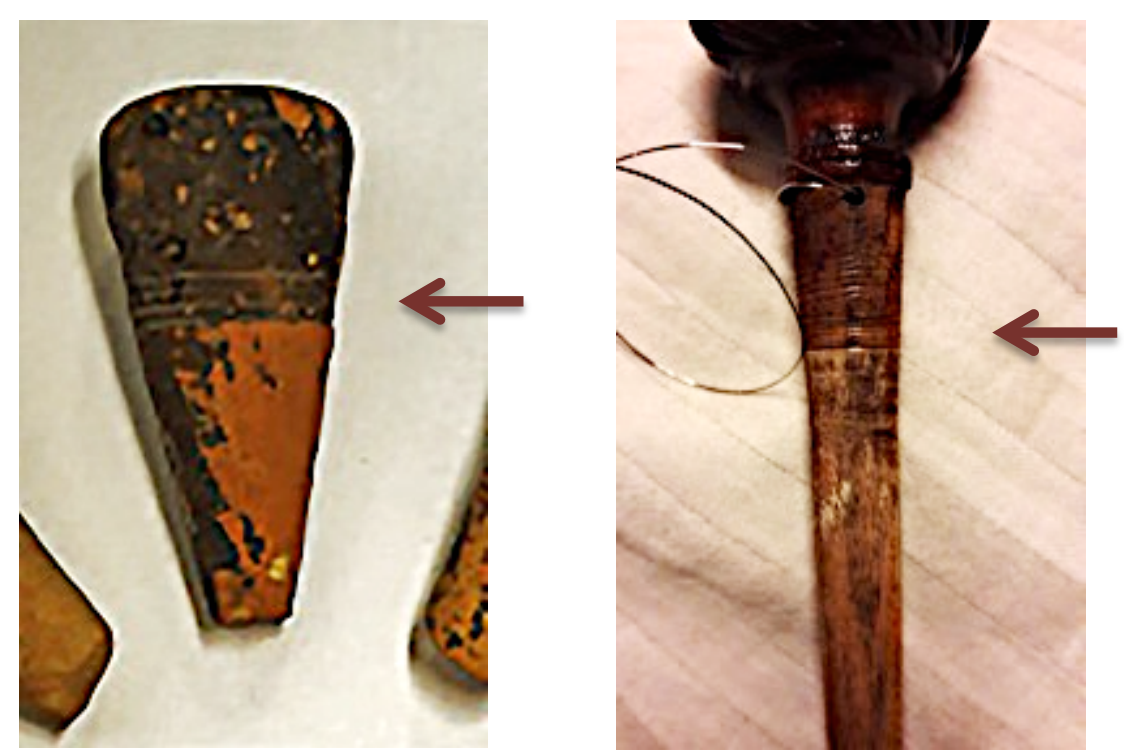

Fig. 1.3 A Comparison of damage patterns in (Left) a Harappan (terracotta) and (Right) modern Indian tuning peg (of a Sitār, wooden) (details in Vyas, forthcoming). In both the cases, lower part is damaged more. String marks (indicated by arrow) appear at similar position and are fairly regular in both, as musicians usually tie the strings quite neatly. Modern Sitar uses fine metallic strings but for Harappan specimen, it is more likely to be gut (or even silk?).
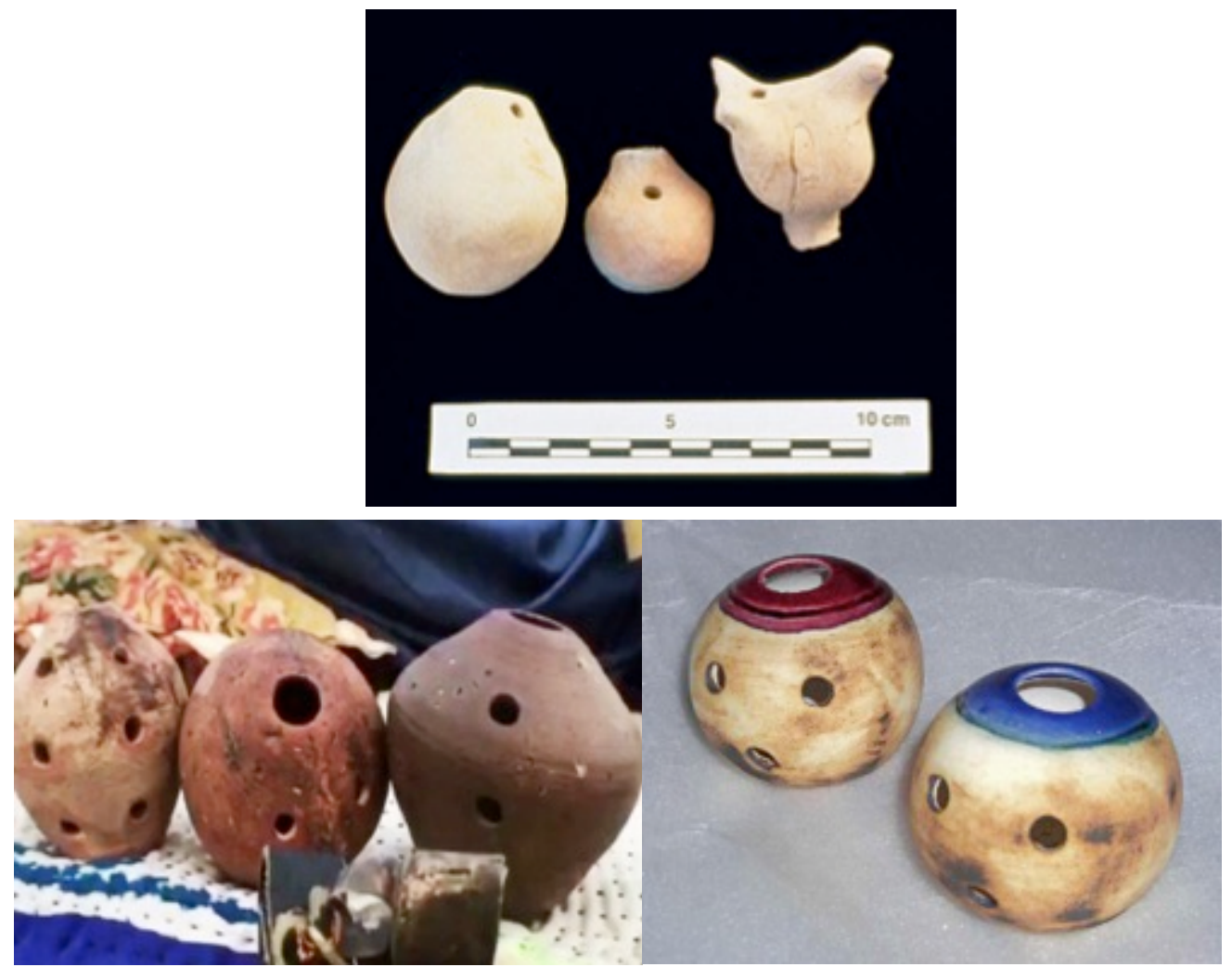

Fig. 2: Harappan toy whistles (above) and (Below) a tradition of similar instruments, which is still present in rural areas of Pakistan and India around some major Harappan sites. Only major difference between Harappan and modern ones is the number of holes. 
However, in context of a large urban civilization like Indus, presently available evidence in archaeology doesn't seem to give any comprehensive

113 account of music. Profuse use of perishable material in the manufacture of 114 instruments usually makes it very difficult in archaeology to provide any direct 115 evidence for actual instruments in reasonable detail. Most importantly, there is a 116 conspicuous absence of central temples, palaces and (especially) elaborate elite 117 burials (Kenoyer 2006a), where one would hope to seek better evidence, like in 118 Egypt or Mesopotamia. Another equally important issue is, according to Kenoyer 119 (2010) “(...) because the earliest phases of the Indus cities are deeply buried, 120 very few examples of early art have been recovered". Standardized nature of 121 majority of seals, which usually employs animals (real or composite/imaginary) 122 as main motif, further compounds the problem. Few parts of instruments, which 123 are non-perishable or a few fortunate depictions of instruments in iconography, 124 are the only help here. The Indus script remains undeciphered till date and with 125 presently available corpus of 'Harappan text' where about 5 signs is average total 126 length of a piece of text, i.e. on seals, how much a decipherment would directly 127 help in understanding the intricacies of their musical ideas is highly doubtful.

However, Indus was the largest urban civilization of its time. Sea-faring urban 130 Harappans built planned cities with water management and sewage systems, 131 implemented civilization wide standardizations for units of measurements and 132 seals, etc., had very developed craftwork and associated technologies and more. 133 It is highly likely that they had reasonably intricate musical traditions as well; it 134 is only natural that it would be so.

136 But there still are some untapped resources that can bring new knowledge, i.e. 137 the other contemporary cultures and civilizations with which Harappans traded. 138 Harappan articles, trade connections and even settlements are found at far and 139 wide places and the most important of them is Mesopotamia. According to 140 Massimo Vidale, "The connections between these ancient Bronze age 141 civilizations could one day help answer a lot of questions. People moved around 142 a lot more than we think, and interactions between cultures were just as rich as 143 they are today." Vidale's 2004 paper "Growing in a Foreign World: For a History 144 of the "Meluhha Villages" in Mesopotamia in the 3rd Millennium BC" is a good 145 reference here. The paper, in his own words, is "aimed at summarizing part of 146 the information piled since Gadd's paper (1932), and presently available on the 147 question of the Meluhhan communities in Mesopotamia". I'll reproduce a few 148 relevant passages here as needed. 
“In 1932, C.J. Gadd opened a new line of archaeological research, collecting and publishing in a fortunate paper a series of seals from Mesopotamia (found during

153 digs or acquired on the antiquarian market) sharing what he regarded as an "Indian style"'” (Vidale 2004). Since then numerous scholars have studied the nature of relations between both the civilizations. Connections between Indus valley and near east may have started quite early.

"Long-distance trade by navigation between the two poles of the Gulf was already established by late-Neolithic and early Chalcolithic times (Carter 2002a, 2002b). It was the beads and shell trade that, in Mesopotamia, in the Gulf, most probably at Susa and possibly even in Bactria, gradually promoted the local settlement of families of specialized merchants and craft-persons from the Indus valley, who channeled along their tracks the supply of raw materials and, in general, the complex know-how of the Indus crafts. Archaeological evidence pushes back the beginning of this process at least to the end of the 4th millennium BC, when Late Uruk Sumerian engravers frequently employed the colummella of the Indian shank shell (Turbinella pyrum) for their cylinder seals (Kenoyer, in print)“ (Vidale, 2004).

J. M. Kenoyer too, is of similar opinion about Harappans in near east, “(...) if people were moving from one region to the other, it is not unlikely that trading colonies were established at different locations along the trade route." He goes even further and suggests possibility of marriage exchange to solidify trade relations as documented in later historical periods (Kenoyer 2013). If true, this would obviously have implications in the spread of Harappan cultural elements in Mesopotamia.

Apart from the known settlement of Harappans, situated in the territory of the old city-state of Lagash, there is evidence that suggest colonies and trade enclaves of Indus merchants and craftsmen at many other sites in Mesopotamia (and surrounding area) like Ur, Kish, Susa, Elam and more.

The trade between Mesopotamia and Meluhha (the name of Indus in

184 Mesopotamian records, agreed by most scholars) flourished with time and by the 185 middle of third millennium BCE and later, a larger-scale trade is attested in 186 archaeological records. Meluhhan ships exported to Mesopotamia precious 
goods among which exotic animals, such as dogs, perhaps peacocks, cocks,

188 bovids, elephants (? Collon 1977) precious woods and royal furniture, precious

189 stones such as carnelian, agate and lapis lazuli, and metals like gold, silver and tin

190 (among others Pettinato 1972; During Caspers 1971; Chakrabarti 1982, 1990;

191 Tosi 1991; see also Lahiri 1992 and Potts 1994). In his famous inscriptions,

192 Gudea, in the second half of the 22nd century BC, states that Meluhhans came

193 with wood and other raw materials for the construction of the main temple in

194 Lagash (see Parpola et al. 1977: 131 for references).

“(...) Indus settlers in Mesopotamia intelligently established critical connections with local cults and temples. Besides temple overseers, in charge of scribes and craftpersons, keepers and financers of sacred gardens, traders transporting cereals for the temples (...) Wood, timber for construction, ships and wooden furniture are consistently mentioned as coming from Meluhha, and both the trade in timber and the overall industry had a strategic economic role in 3rd and early 2nd millennium economies" (Vidale 2004).

During Casper (1979) concludes, "When one sums up the salient points (...) and adds them to various applicable factors (...) then one is almost irresistibly drawn to the acceptance of strong cultural and/or commercial liaison, between Mesopotamia and Indus valley, already established in Early Dynastic-or pre Akkadian-times."

In this milieu, it is not unlikely that some Harappan musicians (and other

211 performing artists) may have also reached Mesopotamia. A few possible 212 scenarios could be as follows:

(a) It is seen everywhere in human societies that a certain percentage of population is always musically inclined, irrespective of their profession. Their level of expertise may vary but some of them would surely be very accomplished.

217 In the absence of outrageous number of ways of entertainment and complicated 218 life like modern times, it is highly likely that a larger percentage of people would 219 have been musically active in the past. Music is also an integral part of many 220 social (and personal) activities humans observe like religious practices, 221 marriages, deaths and what more. Therefore, on account of these very natural 222 reasons, the possibility of arrival of Harappan music in Mesopotamia seems 223 likely even for no other reasons. 
225 (b) For long distance trade, overland or maritime, it is likely that traders would 226 keep means of entertainment along with them. Some big and wealthy traders 227 could even carry along a reasonable orchestra, dancers or other performers with 228 them. This can be postulated a little further that these artists would also perform 229 for their friends, partners and wealthy customers in Mesopotamia (at the 230 banquettes perhaps), which would not only be helpful for trade but could also 231 have played a significant role in popularizing Harappan culture.

233 (c) Music (and other performing arts) itself is a profession and so is the business 234 of making and selling musical instruments. The manufacturing of musical 235 instruments would not be very different from that of royal furniture, which the 236 Indus trade centers were regularly supplying to Mesopotamia. The possibility of 237 involvement of Harappan craftsmen in the manufacture of musical instruments 238 in Mesopotamia is thus a tenable premise and as evidence suggest, could be the 239 case (see below).

241 This process may have its roots in early times of their relations due to these 242 natural and trade related reasons. We should also remember the scale of such 243 probable interactions in terms of both the area and time, which makes it more 244 likely that the actual situation could be a combination of many such phenomena 245 occurring simultaneously at different places and times in Mesopotamia.

While there is clear evidence for a lot of Harappan activity in Mesopotamia, 248 situation back home in Indus Valley, surprisingly, was completely different. 249 According to Vidale, “(...) it soon became clear that no Mesopotamian article - for 250 example, not a single Sumerian cylinder seal - had been recovered at Mohenjo251 Daro (nor would have been found in later excavations at other Indus sites). (...) 252 On the basis of the present evidence, it is more likely that, although we have 253 ascertained that Indian groups travelled, traded and settled in the west, 254 Sumerians did not travel directly to the coasts and plains of the Indus, nor they 255 settled - at least in substantial groups - in the Indus cities" (Vidale 2004). 256 Parpola in his book "Roots of Hinduism" (2015) says that "(...) the fact that 257 hardly a single object of clearly West Asian origin has been excavated in the 258 Indus realm, makes it very unlikely that the language spoken by the 259 Harappans was any of the West Asian languages". Another important issue here 260 is that Harappans settled in Mesopotamia never came back. This situation, thus, 261 forces us to conclude that any significant Mesopotamian impact on local musical 262 traditions in Indus Valley is highly unlikely. But there can still be some (although, 
most likely very rare) musical elements from Mesopotamia that may have

264 reached Indian subcontinent. Such a find would be equally useful but the

265 identification of those elements can be very tricky as there is no support in

266 archaeology for such an occurrence. Therefore, any speculation in this regard

267 should be splendidly supported otherwise.

But such ideas were presented earlier too. Archeomusicologist Fancis W. Galpin, in his 1937 book "The Music of Sumerians and their Immediate Successors - The Babylonians and Assyrians", had drawn some parallels between Indian and Mesopotamian music and musical instruments. He even suggested the Indian

273 origin of a couple of the instruments seen in Mesopotamia. Comparing the music,

274 Galpin remarked that the musical note intervals were taken as "leaps" and

275 "slides" in very ancient sāman chant of India, as in the modern rāgās. It may have been so in Babylonia, too (pp. 64). At that time, Indus civilization was recently discovered and little was known about the depth of inter-civilizational relationship, although it was evidently clear that there were connections between them. Unfortunately, nobody worked on musical instruments in the Indus civilization and this angle of musical connections was not investigated until this study.

We shall discuss textual and archaeological records separately in what follows.

\section{Textual Evidence}

Musical instruments have a unique, albeit majorly overlooked quality i.e. when they travel to other places, many a times, their names travel with them too, just like any technical term. E.g. Violin, Guitar and especially Harmonium (which has now become an integral part of Indian music), etc. are all known with the same names in India (and the world). This is a very common phenomenon recorded

292 since ancient periods, e.g. musical terms from Sumerian are seen not only in Akkadian but also in Hittite, Egyptian, etc. as well. Therefore, if Harappan musical instruments indeed reached Mesopotamia, then it is possible that some of their 'Indian' names may also have got recorded in the text. contenders including Dravidian, Indo Aryan, Austro-Asiatic, an unknown language and also 'all of them' probably with a lingua franca. 
301 While musical tradition is not directly or specifically related to language but 302 names of instruments are. Any surviving Indian names of instruments in 303 Mesopotamian records can also give us some clues on language/s spoken by 304 Harappans.

\section{The Translators of Meluhhan Language in Mesopotamia}

Assyriologist A. Leo Oppenheim in his book "Ancient Mesopotamia: Portrait of a Dead Civilization" 1964, mentioned a Mesopotamian cylinder seal referring to an interpreter of the "Meluhhan" language, Shu-ilishu, who probably lived around 2020 BCE during the late Akkadian period. Possehl (2006) suggested that he may have been literate and could read the undeciphered Indus script.

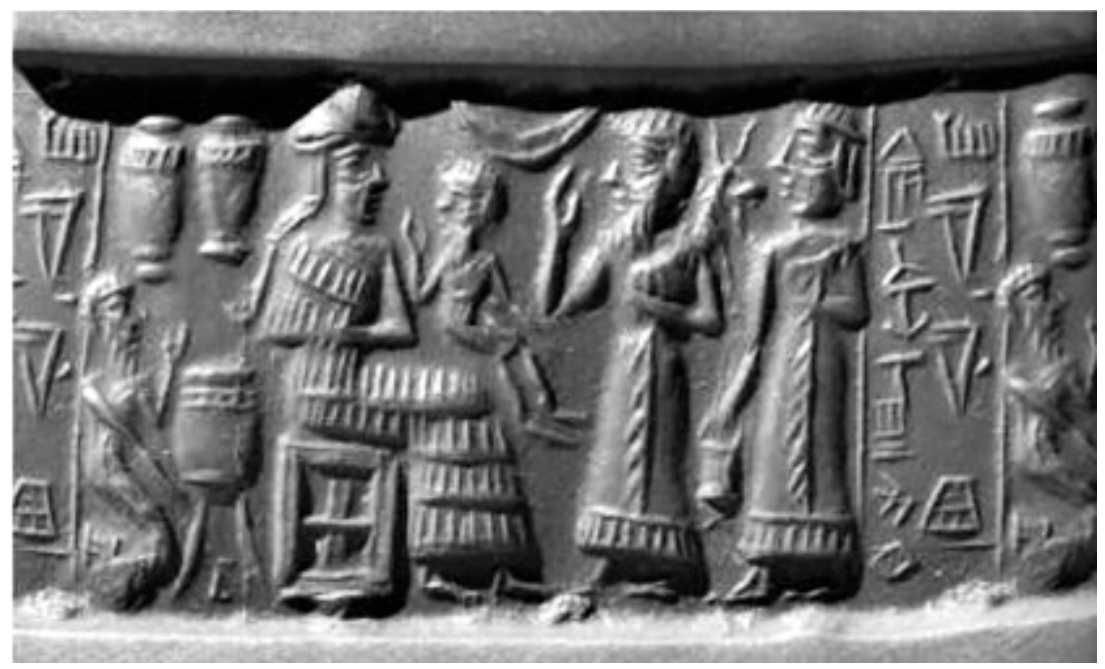

Fig. 3.1 Seal of Shu-ilishu, the Interpreter of Meluhhan Language

Fig. 3.1 shows a roll out of the seal. Iconography of the seal has a very curious thing to note: depiction of a musician playing an instrument. Musicologist Richard Dumbrill in his book "The Archaeomusicology of the Ancient Near East" (pp. 367) identified the instrument as a kettledrum placed on stand and a person sitting at far left is playing the instrument (c.f. Fig. 3.2, an example of similar tradition in India). 


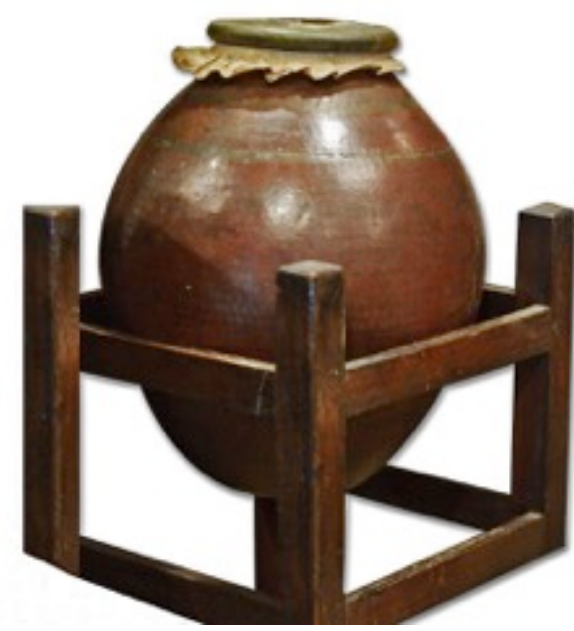

Fig. 3.2 Mizhavu, played in Koodiyattam performances in Kerala in southern India. In fact, a large variety of pot/kettle drums are found till today all over India. They are present since earliest known records, e.g. Rigveda mentions 'dundubhi', which is a kettledrum.

Specific depiction of a musician with an instrument on a seal related to an interpreter of Meluhhan language is quite intriguing and supports the assumption that Harappan traders may have brought musicians and musical instruments with them, or it may show some kind of significance of music (and animals) in relation with identity of Harappans in Mesopotamia. This appears quite probable when we see that about $50 \%$ of the Sumerian names of musical instruments and related words are quite similar to early Indian terminologies.

Sumerian (a language isolate) was chosen to be studied first (and the focus of present paper), because this was the language spoken in Mesopotamia at the time when relations between Indus and Mesopotamia started and developed. Akkadian (a Semitic language) started to spread in Mesopotamia after conquest of Sargon of Akkad around 2250 BCE (exact date is debated). Even then, Sumerian was still spoken in the region, creating a sprachbund, area of linguistic convergence (Deutscher 2007). It remained language of literature, liturgical and scientific texts. While it gradually became extinct as spoken language after 2000 BCE, as a classical language it was preserved till as late as around 200 BCE (100 AD?). Another issue is that Akkadian borrowed heavily from Sumerian. Therefore it was necessary to search for Harappan musical instruments in Sumerian first and then to extend the search in Akkadian. After all, the seal of interpreter of Meluhhan language, while from Akkadian period, still have inscriptions rendered in Sumerian.

Since, many a times, random phonetic similarities in some words can be found 
between languages, certain strict measures were used to identify a positive result:

1. Words should, not only be similar phonetically but semantically as well, i.e. they should have similar meaning too. Only occasional variations within same context were allowed, which is a natural occurrence. Such as name of an instrument in one language recorded as part of instrument in other, or name of a performance or style recorded as name of instrument etc.

2. To maintain verifiability, the phenomenon to look for is "direct word transfer". E.g. there should generally be no need to invoke proto-roots and create unattested combinations using them. This is not to suggest that such interactions may not have happened but these hypothetical occurrences were deliberately kept out from the present paper. For a nonmusical example, a person-name "which sounds Indian and may be created by combining these two roots" would not be considered as a positive result here.

3. Phonetic variations should be within the scope of the usual patterns seen in other words. A general formula for these patterns is given below.

Sumerian names of musical instruments were compared with early terms found in two major language families in India namely Indo-Aryan and Dravidian, as well as instruments from other areas, e.g. Santhāli terms. As the study commenced, some of the Sumerian terms began to show affinity to those found in early Sanskrit texts. These texts pertain to the same geographic area as that of Indus civilization. While there is a huge debate on their time periods, but at any rate, some of them are quite close temporally as well and even overlap with late Harappan period. Michael Witzel (1999) considers the early Vedic texts, since they are earlier than Dravidian texts by at least a thousand years, to be at an advantageous position of having the oldest linguistic data of the region.

Detailed list of words is given later in this text; here are just a few examples:

\begin{tabular}{|l|l|l|l|}
\hline Sanskrit & Sumerian & Sanskrit meaning & Sumerian meaning \\
\hline dịndima & dimdim & a kind of drum & a musical instrument \\
\hline mrja & meze & a kind of drum & a drum \\
\hline śarkara & šukarak & a kind of drum & a musical instrument \\
\hline vāna & bana & arched harp & arched harp \\
\hline ḍamaru & dimmaršu & a sacred drum & a musical instrument \\
\hline
\end{tabular}




\begin{tabular}{|l|l|l|l|}
\hline śamyā & šamuša & $\begin{array}{l}\text { a kind of cymbal or } \\
\text { other musical } \\
\text { instrument }\end{array}$ & a type of instrument \\
\hline mangalatūrya & malgatum & $\begin{array}{l}\text { an instrument played } \\
\text { at festivals }\end{array}$ & a musical instrument \\
\hline mrtyutūrya & miritum & $\begin{array}{l}\text { an instrument played } \\
\text { at funerals }\end{array}$ & a musical instrument \\
\hline sāyaṃtūrya & sabitum & $\begin{array}{l}\text { an instrument played } \\
\text { at evening }\end{array}$ & a musical instrument \\
\hline kinnara & nar & $\begin{array}{l}\text { a class of } \\
\text { anthropomorphic } \\
\text { musicians and } \\
\text { singers }\end{array}$ & a musician and singer \\
\hline șạ̦ja & sagida & a musical notation & a musical notation \\
\hline gada & gude & a musical instrument & a lute \\
\hline gargar & saĝara garĝar & a lute & a musical instrument \\
\hline svara & eštalu & a musical notation & a musical notation \\
\hline stavitṛ & gala & a praiser, singer & a type of singer \\
\hline gatr/gala & $\begin{array}{l}\text { a singer/a musical } \\
\text { instrument and } \\
\text { throat }\end{array}$ & lamentation singer \\
\hline
\end{tabular}

There are about 60 words in total in Pennsylvania Sumerian dictionary that are related to music, particularly in categories like singers, musical instruments, musical notation, songs, etc. Out of which some 30 words are found to be very similar to Sanskrit phonetically as well as semantically but with an apparent "Sumerianization", as evident in examples given above.

Interestingly, many similar instruments are found in the southern region of India as well, where the Dravidian languages are primarily spoken today and similar cultural symbolism can also be seen in their designs. But the Dravidian names of instruments did not show resemblance to Sumerian names, except for just a couple of terms, which too seem to be of Sanskrit origin. In fact, there are many terms of Sanskrit origin in south Indian musical spheres. Another clinching evidence comes from a study of musical scales. There are some seven scales mentioned by Anne Kilmer that are recorded in Mesopotamia; all of which are 403 heptatonic (having seven notes) (Kilmer 1998) and are descending in order 404 (Dumbrill 2017). Earliest known scale from north India is of Sāmveda, which too 405 is heptatonic and descending; and importantly, it is similar to one of those seven 406 recorded in Mesopotamia. Whereas, scales in early Dravidian texts are pentatonic 407 (having five notes) and only later heptatonic scales enter Dravidian music. 
409 But the curious part is the "Sumerianization" seen in most cases. Which is, in a 410 way, seems similar to "Phono-Semantic Matching".

\section{Phono-Semantic Matching}

414 Phono-semantic matching (PSM) is the incorporation of a word into one 415 language from another, often creating a neologism, where the word's non-native 416 quality is hidden by replacing it with phonetically and semantically similar 417 words or roots from the adopting language. Thus, the approximate sound and 418 meaning of the original expression in the source language are preserved, though 419 the new expression (the PSM) in the target language may sound native. (See 420 Zuckermann 2003a, 2003b, 2004, 2006, 2009)

422 One of the Sumerian text (from Sargonic period) records that Lu-sunzida "a man 423 of Meluhha" paid to the servant Urur, son of Amar lu KU, 10 shekels of silver as a 424 payment for a tooth broken in a clash. The original text is as follows:

425

BM 86314 = E. Sollberger, CT 5o (I972) no. 76.

428 Obv.

429 1.10 gin kug

$430 \quad 2$ kug zu gul-la-kam

4313 ur-ur ni-is-ku

4324 dumu amar-lu-ku 4

4335 lu-sun-zi-da

4346 lu me-luh-ha-ke

4357 i-na-ab-su-su

437 Rev.

4388 lugal-iti-da

4399 maskim

44010 ugula EN-ilu

442 The name Lu-sunzida literally means "Man of the just buffalo cow," a name that, 443 although rendered in Sumerian, according to the authors (Parpola et al. 1977), 444 does not make sense in the Mesopotamian cultural sphere and must be a 445 translation of an Indian name (Vidale 2004). Another similar example is found on 446 an Indus style seal with Sumerian inscription from 2500 BCE. (Aruz \& Wallenfels 
448 p.280, fig.111; Woolley 1956a p.174). The inscription on the seal is believed to be 449 an Indian name translated to Sumerian (either SAG.KU(?).IGI.X or 450 SAG.KU(?).P[AD](?)). Unfortunately, in both the cases, we don't know their 451 original Indian forms; therefore it cannot be verified that whether or not these 452 names had any phonetic similarity to their respective origin. But this is not the 453 situation with the names of musical instruments and other words that are found 454 in this study, as corresponding Indian words are known.

Curiously, a comparative study demonstrated certain patterns in the way words were sumerianized in terms of handling of phonemes and word structures that are not compatible with Sumerian. Some part of it could be a necessity to make them expressible in the Cuneiform script.

Sanskrit has 33 consonants, 11 vowels (14 in Vedic variety), whereas Sumerian has only 16-18 consonants and 4 vowels (Sumerian is still not understood well and there is a debate on their exact number of consonants and vowels and their phonetic values). There are other inherent limitations too, like no word in Sumerian can have two or more consecutive consonants in the beginning or at the end of the word and not more than two anywhere in the word (mostly at the intersection where morphemes join). This is not the case with Sanskrit, which uses clusters of half syllables (consonants with no power or vowel attached to it) as well as many compounds like tr. pr, etc. Let us call them "non-compatibles" here, some examples are mentioned with the list of words.

Close study of musical terms suggested some consistency in process of sumerianization, which was evident in majority of cases. It can be loosely understood in general as:

Sanskrit word $\rightarrow$ Removal of non-compatibles $\rightarrow$ Replacement with closest Sumerian phoneme/morpheme/root/word $\rightarrow$ Final word rendered in Sumerian were also observed in some examples (mentioned with the associated words in 
Sum. = Sumerian (Period of attestation is given with the words wherever possible) Akk. = Akkadian (while Sumerian is point of discussion here but Akkadian terms are given wherever possible) wr. = written as

(1) Sans. dindima डिण्डिम a kind of drum. This instrument is played till today in India, known as dimdi.

(3) Sans. śarkara शर्कर, a kind of drum ṇ (ण) is a non-compatible, rest of the word remains the same. In Sanskrit, there are many similar names of instruments like dundubhi, dardura, dardara, bhambha, etc. as found in the Rigveda and later texts, showing a continuing tradition of such names.

(2) Sans. mrja मृज a kind of drum (lex., mrj root RV, AV) Sum. meze a drum (3x: Old Babylonian) wr. me-ze 2 ; meze; mezem?

(4) Sans. sālikā सालिका a kind of flute Sum. SALI a musical instrument wr. SA.LI Akk. Pagû 
and in later IA languages as well, e.g. bhumi-bhumika, jeev-jeevika, etc. Alternatively, removal of ' $k \bar{a}$ ' could be an example of clipping, a.k.a. "truncation" or "shortening"; in this particular case apocope, i.e. the loss of one or more sounds from the end of a word. Clipping is seen in many other examples as here. There are no non-compatibles, hence, no change in the word otherwise.

(5) Sans. vāṇa/bāṇa arched harp, arrow (Rigveda), a harp with 100 strings (Taittirìya Saṃhitā, Brāhmṇa, Śrauta Sūtra) Sum. bana/pana/ban arched harp; bow; a geometric figure (63x: ED IIIb, Old Akkadian, Lagash II, Ur III, Early Old Babylonian, Old Babylonian) wr. gešpana; ba-na; ĝššpanax $(|S ̌ E . N U N \& N U N|)$ Akk. qaštu

Both the syllables are non-compatible, but such isoglosses are commonly seen. Similar variations of the word are found in Indian musical sphere too like Bānam and Pena (both instruments played using a bow). A sign in Harappan script is clearly derived from a multi-stringed arched harp (Sachs 1944) (sign no. 311 Mahadevan 1977). Indus script possibly had its roots in about 3500 BCE and was fully formed by 2800 BCE (Kenoyer, 2006b). Their presence in script suggests that they were already popular by then. Therefore, it is highly likely that multi stringed arched harps were present in Indus culture at least (well) before 2800 BCE. It is also an important instrument in vedic literature, in Rigveda and others. Taittirīya Samhitā mentions it as an instrument with 100 strings. A simple single stringed 'harp' i.e. 'musical bow' is basically a bow in construction with a simple resonator e.g. human mouth, any pot with bow resting on it while playing, a gourd, etc. Men probably had bows long before 3500 BCE (13000 BCE?). Adding one more string is very easy and in a way, an obvious next step. So it is not improbable for harps to have evolved into simple multi stringed variety (e.g. 2 or 3 strings) relatively early after people had realized musical use of a bow. Harps continued and remained popular in India till as late as second half of $1^{\text {st }}$ millennia $\mathrm{AD}$, after which they faded away.

Vâna appears to be an onomatopoeic word, which represents sound of the string of bow or bow-shaped harp. Phonetic quality of the second syllable $n$ is very close to sound of resonance of a vibrating string that is heard after the initial attack of the sound. Fig. 4 shows volume envelope curve (ADSR) of a sound waveform. This phenomenon can be easily experienced by 
vocalizing or mimicking sound of any stringed instrument that decays quickly i.e. which do not have long or continuous sound like a violin. E.g. a musical bow, but any similar sound would suffice for the purpose. When we try to vocally mimic sound of a vibrating string, a component of a nasal / $n$ / like sound is mostly present there in combination with other sounds depending on timber of instrument being mimicked.

566

567

568

569

570

571

572

573

574

575

576

577

578

579

580

581

582

583

584

585

586

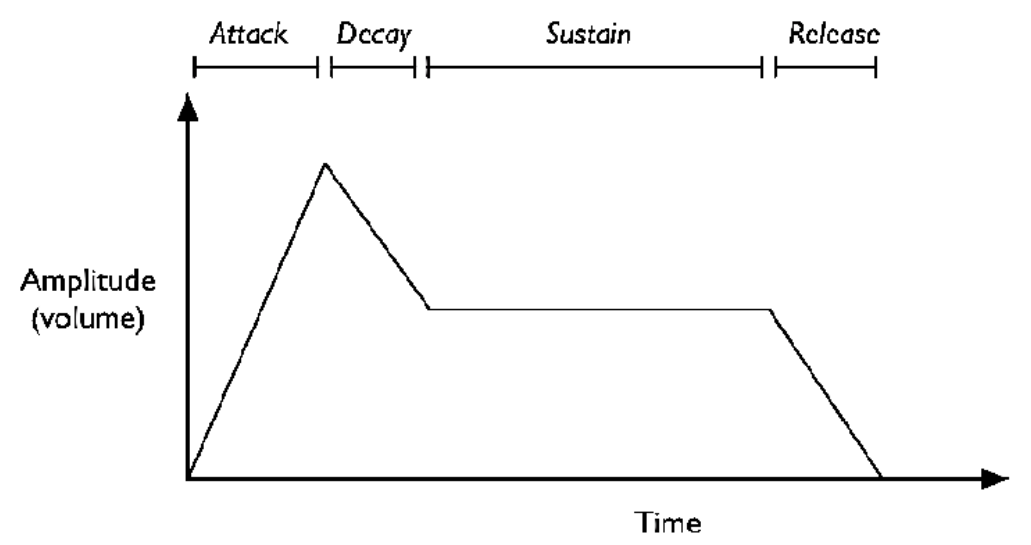

Fig. 4 Volume envelope curve (Attack-Decay-Sustain-Release) of a sound waveform

In the Vedic literature, another meaning of vāna (or bāna) is 'arrow'. This is interesting; as a similar sound would be produced by the action of shooting an arrow. Hollow and airy quality of $/ v /$ could be a representation of whizz of arrow and $/ n /$ of the sound of the string vibrating after that. This suggests a possibility that origin of this word could be very old, expressed in the root van ( $\sqrt{\text { वण्) }}$, to sound. Thus, Vāna could be what produces that sound whether it's an arrow or the bow itself in the form of a harp. There are many other words found in Sanskrit text which clearly indicate its relation to sound, such as:

vana वण sound, noise

vāṇī वाणी sound, voice, music (plural a choir of musicians or singers)

$\boldsymbol{v} \bar{i} n \bar{a}$ - A generic term for the category of stringed instruments. Also used as suffix with any instrument that is stringed, to denote its nature. E.g. Kachhapi vīnā, Rudra vịnā, etc. In other words, viṇā could be any instrument that produces the sound by means of vibrating string. It appears in Taittirīya Saṃhitā and Atharva veda and remains highly popular till today. It is possible that vin̄a is an invented term, coined colloquially most probably by musicians (and not grammarians).

kvana क्रण the sound or tone of any musical instrument 
dhvan ध्वण् to sound

Interestingly, in both the above example (kvaṇa, dhvan) different phonemes are added in the beginning of the word. As explained above, this could be due to different characters of the sounds these words may be representing. E.g. kvana, with its strong attack section, could be inspired from sound of a string instrument played with a plectrum, which would naturally have stronger attack than something played with fingers. C.f. kvanit to vibrate.

śravaṇa श्रवण the act of hearing śatapatha brāhmaṇa, mahābhārata, etc. vānaśabda वाणशब्द the sound of a lute, the whizz of an arrow (here the connection is with lute instead of harp along with arrow, which may suggest that its not about a particular instrument but the sound of it).

While arched harp exists in Dravidian records too but the Dravidian word for it, 'vil' or 'vil yazh', does not match as closely with the Sumerian word.

603

In the context of Indo-European languages, the word vāna is exclusive to 608 India. It is part of those about 300 words from Rigveda listed by Kuiper $(1955,1991)$ and proposed to be part of 'Harappan' language by some (Witzel 2001(?)).

(6) Sans. gargara गर्गर a kind of musical instrument (Rigveda viii , 69, 9) (possibly a lute)

Sum. harhar/ĝarĝar a musical instrument (31x: Ur III) wr. gešhar-har

(7) Sans. sara सर a cord, string (c.f. sans. trisarī त्रिसरी Name of a stringed instrument having three strings)

Sum. sa string (of a bow, musical instrument), gut, sinew, tendon, catgut string (68x: Old Babylonian) wr. sa Akk. dāmu; erru; matnu; pitnu It could be result of clipping seen in many example here. Attestation is late in Mesopotamia and there are older words with similar meaning. $S \bar{a}$ is also an abbreviation for the first note in Indian scales.

\section{(8) Sans. Stavitṛ स्तवितृ a praiser, singer, Maitrāyaṇī Saṃhitā}


Sum. eštalu a type of singer (2x: Old Babylonian) wr. ešs-ta-lu 2 ; aš-ta-lu 2 Akk. aštalû

Sanskrit word is pronounced as istavitr. -vitr is clearly a non-compatible. Word seems to have entered in Akkadian period as attestation is late and word is very similar in both Sumerian and Akkadian.

(9) Sans. gātr गातृ a singer

Sans. gala an instrument; throat; also gai singer

Sum. gala singer, lamentation singer (500x: ED IIIb, Old Akkadian, Lagash II, Ur III, Old Babylonian) wr. gala; gala 10 Akk. kalû

(10) Sans. Svara musical notation (Rigveda)

Sum. saĝara a musical notation (54x: Old Babylonian) wr. sa-gar-ra 'sva' is non-compatible.

(11) Sans. șadja षड्ज A musical notation, an ancient musical scale (one of the three ancient intonation schemes i.e. grama) Nārdiya Sikshā, Nātyaśāstra, etc.

Sum. sagida a musical notation; a musical instrument (59x: Old Babylonian) wr. sa-gid 2 -da Akk. sagiddû

'dja' is non-compatible.

(12) Sans. godhā गोधा a chord; a musical instrument - possibly a lute (Griffith, Roth, Hillebrandt etc.) (Rigveda viii, 58, 9). Sans. godhāvīnā $\mathbf{k a ̄}$ गोधावीणाका a kind of stringed instrument (Kātyāyana Śrauta Sūtra xiii, 3, 17) (the term godhāvinnākā would generally mean "a vịnā i.e. stringed instrument named godhä $\left.{ }^{\prime}\right)$. Also Sans. gada गद name of a musical instrument, and Sans. guna गुण the string of a musical instrument, chord

Sum. gude lute (1x: Old Babylonian) wr. gu, $\mathrm{de}_{2}$

Non-compatible ' $o$ ' and ' $d h \bar{a}$ '. It is seen in many examples here that 'o' is seemingly replaced by other vowels. 
660 (13) Sans. damaru डमरु a sacred drum shaped like an hourglass, used by the God śiva

Sum. dimmaršu an instrument (1x: Old Babylonian) wr. gešsim 3 -mar-šu

663

664

665

666

667

668

669

670

671

672

673

674

675

676

677

678

679

680

681

682

683

684

685

686

687

688

689

690

691

692

693

694

Fancis Galpin (1937) had suggested that damaru may have originated in Indus Valley. There is a signs in Indus script that appears quite similar to it (sign no. 214 and its variations, Mahadevan 1977). Damaru is the instrument of śiva in Hinduism, the originator of music. Hourglass drums are played till today in sumptuous varieties throughout India, which supports its ancient Indian origin as suggested by Galpin and others.

(14) Sans. ghus घुष् to sound; to cry or proclaim aloud, call out, announce publicly, declare, etc. (Rigveda, Mahabharat, etc.)

Sans. ghosa घोष The sound of a drum (or any musical instrument), of a conch-shell, of the soma stones, of a carriage, etc. Rigveda, Atharvaveda, etc. Sans. ghosavatī घोषवती a peculiar kind of stringed instrument

Sum. guš a musical instrument?; a part of a musical instrument? (1x: Old Babylonian) wr. ĝešguz-uš

Although exact meaning is not clear in Sumerian but relation to music is apparent. Only comes in a praise poem of Culgi. (ĝišgu $\mathrm{gu}_{2}-\mathrm{uš} \mathrm{za-mi} 2$-a kam-ma

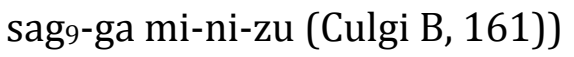

(15) Sans. śamyā शम्या a kind of cymbal or other musical instrument

Sum. šamuša type of instrument? (1x: Old Babylonian) wr. ša-mu-ša4

' $\mathrm{y}$ ' is non-compatible.

(16) Sans. kamrā कम्रा a kind of musical instrument

Sum. kamma a part of a musical instrument?; tuning? (2x: Ur III, Old Babylonian) wr. kam-ma

(17) Sans. mrtyutūrya मृत्युतूर्य a kind of drum beaten at funeral ceremonies Sum. miritum a musical instrument (4x: Old Babylonian) wr. mi-ri 2 -tum 
Very difficult word from Sumerian perspective with many non-compatibles like consonant cluster in the bigining 'mrty', as well as ending 'tūrya' . There is a particular pattern is seen in many examples here in use of 'tum' (or lum/hum, etc.) as a replacement for such non-compatible parts at the end of the word.

701

702

(18) Sans. sāyaṃtūrya सायंतूर्य instrument played in evening Sum. sabitum a musical instrument (5x: Ur III, Old Babylonian) wr. gešsabi $i_{2}$-tum; sa-bi 2 -tum

(19) Sans. mañgalatūrya मड़गलतूर्य a musical instrument used at festivals Sum. malgatum a musical instrument; a type of song (5x: Old Babylonian)

(20) Sans. ädambara आडम्बर a kind of drum Sum. adab a drum; a song (42x: Old Babylonian) wr. a-da-ab; a-da-ba Akk. adapu

(22) Sans. kroda क्रोड an additional verse or note, a notation earlier in sālikā/SALI and other words.

(21) Sans. śabdaviśeșa शब्दविशेष a particular note, the varieties of sound (these the sāṃkhya- arranges according to the accents, udātta-, an-udātta-, svarita-, and the notes of the gamut, șaḍ-ja-, rṣabha-, gāndhāra-, madhyama-, pañcama-, daivata-, nișāda-, etc.) 
(23) Sans. karatāla करताल beating time by clapping the hands, clapper, small cymbals, clappers with cymbals, etc. Kara (RV)+ Tāl (Tal root (RV)) Nardiya Shiksha, bhāgavata-purāṇa Akkadian. Katral small cymbles?, clapper? Galpin (1937), Sachs (1940) karatāla is made from combining kara i.e. hand (Rigveda) and tāla i.e. rhythm (Naradiya Shiksha, root tal, present in Rigveda). Galpin (1937) connected the Akkadian word 'katral' to small cymbal and suggested its origin from Indian word 'karatāla'. But Curt Sachs in "History of Musical Instruments" (1940) identifies Indian karatāla with clappers and so he disagrees with Galpin's identification of the instrument but he agrees that "the Akkadian term ought to be taken from it (Indian term karatāla) and transformed by metathesis". This confusion about exact meaning is easily understandable if one looks at the vast tradition of karatāla-s all over the subcontinent. It is one of most popular percussion instrument in folk, temple related and classical music in some form or other. Sage Narada, the celestial musician of highest regard in Sanskrit texts, is always depicted with a viṇa and a karatāla. There are innumerable varieties of karatāla-s found in India since ancient times ranging from two simple pieces of wood or small cymbals to highly decorated or zoomorphic clappers with jingles/small-cymbals and/or small metallic rattles attached to them. Usage of the word is same all over India including Dravidian speaking south. The word karatāla represent a family of instruments, which sound somewhat like handclap and perform a similar function in music i.e. of keeping time. There is a sign in Indus script (sign no. 294 Mahadevan 1977) similar to the clappers seen in Mesopotamian iconography, being played by anthropomorphic musicians (discussed in detail in the section of Archaeological Evidence). Although it is a simple shape but as arched harp and damaru are seemingly represented in the indus script, it becomes tenable that there could be a few more script signs inspired by musical instruments, at least the most popular ones.

(24) Sans. sindhu सिन्धु a rāga in Indian classical music (a rāga is a melodic framework based on which many compositions/songs can be performed) sindhu bhairavi सिन्धु भैरवी a rāga sindhi bhairavi सिन्धी भैरवी a rāga Sindh सिन्ध a rāga 
sindhurā सिन्धुरा a rāga

sindhurā bhairavi सिन्धुरा भैरवी a rāga

Sans. sindhu सिन्धु the name of the river Indus

Sum. endu a song (76x: Lagash II, Ur III, Old Babylonian) wr. en 3 -du; en-du Sum. enduana a song (1x: Old Babylonian) wr. en 3 -du-an-na

Sum. enduĝarĝar composer (1x: Old Babylonian) wr. en 3 -du-ĝar-ĝar Importantly, gargara is an instrument mentioned in Rigveda.

Sum. endudugdug chanter? (1x: Old Babylonian) wr. en 3 -du-dug ${ }_{4}-\mathrm{dug}_{4}$

Despite similar names, they are different rāga-s. Many of them are present in both Hindustani (northern) and Carnatic (southern) classical music and existent as important part in long standing folk traditions of Rajasthan, Sindh, Gujarat and Panjab. Sans. sindhu सिन्धु is the name of the river Indus; it has been used in identification of geography, populace and cultures of Indian subcontinent (or part of it) by outsiders throughout later historic period and from which India got its names (more on that later with word no. 55 Sum. hindum, beads).

(25) Sans. Iāsya लास्य dancing, a dance (especially accompanied with instrumental music and singing), a dance representing the emotions of love dramatically (this was at one time a principal part of the drama), including also a style of dramatic composition in which there is abrupt transition from Sanskrit to Prakrit and from Prakrit to Sanskrit; the term lāsya is also applied to the Nach [Nautch] dance of the Indian dancing girls, consisting chiefly of gesticulation with a shuffling movement of the feet forwards and backwards, as invented by pārvati (wife of śiva) and opposed to the boisterous masculine dance called tāṇạa practiced by śiva and his followers (Mahābhārata, Nātyaśāstra, etc.) Also Sans. Ias लस् to sound, resound; to play, sport, frolic; to embrace; to dance; to cause to teach to 800 
Sum. lilis a musical instrument, kettledrum (8x: Old Babylonian) wr. li-liis 3 ; li-li-is ${ }^{2 a b a r}$; li-li-is2; liliz Akk. lilisu

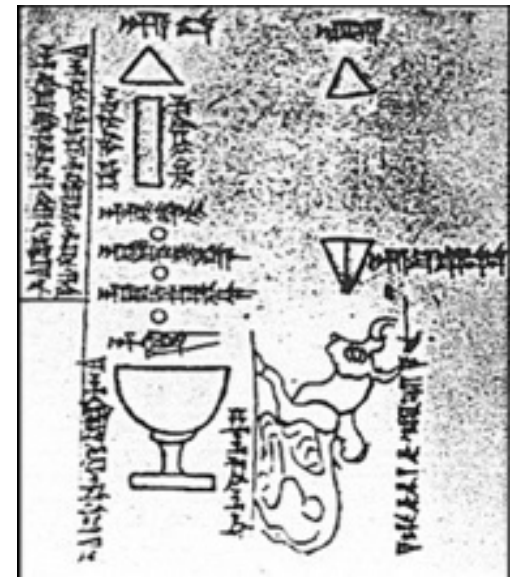

Fig. 5: Lilis

Lilis seems most likely of Indus origin because the tablet on which its drawing and name is present (Fig.5), also has a humped bull shown on it, which is native to south Asia only. The bull is sitting in a calm position similar to how it is represented heavily in siva-'s temples in India. On the other hand, lāsya is related to pārvati, wife of śiva.

(26) Sans. bhāṇ̣a भाण्ड a musical instrument, any pot (especially metallic) implement, tool, instrument (root bhan, to sound, most probably onomatopoeic, has resemblance to the sound of metallic object/pot struck loudly.)

Sans. bhānda भाण्ड a class of folk musicians, performers and entertainers. Later became a cast. Also known for using disguises during performances, also a jester, buffoon, mime

Sans. bhānda भाण्ड a form/school of drama and performance; can also mean mimicry, buffoonery. C.f. bhāṇa भाण name of a sort of dramatic entertainment (in which only one of the interlocutors appears on the scene, or a narrative of some intrigue told either by the hero or a third person)

Sans. bhandila भण्डिल an artisan

Sum. bala $\hat{g}$ a large drum or harp (154x: ED IIIa, ED IIIb, Old Akkadian, Lagash II, Ur III, Early Old Babylonian, Old Babylonian) wr. balaĝ; ĝšsbalaĝ Akk. balangu

Sum. bala $\hat{g}$ temple functionary or servant Gods, associated with variety of instruments (Wolfgang Heimpel, Franklin John Curtis 2016)

Sum. balaĝil musician (1x: Old Babylonian) wr. balaĝ-il 2

bh>b is easy, 'nda' is non-compatible. There is a similar example in category of 'Other Words' below, sans. śand $\hat{g} \hat{g} a$. Whereas in this case, instead of bhānda to something like bâĝa a ' 'la' 

is also present between $b a$ and $\hat{g}$. A deeper study revealed that there is no word in Sumerian (PSD) that starts with $b a$ followed by $\hat{g}$, effectively rendering ba- $\hat{g}$ combination, a non-compatible. Ba-la combination, on the other hand, is present in many other words.

bhāṇt-s are a class of traditional folk entertainers of India. In later time it became a cast. According to Henry Miers Elliot (Supplement to the glossary of Indian terms, N.H. Longden, 1845), “(...) Those also are called Bahand (bhānda) who without reference to caste follow the occupation of singing, dancing, and assuming disguises (...)"

Today bhānd -s are present in Uattar Pradesh, Kashmir, Panjab, etc. in India. While most present day bhānd -s belong to families that are/were engaged in folk entertainment as their hereditary profession, their specific art forms vary greatly by region, community and language. The term bhānd can also mean a specific dramatic story or an entire form/school of drama.

(27) Sans. Svara sound of any musical instrument or singer; music; notation, etc. (Rigveda)

Sum. sur plectrum?; a musical instrument? (1x: Old Babylonian) wr. ĝešsur, Akk. zannaru

Exactly same variation (sur) is present in many later Indian languages as well. Exact meaning is not clear in Sumerian.

(28) Sans. vidūṣaka विदूषक a jester, wag, buffoon (especially in dramatic language) (Bhagvata Purana, etc.)

Sum. uddatuš jester (40x: ED IIIb, Ur III, Old Babylonian) wr. ud-da-tuš

Apart from non-compatible beginning ' $v i-$ ', there is no Sumerian word (PSD) that ends with '-saka'. Sans. vidūṣaka is mentioned as "the jocose companion and confidential friend of the hero of a play (he acts the same confidential part towards the king or hero, that her female companions do towards the heroine; his business is to excite mirth in person and attire, and to make himself the universal butt; a curious regulation requires him to be a Brahman, or higher in caste than the king himself)" (Monier William Sanskrit dictionary). 
(29) Sans. kinnara (kimnara pronounced kinnara) किंनर kim+nara literally "is it a man?" "whether a man?" "what sort of a man?"; anthropomorphic mythical beings with a human figure with animal head or animal figure with human head, usually horse or bird but may be others too; reckoned among the gandharva-s or celestial choristers and celebrated as musicians; also attached to the service of kubera; a class of traditional musicians and performers known for their use of animal costumes and disguises, similar traditions still continue in small pockets; in Jainism, one of the eight orders of the vyantara-s

$$
\text { Sans. kinnarā किंनरा a kind of musical instrument }
$$

Sans. kinnari a lute, also a female kinnara

kinnaur - name of a present day district in northern state of Himachal Pradesh in India.

Sum. nar musician; singer (643x: ED IIIa, ED IIIb, Ebla, Old Akkadian, Lagash II, Ur III, Early Old Babylonian, Old Babylonian) wr. nar Akk. kinnāru a lyre

Akk. nāru a musician and singer

Akk. nārē a band of lyre and harp players

Egyptian. $\boldsymbol{k n \boldsymbol { r }}$ a lyre

Hittite. Kinir a lyre

\section{Hurrian. kinnar uhuli a lyre player}

Hebrew. kinnor a lyre

The cuneiform sign for Sumerian 'nar' is derived from a pictogram of an animal head (Cheng 2009). Similarly, kinnara-s in Sanskrit records, are often depicted with animal heads or as part human and part animal/bird. There is a remarkable tradition of mixing animal and human attributes recorded in Harappan archaeology and in later periods in south Asian cultures; (more on that later in the section of archaeological records). This word seems to follow the pattern of "clipping" as found in some other words, in this particular case, "initial clipping", "apheresis" or "procope". Initial clipping retains the final part of the word, e.g. phone (telephone), net (Internet), gator (alligator), varsity (university), etc. Other similar example here is Sans. romaś/lomaś $\rightarrow$ Sum. maš, a goat (see below). But curiously, in 
both the cases, the removed first syllable is also accompanied with a noncompatible, i.e. vowel 'o' in romash and anusvāra with 'ki' in kimnara, expressed as a dot in devanāgri script as किं and transliterated as $m$. Pronunciation of anusvāra depends on the sound that follows. In kinnara, it is pronounced as the first ' $n$ '. Sans. Kimnar is not a word but actually a sentence with a question mark in it "kim nara?" meaning "what sort of a man?" or "is this a man?" etc. (in a way, expressed as "What! man?"). It encapsulates the expression of an astounded observer. Both 'kim' and 'nara' are Rigvedic words. Apart from the popular clipped version, i.e. Sum. 'nar' or Akk. nāru, etc., the word is duly present in its entirety as well in names of instruments and as musicians in Mesopotamia and surrounding region in many languages like Akkadian, Hittite, Egyptian, etc. and remained popular till later, e.g. attested in Hibrew Bible as kinnor, a lyre. Parpola (2010) confirms with help of Assyriologists that its word structure doesn't match with west Asian languages and is clearly of south Asian origin.

(30) Sans. ājakāra आजकार śiva-'s bull Sum. alĝar a musical instrument, bull lyre (Galpin 1937, Dumbrill 2005,

A detailed comparison of the tradition of anthropomorphic musicians in both the cultures is given below in the section of archaeological records. Cheng 2009, etc.) (12x: Old Babylonian) wr. ĝešal-ĝar; al-gar Akk. Alû

' $\mathrm{j}$ ' is non-compatible. $\mathrm{k}>\mathrm{g} / \mathrm{g}$ is seen in other examples here but it is also present in Sanskrit itself e.g. abhikara/abhigara (a priest). ājakāra to alĝar, not only fits well according to the formula but also, importantly, to the traditions of naming instruments in India, (discussed below). An instrument named 'algojā' is still found in folk music of modern day Panjab, Rajasthan and Sindh (all of which are home to many important Harappan sites), although it is not a stringed instrument anymore but a pair of reed flutes.

Siva is considered to be the originator and supreme God of music and there are many terms in south Asian musical spheres that are related to him or to the concepts associated with him, which include names of instruments, raga-s (scales), tāla-s (rhythmic meters), dance forms, poetic meters and more (see damaru and lāsya above). In later periods, in India, word nandi is 
attested as śiva's close aid and his bull (actually a bull-calf). Consequently, in Mahābharta and sutrā literature of late vedic period, bull-shaped instrument too gets the moniker 'Nandi', mentioned as an instrument played on happy occasions. Nandi as instrument is attested later in Harivamsh as well, after which it doesn't seem to be mentioned anywhere. But many other instruments associated with Śiva (e.g. rudri/rudra viṇā, damaru, etc.) and rāga-s, tāla-s, etc. continues till today. instruments are mostly found to be auto-logical or self-describing and sometimes onomatopoeic (representing sound of the instrument). Thus, names mostly give additional information about the instruments. While concentration of this discussion is on Sanskrit but similar practices are found in all language families in India, which is in a way, remarkable.

A. Sometimes they describe shape of the instrument like Kachchapi - a lute shaped as tortoise or Kachchapa; Mayuri - a lute shaped like peocock or Mayura, Gomukha - an instrument with cow/bull face, Nandi - an instrument shaped like bull, etc. There are many such examples mentioned later. If it is a stringed instrument of any kind then some times word "vīna" is suffixed with names to denote that.

B. Material used in manufacture like Vamsha - a flute made from vamsha i.e. bamboo; Mridang - a horizontal drum played from both sides, made from Mrida i.e. clay; Tumbi vīna - a lute which has a tumbi i.e. a gourd used as a soundbox.

While all of these musical terms are fully verifiable in both the languages but it

C. Sound of instrument - Dindima, Gubguba, Tuntuna, Vāṇa, etc.

D. Number of strings in the instrument like Ektantri, Dotārā, Sapta tantri, etc.

E. Based on name of the person/deity they belong like Rudri/Rudra-vinna $\bar{a}$, Saraswati vīnā, Rāvan-Hast, instruments related to Śiva, Saraswati and Rāvana of Rāmayan respectively; Tumburu viṇā, the vịnā of a celestial anthropomorphic musician Tumburu) and Kinnari/Kinnarā/Kinnaram, instruments related to Kinnara-s. 
990 cultural impact this list suggests, then there must be more words in Sumerian

991 records pertaining to the other fields and activities for which there is direct or 992 indirect evidence for Harappan involvement of some kind, belonging to same 993 underlying language as that of musical terms (i.e. Sanskrit) and also exhibit 994 similar patterns in the process of sumerianization.

995

996 Below is a list of terms found in other areas. Same strict measures were 997 employed to identify a positive result as mentioned earlier along with an added 998 condition that it should be related to the fields or activities that can be linked to 999 Harappans or south Asia in some way.

1000

1001

\section{Trade and Craft Related Words}

1003

\section{Units of Measurement}

1005

Harappan style weights have been found not only in Mesopotamia but also in Bahrain, Oman, etc. in archaeological records. The same appears to have reflected in the Sumerian text as well:

(31) Sans. māna मान a particular measure or weight (equals krșnata-or raktikā-; according to scholiast or commentator on TS and KSS 100 māna-s = 5 panas or pala-s) Taittirīya Saṃhita, Kātyāyana Śrauta Sūtra II, Ur III, Early Old Babylonian, Old Babylonian) wr. ma-na Akk. manû

(32) Sans. pana unit of weight, coin, share in gambling, a trading community in Rigveda Babylonian) wr. ba-an; $\operatorname{ban}_{2}$; ban 3 ; ba-an-AŠ; dugban 3 Akk. sūtu

As seen earlier $\eta$ becomes $n$. $\mathrm{p} / \mathrm{b}$ isogloss is anyways seen a lot. 
1027

1028

1029

1030

1031

1032

1033

1034

1035

1036

1037

1038

1039

1040

1041

1042

1043

1044

1045

1046

1047

1048

1049

1050

1051

1052

1053

1054

1055

1056

1057

1058

1059

1060

1061

1062
(33) Sans. Kola कोल the weight of one tola- (= 2 țan̉ka-[or śāṇa]= 1/2 karṣa-

Sum. kila weight (2450x: ED IIIb, Old Akkadian, Lagash II, Ur III, Early Old Babylonian, Old Babylonian) wr. ki-la 2 Akk. šuqultu

"o" is non-compatible.

(34) Sans. agra/agrā अग्र/अग्रा a measure of food given as alms/ measure of amplitude (Surya Siddhānt) (the distance from the extremity of the gnomon-shadow to the line of the equinoctial shadow)

Sum. âg measure ; to measure (219x: ED IIIb, Old Akkadian, Ur III, Early Old Babylonian, Old Babylonian) wr. ag $\hat{g}_{2}$ Akk. Madādu

(35) Sans. bhāra भार a burden, load, weight (Rigveda), a particular weight $(=20$ tulā-s = 2000 pala-s of gold)

Sans. bhara भर in full measure, a large quantity, great number, mass, bulk, multitude, abundance, excess, etc., with all one's might, a burden, load, weight and also a particular measure of weight equals bhära

Sum. bur unit; a unit of area; a unit of volume (123x: ED IIIb, Old Akkadian, Ur III, Old Babylonian) wr. bur; bur, Akk. Būru

(36) Sans. drona द्रोण a measure for measuring fields (as much land as is sown with a drona of corn), a measure of capacity ( $=4$ a ḍhaka-s $=16$ puṣkala-s $=$ 128 kuñci-s $=1024$ musți-s, or $=200$ pala $-\mathrm{s}=1 / 20$ kumbha - , or $=1 / 16$ kharī- $=4$ ā ḍhaka-s, or $=2$ ā wooden vessel, bucket, trough, etc. (Rigveda, Mahābhārata, Lex)

Sum. dana a unit of length, double-hour (distance), double-mile (54x: ED IIIb, Old Akkadian, Ur III, Old Babylonian) wr. da-na; danna; dana2 Akk. bêru

The combination ' $d r$ ', 'o' and ' $n$ ' are non-compatibles.

(37) Sans. goṇī गोणी a weight measure of 4 droṇa-s, still used in India.

Sum. gun load; yield; a unit of weight; rent, tax, tribute; (5551x: ED IIIb, Old Akkadian, Lagash II, Ur III, Early Old Babylonian, Old Babylonian, Middle Babylonian) wr. gun 2 ; gu2-un Akk. biltu 
(38) Sans. īṣā ईषा a particular measure (Sulbha Sūtra) Sum. eše area unit; a unit of length (2x: Old Babylonian) wr. eše 3 ; eše $e_{2}$ "a unit of area; a unit of volume" Akk. eblu, also Akk. aslu

(39) Sans. krośa क्रोश a measure of distance, commonly called a kos $=1000$ daṇda-s $=4000$ hasta-s = 1/4 yojana-; according to others = 2000 daṇ̣a-s $=$ 8000 hasta-s = 1/2 gavyūti-) Kātyāyana Śrauta Sūtra, Mahābhārat, etc.

(40) Sans. guru गुरु heavy, weighty (Rigveda i, 39, 3 and iv, 5, 6; Atharva veda), large, valuable, highly prized

It is striking that all the words (except one) related to units/measures are well. 


\section{Trees/Woods, Wooden Furniture and Related Words}

As quoted earlier, trees/woods, timber for construction, ships and wooden furnitures are consistently mentioned as coming from Meluhha in Sumerian accounts.

(42) Sans. meși मेषी the tree Dalbergia Ougeinensis (Oujeinensis/Ujjeinensis) a.k.a. the Ujjain Desmodium or Desmodium Oojeinense or Ougeinia Oojeinense or in Hindi sandan (from Sans. syandana, see below, not to confuse with candan i.e. Sandal) and many other names

Sum. mes a tree (81x: ED IIIb, Old Akkadian, Ur III, Old Babylonian) wr. ĝešmes Akk. mēsu

It is mentioned to have come from Meluhha in Sumerian records and a popularly cited example. [ĝešmes me-luh]]-ha (Emar 6/1, p. 105-109, Msk 731030 o ii 56; OB Nippur Ura 1 51; IB 1535+ ii 15; Syria 12, pl. 46-47, 03 + pl. 47, 04 o ii 35; SLT 143 o 1; IB 1547 iii 1). states:

"This very pretty and useful tree is a valuable one in India (...) The wood is much in request for agricultural implements, such as ploughs; and, being tough and strong, is useful for carriage-building. It makes excellent furniture. Roxburgh mentions that the pillars of Maharaja Sindhia's palace at Oojein (Ujjain) are made of it". The timber of this species is superior to Teak (Tectona Grandis) in terms of shock resistance, shear strength and hardness (Pearson and Brown 1932). It has a slew of medicinal usages in Ayurveda, Siddha, Folk and Sowa Rigpa systems of medicine. Bark fibers are suitable for making rope. A red, transparent, astringent gum is obtained from incisions in the trunk. It is also a specialty timber for marine plywood. The tree is a host plant for lac producing insects. The resulting shellac is of high quality (Purkayastha and Krishnaswamy 1958).

So named in Sanskrit most probably because of its flowers, which appear similar to face of a sheep i.e. meșa मेष with its ears stretched outwards (c.f. fig. M.1) 


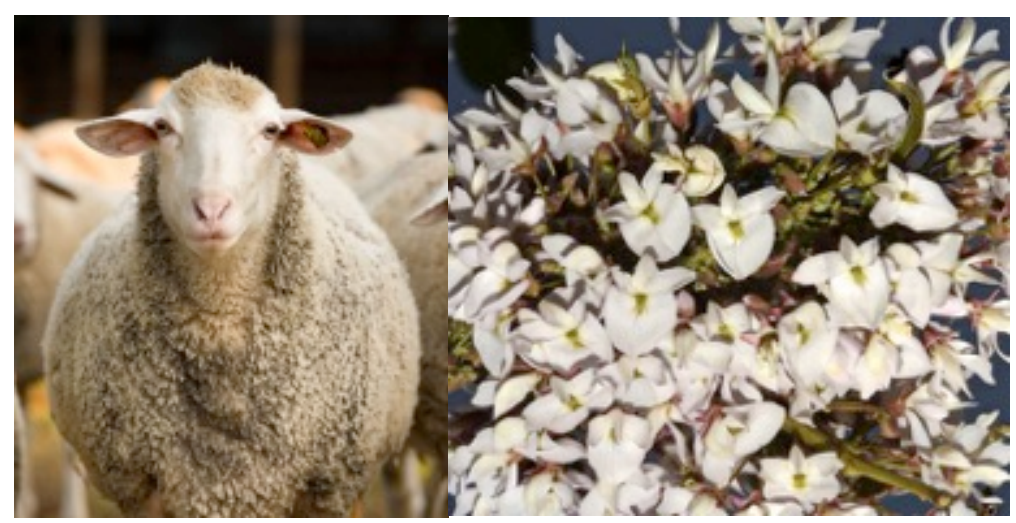

Fig M.1

Dalbergia Ougeinensis is native to Indian subcontinent only. It is found in almost the whole of northern and central India and into the greater part of the Deccan peninsula. Including lower Himalaya from Jammu to Bhutan, Punjab, Sindh (Pakistan), Rajasthan, Gujrat, Maharashtra, Uttar Pradesh, Bihar, Madhya Pradesh, Karnataka and the northern slopes of the Nilgiris.

Its bark is sometimes black, grey or dark brown; hence in Hindi and Marathi, the tree is also known as Kālā Palāsh and Kāla Palas respectively, literally 'a black Butea Monosperma', with which it bears some similarities. Interestingly, in the Mesopotamian text too mes is occasionally referred to as a black tree/wood. Even more interestingly, it is also mentioned as gešmes-babbar, lit. 'a white mes tree'. It could be possibly because of white color of its flowers in central Indian variety as found in Gujarat, Maharashtra and Madhya Pradesh and surrounding regions as opposed to a darker purple hue as found in northern regions like Panjab, Himachal Pradesh, etc. (fig. M.3). In full bloom, the tree of the central Indian variety would actually appear white (fig. M.4). 

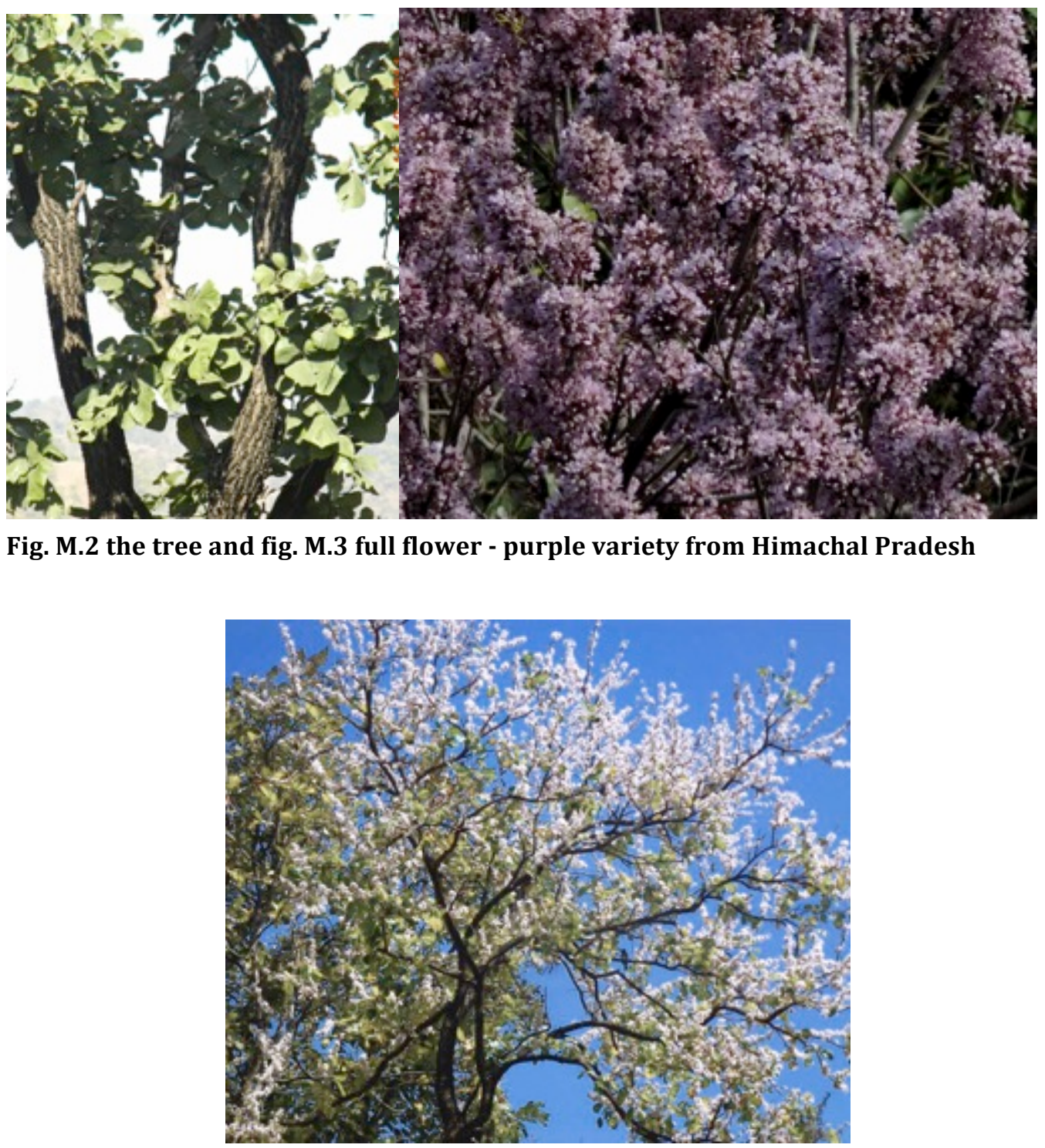

It is mentioned in Rigveda as spandan (iii, 53, 19) in contexts of parts of a chariot. According to V. S. Agrawala (1952) "it certainly denotes a tree. Its variant is syandana. The botanical name may be Ougeinia dalbergioides denoting the tree called sandan in Hindi". Its popularity and usage since ancient periods is reflected in its many Sanskrit names (more than 25!) as 


\begin{tabular}{|c|c|}
\hline Other Sanskrit names of meși & Derived from \\
\hline syandana/syandanadruma/syandani & $\begin{array}{l}\text { syandana - a war-chariot, chariot, } \\
\text { car }\end{array}$ \\
\hline akșaka/akșika/akșìka & $\begin{array}{l}\text { akșa - an axle, axis, wheel, cart, } \\
\text { car, beam, chariot }\end{array}$ \\
\hline cakrin & cakra - wheel \\
\hline nemi/nemin & $\begin{array}{l}\text { nemi - the felly of a wheel, any } \\
\text { circumference or edge or rim }\end{array}$ \\
\hline ratha/rathadru/rathadruma/rathika & $\begin{array}{l}\text { ratha - a chariot, car, especially a } \\
\text { two-wheeled war-chariot, any } \\
\text { vehicle or equipage or carriage } \\
\text { (applied also to the vehicles of the } \\
\text { gods), waggon, cart }\end{array}$ \\
\hline śakața & $\begin{array}{l}\text { śakața - a cart, waggon, car, } \\
\text { carriage, an implement for } \\
\text { preparing grain }\end{array}$ \\
\hline citrakarman & $\begin{array}{l}\text { citrakarman - any extraordinary } \\
\text { act, wonderful deed, a painting, } \\
\text { picture, devoted to various } \\
\text { occupations }\end{array}$ \\
\hline citrakrt & citrakrt - astonishing, painting \\
\hline sarvasādhaka & sarvasādhaka is a name of śiva \\
\hline
\end{tabular}

Consequently, it is called "Chariot tree" in English.

"The natural reproduction of Sandan is excellent, and it is very easily propagated artificially. (...) It is often grown for ornament in gardens and when in full flower and covered with its purple inflorescences, it is very pretty" (Gamble 1881). Intriguingly, as stated earlier, Harappans are also mentioned as keepers and financers of sacred gardens and one of the terms for 'gardener' in Sumerian and Akkadian is Sum. santanak/šandana and Akk. sandanaku. Its leaves are trifoliate. It is worth noting that trefoil designs are present in Harappan art and script (sign no. 233 to 235 Mahadevan 1977). Similar designs are also found in Mesopotamia and considered to be a Harappan influence (Bisht and others). 


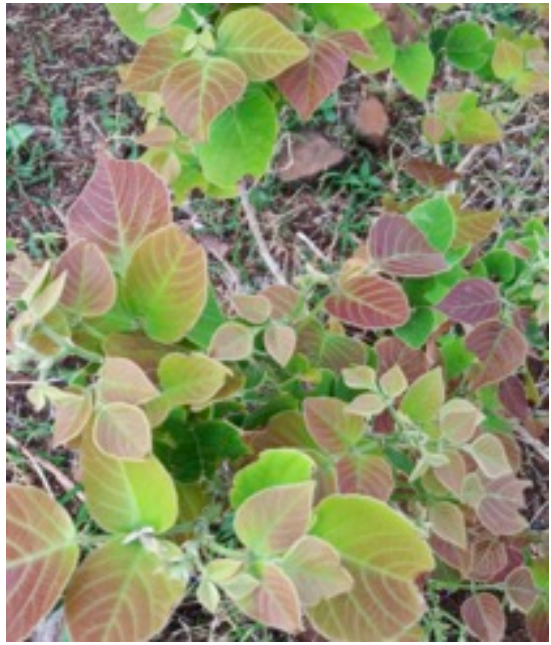

Fig M.5 Trifoliate leaves as seen on a young shrub

No wonder if Harappans used and brought this multi-purpose tree with them to the west. Unfortunately, today, timber exploitation has degraded the natural stands of this species. In fact, according to Jagdish Chander, Chief Conservator of Forests, Haryana state (india), "(in Hariyana) tree has almost become endangered and so is not exploited commercially".

Oddly, despite having much importance historically as suggested by its Sanskrit names, this tree seems to have eluded scholarly attention until now in the studies related to these subjects.

(43) Sans. śimśapā शिंशपा/śāmśapa शांशप the tree Dalbergia Sissoo/made of its wood; commonly known as (North) Indian Rosewood and śiśam, sisam, sissu, etc.

Sum. samazum a tree (1x: Old Babylonian) wr. ĝešsa-ma-zum

It's an important commercial timber species native to Indian subcontinent and southern Iran. It is interesting to compare its popular Indian vernacular forms śiśsm/sisam with Sumerian word.

Gamble (1972/1881) states "the wood is very durable, seasons well, and does not warp or split. It is highly esteemed for all purposes where strength and elasticity are required. (...) It is extensively used for boat-building, carts and carriages, agricultural implements, in construction, and especially for furniture. As a furniture-wood and for carving, it is probably the finest wood in India, and it is in regular demand for these purposes all over the 
North. (...) Sissoo wood is an excellent fuel, good pieces burning almost like coal; it also makes excellent charcoal."

Importantly, it is highly regarded in manufacture of musical instruments for its superior acoustic qualities and durability, traditionally in India - for folk and classical instruments, as well as all over the world today. In fact, it is one of the most widely used woods in guitars (Paiva and Santos, 2014) and in other instruments.

(44) Sans. asana असन the tree Terminalia Tomentosa (synonyms: Terminalia Alata, Terminalia Elliptica) commonly known as Indian Laurel, asain, asin, sain, ain, saaj, aisan, etc.

Another tree that is known with same/similar names vernacularly (śíśam/sisam/sissu, some times with prefix kālā i.e. 'black') and in Sanskrit (krșna-śimśapā, śyāma-śiṃśapā, lit. 'black Dalbergia Sissoo') is Dalbergia Latifolia, also known as (East) Indian Rosewood, Bomabay Blackwood, etc. Found mostly in central and southern parts of India and scarcely in the North. Its wood is similar to D. Sissoo but with a darker purpal shade instead of light brown; highly valuable for furniture work and used for musical instruments as well.

Sum. esi a tree (40x: Ur III) wr. ĝešesi Akk. ušû

A large deciduous tree. It is mentioned to have come from Meluhha in Sumerian records. According to Gamble "perhaps the most widely distributed of all the important Indian forest trees, and the one in the most universal employ for building native houses and other country purposes. It is found in the sub-Himalayan tract and Lower Himalaya from the Ravi eastwards, ascending to $4000 \mathrm{ft}$. in the hills, in places. From the Himalaya it extends down both Peninsulas." The wood is used for furniture, cabinetwork, joinery, paneling, specialty items, boat-building, railroad cross-ties (treated), decorative veneers and for musical instrument. Silkworms (Antheraea paphia) feed on its leaves that produce the Tussar silk, which is a commercially important wild silk. Bark and fruits are used to dye and tan leather. The "white wax" insect (Ceroplastes ceriferus, Sign.) is often found on it, the resulting wax (commonly known as Chinese wax) is used in the manufacture of polishes, sizes, and candles. (Size - a gelatinous 
solution used in glazing paper, stiffening textiles, and preparing plastered walls for decoration)

Asansol city in present day West Bengal state in India is named after this tree. It is situated on the banks of river Damodar where asan trees are also found (possibly from Sans. asana + cola/kula i.e. bank/shore/coast). It is the second largest city in the state and has a long history.

(45) Sans. abja अन्ज the tree Barringtonia Acutangula

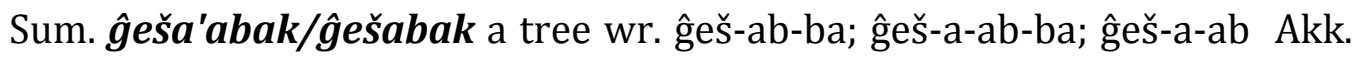

(46) Sans. kūrca कूर्च a bunch of anything, bundle of grass, etc. often used as a seat (Taittirīya Saṃhitā, Śatapatha Brāhmṇa); almost all later Indian (and surrounding region's) languages have words like khurcī, kursi, khuraśī, 
kurcī, kasēra, etc. for chair; also Sans. garta गर्तa high seat, throne (of mitraand varuna-)

Sum. guza chair, stool, throne (1431x: Old Akkadian, Lagash II, Ur III, Early Old Babylonian, Old Babylonian, unknown) wr. ĝešgu-za; gu-za; guz-za; ĝešguza; ĝešaš-te Akk. kussû

It is mentioned to have come from Meluhha in Sumerian records [ᄁešgu-za me-luh-ha (OB Nippur Ura 1 180)]. k>g is common. '-rca' is a non compatible. Akkadian form, kussû, makes it even clearer. The Sanskrit word kürca has most archaic and broad meaning for anything used as a seat. The word seems to have spread in far and wide places and popularly used for chair till today, e.g. Marathi khurcī, Hindi kursi, Gujarati khuraśí, Tulugu kurcī, Malayalam kasēra, Indonesian kursi, Khmer kawei, Arabic kursii, Chinese Y̌̃zi, Thai kêāxī, Malay kerusi, Ukrainian krislo, etc.

(47) Sans. vamśaja वंशज made of or produced from bamboo; from Sans. vamía वंश Bamboo cane (Rigveda), in Hindi, Panjabi, Ranjasthani, Nepali - bānsa, Gujrati - vānsa, Marathi - bāmbū, Bangla - bāṃśa; c.f. Sans. vaṃśa/vaṃśī or

Word 'kursi' and its variations are usually thought to have come from Arabic kursii but the akkadian and sumerian records evidently show its existence well before that and its relation with Meluhha. commonly bānsurī/bansurī/bansarī, flute made of bamboo.

Sum. banšur table (256x: ED IIIa, ED IIIb, Old Akkadian, Ur III, Early Old Babylonian, Old Babylonian) wr. banšur; gešbanšur; banšur, ĝešbanšur 2 ; banšur 3 ; ĝešbanšur, banšur $_{x}(|U R U \times I G I|)$ "table" Akk. paššūru

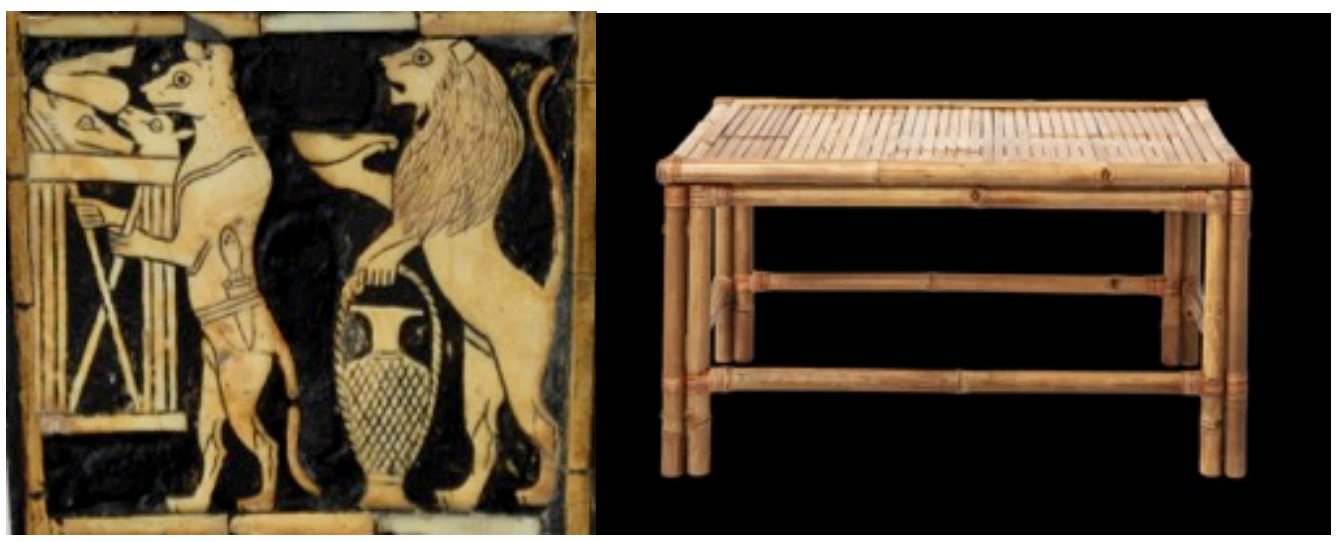

Fig. B.1 serving table seen on panel of a lyre from Ur and fig. B.2 a modern table made from Bamboo 
banšur is mentioned to have come from Meluhha. In Sumerian textual records, it is mostly mentioned with food object including various fishes, pig, sheep, cheese, bread, fruits, etc. In Mesopotamian iconography, tables with food and drinks are shown in many banquet scenes as found on seals and otherwise. Those tables appear very similar to furniture made from Bamboo (c.f. fig. B.1 and B.2). Figure B1 shows the second register of the panel on one of the bull-headed lyre from Ur cemetery (discussed in later in this text), an animal costumed figure is carrying a similar table, lifting it quite high. Bamboo furniture can be far lighter in weight than the ones made from any hardwood and thus, serving in the manner shown on lyre is actually very much possible. Bamboos are of notable economic and cultural significance in South Asia, Southeast Asia and East Asia where majority of the Bamboo species are found and being used for building materials, furniture, as a food source, as a versatile raw product and for musical instruments since ancient periods. Its uses are mentioned in Rigveda.

(48) Sans. mattavāraṇa मत्तवारण a bedstead Sum. mayaltum bed (44x: Ur III, Early Old Babylonian, Old Babylonian) wr. gešma-al-tum; ĝešma-a-al-tum Akk. Mayyaltum

(49) Sans. mañca मश्च a bedstead, couch Sum. maršum bed (2x: Old Babylonian) wr. ĝešmar-šum Akk. maršu;

(50) Sans. mañginī मड़िनी a boat, ship Sum. magilum a boat (5x: Old Babylonian) wr. ĝešma2-gi 4 -lum; ĝešma2-gilum; ĝešma2-gi-la 2 Akk. magillu

Identified as coming from Meluhha in Sumerian records - ğišma -gi $_{4}$-lum me-luh-ha-ki-a-ke 4 (Enki and the world order 128) 
1359

1360

1361

1362

1363

1364

1365

1366

1367

1368

1369

1370

1371

1372

1373

1374

1375

1376

1377

1378

1379

1380

1381

1382

1383

1384

1385

1386

1387

1388

1389

1390

1391

1392

1393

1394

1395

(51) Sans. gopura गोपुर the ornamented gateway of a temple Sum. ĝ $\mathbf{e s ̌ b u r}$ architectural ornament (5x: Old Babylonian) wr. ĝeš-bur2

' $\mathrm{o}$ ' is non compatible, $\mathrm{p}>\mathrm{b}$ is commonly seen here. Sumerian texts clearly suggest it to be a door ornament or gateway or gate (most likely wooden as suggested by use of $\hat{g} e s ̌$ in place of 'go-'). E.g.:

gišs-bur 2 -ba me-te $\mathrm{e}_{2}$-a-ke ${ }_{4} \mathrm{ni}_{2} \mathrm{il}_{2}-\mathrm{il}_{2}$-a il $\mathrm{il}_{2}$-bi ba-e-gub (The lament for Eridug 44)

The loftiness of its awe-inspiring door-ornament, befitting a house, collapsed. (ETCSL)

e $_{2}$-e ĝ giš-bur 2 mah-bi ba-šub bad 3 -si-bi ba-gul (The lament for Sumer and Urim 420)

The house's great door ornament fell down, its parapet was destroyed. (ETCSL)

giš-bur 2 -de muš-šag $_{4}$-tur 3 muš-huš-e gu gu $_{2}$-da $a_{3}$-mi-ib-la 2 (The temple hymns 418)

(...) on your awesome and radiant gate a horned viper and a mušhuš are being seized in a trap. OR (...) on your awesome and radiant gate a decoration displays horned viper and a mušhuš embracing.

(52) Sans. sūtrakāra सूत्रकार a carpenter (Rāmāyaṇa)

Sum. šukara carpenter wr. ${ }_{2}{ }_{2}$ gě̌šu-kara 2 ; ĝě̌šu-kara 2 Akk. naggāru

(53) Sans. ammarä अम्मरा the second beam of timber over a door

Sum. amra/amru beam, timber (15x: ED IIIb, Ur III) wr. am-ra; am-ru; amra Akk. amrû

(54) Sans. praśas प्रश्र a hatchet, axe, knife (Aitareya Brahmana) also paraśu परशु

Sum. pašu a type of axe (1x: Old Babylonian) wr. pa-a-šu

There are other words for axe in Sumerian that are older and more popular; least popular is pašu with only single entry. 


\section{Jewellery}

(55) Sans. sindhu सिन्धु the Indus river

Sum. hindum a bead (3x: Ur III) wr. hi-in-dum

Harappan beads are found almost all over Mesopotamia and are one of the

(56) Sans. hära हार a garland of pearls, necklace (according to some, one of 108 Hindum seems to be the only word in Sumerian dictionary (PSD) that starts with 'hin' (or hi-in) combination. Many other words exist for bead in Sumerian, e.g. ellaĝ, nunuz, ad, allanum, za, etc. most important Harappan export attested in archaeology. As mentioned earlier, historically, variations of the word sindhu have been used to identify the region i.e. Indian subcontinent - the area around and beyond sindhu river, its people, culture, ethnicity, religion and products. E.g. later Akkadian words attested in Standard Babylonian, sindu/sinda/sindū and sinduja (c.f Sans. sindhuja, born or produced in the country Sindh, Mahābhārata), used as adjective 'Indian' (said for Indian wood). The ancient Greeks referred to the Indians as Indoi ('Iv $\delta o i$ ), "the people of the Indus" and Persian used hindu for the same.

(57) Sans. hiranya हिरण्य any vessel or ornament made of gold RV AV

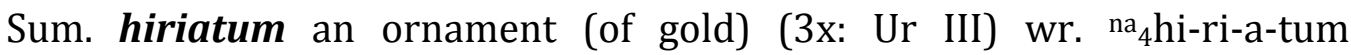
Akk. hirītu

Always mentioned/associated with gold in Sumerian. Again noncompatible ending i.e. -anya becomes '-tum'.

(58) Sans. karnāndu कर्णान्दु an ear-ring Sum. kamkammatum earring (30x: Ur III, Old Babylonian) wr. kam-kamma-tum Akk. anşabtu 
1432

1433

1434

1435

1436

1437

1438

1439

1440

1441

1442

1443

1444

1445

1446

1447

1448

1449

1450

1451

1452

1453

1454

1455

1456

1457

1458

1459

1460

1461

1462

1463

1464

1465

1466

1467

1468

(59) Sans. śaranda शरण्ड a kind of ornament

Sum. šerkan ornament (56x: Ur III, Old Babylonian) wr. še-er-ha-an; še-erka-an; še-er-kan2; še-er-ga-an; še-er-kan

(60) Sans. nepathya नेपथ्य an ornament, decoration, costume (especially of an actor), attire, Mahābhārata, etc.

Sum. nabihum an ornament (65x: Ur III) wr. na-bi2-hu-um Akk. nabihu

$\mathrm{p}>\mathrm{b}$ is commonly seen here. -thya is non-compatible ending (tum/lum/hum pattern)

\section{Trade - General Terms}

(61) Sans. mudra seal, inscription, mark, gesture, pose

Sum. musara inscription (55x: ED IIIb, Old Akkadian, Lagash II, Ur III, Old Babylonian) wr. mu-sar-ra Akk. Musarû

Sum. mašdara inscription (3x: Ur III, Old Babylonian) wr. ĝešmaš-dara3 Akk. mašţaru

Seals most likely played a very important role in Harappan trading methods. As mentioned earlier, many Harappan and "Indus style" seals are found in Mesopotamia.

In Sanskrit, word mudra has wide spread, varied and important usage in the context of fields like yoga, art, music, dance, drama, martial arts; many types of symbolic or ritual gestures or poses in Hinduism, Jainism and Buddhism; economy (in this context, it means money in general and coin as well); trade and administration (i.e. seal or mark); jewellery (finger ring); and even for sexual positions! This gives an impression that origin of this word could be very ancient. In Rigveda, it appears as part of a name Lopamudra, which may show popularity of the word in common people.

(62) Sans. sravadrangga सवद्रड़न market, bazaar, stirring town, a fair Sum. šakanka market; market-price (10x: Old Babylonian) wr. šakanka Akk. mahīru 
1469

1470

1471

1472

1473

1474

1475

1476

1477

1478

1479

1480

1481

1482

1483

1484

1485

1486

1487

1488

1489

1490

1491

1492

1493

1494

1495

1496

1497

1498

1499

1500

1501

1502

1503

(63) Sans. nidhimat निधिमत् containing treasure or forming a store, abundant (Rigveda)

Sum. nakamtum storehouse (9x: Early Old Babylonian, Old Babylonian) wr. na-kam-tum

(64) Sans. goran்ku गोरङुु a bailsman, guarantee Sum. ginatum guarantee (10x: Ur III) wr. gi-na-tum "' Akk. tūnātu "o" is non compatible, there is no word in Sumerian (PSD) that has ranku or anku anywhere in the word. We have seen this particular pattern of use of 'tum' etc. as a replacement for such non-compatible parts at the end of the word.

(65) Sans. śratkr श्रत्कृ to make secure, guarantee (Rigveda)

Sum. šudua guarantee (31x: ED IIIb, Old Akkadian, Ur III, Old Babylonian) wr. šu-dus-a

Except for ś, everything else seems non-compatible.

(66) Sans. sarga सर्ग agreement, assent

Sum. šega agreement (16x: Early Old Babylonian, Old Babylonian, unknown) wr. še-ga Akk. mitgurtu

\section{Trade - Miscellaneous}

(67) Sans. krvi कृवि Name of a utensil used by a weaver, loom (?) (Uṇādi-sūtra iv, 57)

Sum. kura loom; a designation of looms (1x: Old Babylonian) wr. ŝeškurra; ŝeškur 4 -ra; ĝ̀ešku-ra Akk. işi kura

(68) Sans. akșadevana अक्षदेवन dice-playing, gambling

Sum. EKIDma a wooden object used in a game (9x: Old Babylonian) wr. ĝešE.KID-ma 
Harappan dices are found at many places in Mesopotamia (Dales 1979).

(69) Sans. ürṇā ऊर्णा wool, a woollen thread, thread (Rigveda, etc.) Sum. ulin twine, colored twine wr. $\mathrm{u}_{2}$-li-in Akk. barumtu

(70) Sans. kșurin क्षुरिन् a barber Sum. šu'i barber wr. šu-i Akk. gallabu

\section{Animals}

As cited earlier, Meluhhan ships exported many animals to Mesopotamia. Here are some of the Sumerian terms that are found similar to Sanskrit in this context.

(71) Sans. amsakūta अंसकूट a bull's hump, the protuberance between an ox's 1519 shoulders.

(72) Sans. nandi śiva's bull; also nanda son, RV

Humped bull is native to south Asia and considered to have reached Mesopotamia with Harappans.

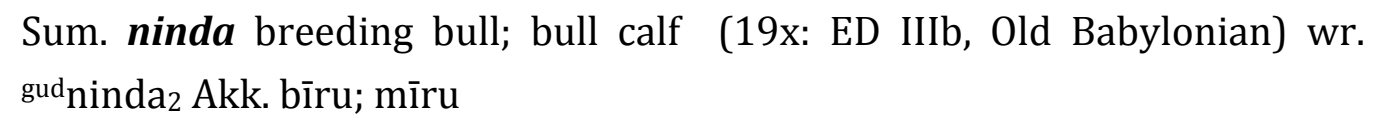
Sum. ninda breeding bull; bull calf (19x: ED IIIb, Old Babylonian) wr. gudninda 2 Akk. bīru; mīru

$$
\begin{aligned}
& \text { It is important to note that siva's bull too is a calf and not a fully-grown bull. } \\
& \text { It is a very commonly seen human behavior to address (and actually } \\
& \text { consider) pets as sons and daughters. It is possible that early people } \\
& \text { addressed their bull calves as nanda, their son or its affectionate variations } \\
& \text { like nandi or nandu, still used in names of people. }
\end{aligned}
$$

(73) Sans. romaś/lomaś a goat (Rigveda)

Sum. maš goat; extispicy; sacrificial animal for omens (10699x: ED IIIa, ED IIIb, Old Akkadian, Lagash II, Ur III, Early Old Babylonian, Old Babylonian, 1st millennium) wr. maš2; maš Akk. bīru; urīşu

Intial clipping like in kinnara (both words are discussed with word no. 29 
kinnara above). On translator's seal (above) we see a figure holding a (baby) goat.

(74) Sans. barkara बर्कर a goat

Sum. barakara (meaning unknown) (3x: Ur III) wr. ba-ra-kar-ra

(75) Sans. huḍu हुडु a ram

(76) Sans. bhaidaka भैडक (fr. bheḍa, bheṇda) relating to or coming from a sheep Sum. udu sheep (28818x: ED IIIa, ED IIIb, Ebla, Old Akkadian, Lagash II, Ur III, Early Old Babylonian, Old Babylonian, 1st millennium, unknown) wr. udu; e-ze 2 Akk. immeru

(77) Sans. vrșākapi वृषाकपि "man-ape" or "great-ape" Rigveda (RV iv, 18, 8) a mythological anthropomorphic monkey like creature; Sans. kapi a monkey Sum. ugubi monkey (13x: Old Babylonian) wr. ugu ggu $_{4}-\mathrm{bi}$; ${ }^{\text {ugu}} \mathrm{u}_{-}-\mathrm{gu}_{5}-\mathrm{bi}$ Akk. uqūpu 'Vrș' is non-compatible and $k>g$ and $p>b$ are common. It is understood that Indian monkeys reached Mesopotamia. Figurines of monkeys performing act of climbing on a stick or in various acrobatic poses are found at Indus sites. Kenoyer suggests that pet monkeys were probably a common sight in the bazaars or neighborhood markets of Indus cities (Kenoyer 1998). Similar figurines are found in Mesopotamia as well and it is generally thought that the bulk of Early Dynastic to Larsa period monkey figurines in Mesopotamia depicts Indian primates (Ratnagar 1984, Possehl 1994). There are still-present traditions of classes of folk/street performers who 
perform with a short tailed monkey. The monkey is mostly dressed like a human. As part of their performance, they address the monkey using mischievous names to generate interest in the audience. They usually emphasize that their monkey is no ordinary one; it has human like or even super-human qualities and more. 'Vrșākapi' surely fits such descriptions and its transformation into ugubi is well within the scope of the formula. Same strategy could have helped merchants who were selling monkey figurines.

(78) Sans. vājibhūmi वाजिभूमि a place where horses are bred or a spot abounding in or suitable for horses.

Sum. wadaltum shed? a shed where animals are born? (3x: Ur III) wr. wada-al-tum Akk. ?

It is very rare in Sumerian for words to start with ' $w$ '.

(79) Sans. hamsira हंसिर a kind of mouse

Sum. humsirum mouse wr. ha-mun-zi-lum Akk. humşīru

Possibly a large mouse (a rat?) according to Akkadian records. Stories about ship-rats are present everywhere in world. This could be a species that travelled on ships and reached.

\section{Other Words}

Most of the words listed above are related to the fields that can be connected with Harappans or south Asia through some way or the other. But given the influence seen in above list, there could be many more words related to general human activities. Only some examples are presented here:

\section{Disease}

Humans do fall ill and so would Harappans in Mesopotamia. It appears that some of Indian names of disease also got attested. Here are some as under: 
1614 (80) Sans. adhimāmsaka अधिमांसक impaction; inflammatory oedema of the last 1615 molar teeth or wisdom teeth; proud flesh or cancer (especially in the eyes 1616 or the back part of the gums) Sum. amudaseke dropsy (1x: Old Babylonian) wr. a-mud-a-se ${ }_{3}$-ke

(81) Sans. angaja अड्गज a disease

Sum. aganĝar a disease (1x: Old Babylonian) wr. a-ga-an-ĝar

(82) Sans. ajagallikā अजगल्लिका "goat's cheek"; an infantile disease Sum. ấgizzal a disease (1x: Old Babylonian) wr. aĝizzal ${ }_{x}$ 1625

(83) Sans. agnidāha अग्निदाह a particular disease Sum. agantum skin disease (5x: Old Babylonian) wr. a-ga-an-tum 3 Akk. epqēnu

\section{Other - Miscellaneous}

(84) Sans. sneha स्नेह tenderness, love, blandness, attachment to, fondness or affection for Sum. neha calm, peace (14x: Old Babylonian) wr. ne-ha Akk. nēhtu

(85) Sans. mud joy, happiness, gladness, etc. (Rigveda, Vajasneyi Samhita) Sum. mud joy (1x: Old Babylonian) wr. mud 5 Mud has many meanings in Sumerian. Most attested is 'jar'. Others are tube, 1646

(86) Sans. umā उमा fame, reputation, splendour, light, wife of the god śiva; also called pārvatī and durgā 
Sum. uma triumph, victory (18x: Ur III, Old Babylonian) wr. u3-ma; u2-ma Akk. ernittu

(87) Sans. mah मह / maha मह great, strong, powerful, mighty, abundant (Rigveda, Vajasneyi Samhita)

Sum. mah great; (to be) great (3271x: ED IIIb, Old Akkadian, Lagash II, Ur III, Early Old Babylonian, Old Babylonian, unknown) wr. mah; mah Akk. kabtu; mādu; rabû; şīru

Sanskrit and later indo Aryan speakers have a habit of using "maha" (as an adjective) with almost everything to show a greatness or superlative quality, e.g. pandit-maha pandit, gyani-maha gyani and many more. Similar practice is found to be present in many Sumerian examples where the word is used for same purpose. But as suffix instead of prefix. E.g. gala 'lament singer' - galamah 'chief lament singer'; agrig 'steward, housekeeper' agrigmah 'top administrator'.

(88) Sans. amlavetasa अम्लवेतस vinegar (obtained from fruit) Sum. âgeštinak vinegar (98x: ED IIIb, Old Akkadian, Ur III, Old Babylonian) wr. a-ĝeštin-na

Almost entire word seems non-compatible as 'am-la' combination in the beginning of the word is not seen as well as ' $v$ ', and even $t$-s- (with any vowel) in the end too is quite rare.

(89) Sans. śanda शण्ड name of an asura priest (son of śukra); name of a demon, a patronym (Vajasneyi Samhita, Maitrayani Samhita)

Sum. saĝga an official, the chief administrator of a temple household (1862x: ED IIIa, ED IIIb, Old Akkadian, Lagash II, Ur III, Old Babylonian) wr. saĝĝa; |GAR.ŠID|; |ŠID.GAR| Akk. šangû

ṇda is non-compatible (see bhaṇḍa above).

(90) Sans. saranyu/śaranyu सरण्यु/शरण्यु wind, air

Sum. satium east wind; east; easterner (7x: Ur III, Old Babylonian)

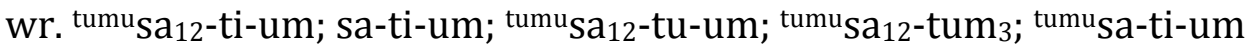


-ranyu is non-compatible. It is very interesting to compare the meaning in both the languages. Indus Valley is, in fact, in the east of Mesopotamia.

Much more study from all angles is required to understand this phenomenon and its extent. Its implications can be far reaching. The sumerianization process requires investigation from sumerologists. Formula is a general indicator of the patterns that were seen in musical terms that lead to the discovery of other words that were following similar patterns, which also confirmed the music related data. But the apparent accuracy in transformation of many of the words may suggest the possibility of some kind of active human involvement in the process. It is possible that interpreters like Shu-ilishu were probably not only translating the languages but also employing mechanisms similar to Phono-Semantic Matching to bring foreign words into local languages. It is also possible that early Harappan traders or their scribes themselves may have started sumerianizing their words for local customers and also, importantly, to make them expressible in the cuneiform script.

About $30 \%$ of the words are attested since Early Dynastic periods but they are also some of the important ones, e.g. classes of musicians and jesters i.e. kinnara, gatr/gala, bhāṇda, vidūṣaka; most of the measuring units; some of the trees/timbre and furniture and some other trade related terms including seal; etc. This suggests that Harappan cultural and commercial influence was already established by this time, which confirms with conclusions drawn by During Casper (see above) and many others.

It seems likely that early Harappan merchants had a practice of keeping musicians with them. As the data suggest, Harappan music and performances 
So does this data provide definitive evidence for the language of Indus Valley?

This is a big question and requires debate but here are a few observations:

(a) Data is statistically significant and found en-bulk in the areas where Harappan words were likely to be found. Their periods of attestation, i.e. from Early Dynastic, through Akkadian till Old Babylonian, correspond with

(b) Majority of the words found in this study, are technical terms i.e. 'jargon', e.g. musical terms, measuring units and other trade related terms. Jargon is the specialized terminology associated with a particular field or area of activity (Murray, 2012). Most jargon is technical terms, involving terms of art, or industry terms, with particular meaning within a specific industry. Use of jargon can make it very difficult for the outsiders to understand a conversation between members of a given group, even if they speak same language. There can be very rare, random or coincidental similarities but it is not likely for technical terms to be very similar en-bulk in unrelated languages without borrowing. For example, without some kind of direct influence, it would be highly unlikely that about $50 \%$ of the musical terms in Sumerian dictionary would be very similar in sound and meaning to those found in a linguistically and geographically unrelated language i.e. Sanskrit. This is way beyond some random coincidence; direct contact would be very crucial to account for such an occurrence. Musical instruments themselves are inventions and similarity in instruments and their names between different areas are usually considered as a sign of borrowing.

(c) For these words to have come from Mesopotamia to south Asia, there should be at least some archaeological evidence found in Harappan sites accounting for such degree of Mesopotamian influence. However, as mentioned above, there are none - not even a single object of clear Mesopotamian origin is identified till now in the Indus realm (Parpola, Vidale, etc., see above). Whereas, as detailed earlier, a lot of Harappan activity is recorded in Mesopotamia. There is also a well-defined presence of symbols of Harappan 
origin or resemblance in Mesopotamian art, (a part of that is discussed in the section of archaeological evidence below).

(d) Just like nature of relation between Indus Valley and Mesopotamia, the formula too appears to be 'one-way ticket', because it provides a way for Sanskrit to Sumerian but the other way round doesn't seem possible. In other words, for many cases it is not possible to obtain Sanskrit words from

(e) Most significantly, several words are related to items that are native to south Asia or known to have reached Mesopotamia through Harappans. E.g. humped bull, species of trees/wood, units of measurement, seals, beads, dice, wooden furniture, monkey, etc. E.g. Humped bull (zebu) is one of the important and clinching evidence, which is native to south Asia (and not to west or central Asia) and established to have reached west Asia with Harappans. Sumerian word is found to be similar to Sanskrit for bull's hump (word no. 71). It is also depicted clearly on a tablet with a drawing of a musical instrument along with the name of the instrument (fig. 5), which too, has a corresponding Indian term (word no. 25). Similar is the case of species of trees, which are stated in relation with Meluhha in Sumerian records and are native to south Asia (and foreign to either of west or central Asia). Importantly, both the major categories i.e. music and trade have words that corresponds to sans. Sindhu (Indus) for different purposes. Which is how the world has identified the south Asian region, people, their religion and products throughout historic period and till today - India.

(f) Some words are specific to India from Indo-European (IE) perspective as well i.e. corresponding terms are not present in other IE languages e.g. vāṇa, gargar, akśa, koś, goṇī, śaṇda, bhāṇ̣a, etc. (Kuiper 1955, 1991). Again, some of these too are related to known Harappan exports to Mesopotamia. An example could be akśa-devana, game of dice, present in Harappan archaeology, known to have reached Mesopotamia with Harappans (Dales 
1979) and the Sanskrit word for dice 'akśa' is not related to other IndoEuropean languages.

(g) Words are Indo Aryan (Sanskrit) in nature. Which is the language of the earliest known texts from south Asia that pertain to the same geographic areas as that of Indus civilization. Rigveda is generally dated around 15001200 BCE and a wider approximation is also given i.e. 1700-1100 BCE. These dates overlap with late Harappan period (ending around 1300 BCE). Although suggestions of its early dates (sometimes based on astronomy) may go to $3^{\text {rd }}$ or $4^{\text {th }}$ millennia BCE or even earlier. Later parts of these dateranges are mostly related to completion of the text. This is because of the fact that Rigveda is not a single book but a multilayered compilation. The Rigveda Samhita is the core text (considered to be the oldest), which itself is a collection of 10 books (mandala-s) with about 10,552 verses in 1,028 hymns (sūkta-s) composed by many families of sages and others over an unknown period of time.

The archaeological evidence and the circumstances present with the data seems to unambiguously connect it to Harappans and at the same time contradict with other possibilities i.e. origin of this phenomenon in either Mesopotamia or Central Asia.

According to the generally excepted hypothesis, Indo-Aryan language reached south Asia around $1^{\text {st }}$ half or middle of second millennia BCE with pastoralists from central Asia. But this data seem to suggest that there is a strong possibility that Indo Aryan (Sanskrit) was already present in south Asia in Indus Valley civilization. According to this data, Harappans who travelled, traded and settled in Mesopotamia may have spoken a form of Sanskrit or it was the lingua franca of the Indus region. Detailed linguistic study is required to know the exact type of Sanskrit. 


\section{Archaeological Evidence}

1846 Given the kind of cultural impact suggested by Sumerian texts, there should be 1847 some evidence related to music, recorded in archeology of the region as well. A 1848 study of iconography in Mesopotamian archaeological records showed many 1849 compelling parallels in musical traditions between both the cultures. A 1850 forthcoming paper (briefed in the introduction section) talks about music related 1851 evidence found at various Harappan sites that show the possibility of existence 1852 of many instruments. It also provides a comparative study with Mesopotamian 1853 records. Suffice to say here that many of those possible Harappan instruments 1854 have parallels in Mesopotamian art and their Sanskrit names are recorded in 1855 Sumerian texts. This paper, instead, particularly concentrates on certain 1856 identifiable aspects of south Asian musical traditions, which may have reached 1857 and assimilated into Mesopotamian culture and seen in archaeological records 1858 there. Importantly, it predicted the possibility of existence of a Harappan lyre, 1859 shaped realistically like a bull, which may have travelled from the Indus Valley to 1860 Mesopotamia and evolved there in local styles as found in the Royal Cemetery of 1861 Ur. 

instruments (and other objects) and animal-musicians

Zoomorphism is found in many cultures around the world but Indian traditions seem to have taken these ideas to a completely different level. Zoomorphism (applying animal-attributes or designs to humans and objects), anthropomorphism (giving human qualities to animals) and therianthropomorphism (shape shifting beings), in general, are prevalent refrains in Indian cultural spheres since prehistoric periods and can be seen in countless examples. Largest majority of the Indus seals have animals as the principal motif. Further interesting development of the idea is seen on many seals in form of composite animals, where various parts of different animals are mixed. In certain examples, there are multiple heads emanating from a common neck and each head is of a different animal. There are anthropomorphic horned deities in terracotta figurines and on seals. On a famous seal, a human figure (probably a deity, sometimes called paśupati or proto- śiva) with water buffalo horns is flanked with many animals and is sitting in possibly a yogic posture on a throne that also has animals carved on it. On another seal, we find a half-human and half-tiger figure. There are zoomorphic lamps (mostly bull or cow), bird-shaped ocarina type whistles, pottery with zoomorphic figures and miniaturized terracotta anthropomorphic masks excavated at various Indus sites. There is a continuity of similar ideas in material culture till modern times (Fig 6: Seals, Lamps and other objects). Some signs in Indus script too have zoomorphic shapes. Kenoyer (2010) is a very good reference here, a few relevant excerpts:

"Iconographic depictions of humans and animals, as well as interactions between the two, are common in the art and graphic expression of South Asia, beginning as early as the late Upper Palaeolithic (ca.12,000 YA) and Mesolithic periods (10,000 YA) (Kenoyer 1992)". “(...) anthropomorphic figures, have a long history beginning in the Upper Palaeolithic, continuing through the Indus Tradition, up to the present."

"During the Early Harappan phase (ca. 3300-2800 BC) conflict scenes with humans and animals, as well as depictions of horned anthropomorphic images that may have been shamans or deities, are found at many sites throughout the Indus Valley. (...) These early motifs continued to be used in the subsequent 1905 Harappan phase (ca. 2600-1900 BC) when Indus cities established vast economic and ideological networks." 
“ (...) Other images portray animal-headed humans or human-headed animals

1909 that may represent complementary or contrasting imagery of what might be 1910 anthropomorphic animal deities or an Animal Master or Mistress."

Likewise, in earliest records of Hindu religious imagery we see a supernatural anthropomorphic monkey like creature "Vrșākapi" of Rigveda; many of the

1914 important divinities like Indra, in Rigveda, have zoomorphic forms e.g. a vriśabh 1915 or bull, Aśva or horse, Mesha or a ram and so on; later Gods like Ganeśa, Varāha, 1916 Narsimhā and Hanumān etc. have heads of animals like elephant, wild bore, lion 1917 and monkey respectively with human body (sometimes with other animal like 1918 features as well); there are also multi-headed versions of many gods where each 1919 head is of a different animal; as well as other therianthropic figures such as the 1920 Nagas and Garudas etc. A non-religious and very important example is highly 1921 popular anthropomorphic characters of Panchtantra. Early date for its surviving 1922 version is around $300 \mathrm{BCE}$ but it is understood to have content whose roots may 1923 go back to vedic period and even beyond (cit?). This list can go on and on, but for 1924 this study, the most relevant manifestation of these ideas is the tradition of 1925 zoomorphic musical instruments and various classes of zoo/anthropomorphic 1926 musicians such as Kimpurusa-s, Kinnara-s, Gandharva-s and Bhand-s.

It is important to note that what we are discussing here, are general artistic ideas 1929 and aesthetic choices that have been repeatedly seen in the subcontinent and are not specifically related with any language or religion. Rather, it is an overencompassing cultural phenomenon. Irrespective of the interpretations these ideas held in different periods, these particular aesthetic choices show a remarkable continuity from very early periods to modern times and present themselves in large variety. In India, there is a long-drawn tradition of making instruments (specially 1937 chordophones i.e. stringed ones but others too) entirely in the form of various animals and birds and thereby lending their name to the respective instrument, as already mentioned earlier. The tradition of such chordophones continued in 1940 India until recently, although animal motifs and partially zoomorphic designs 1941 still continues. Mahābhärata mentions many instruments that are zoomorphic 1942 such as nandi (a bull shaped instrument), kachchapi (a turtle shaped lute), 1943 gomukha (an instrument with cow or bull's head), govishan (a trumpet made 1944 from cow or bull's horn) and rudri (partially zoomorphic, still continues) etc. 
1945 Lātyāyana (a late vedic period author) mentioned an instrument named 1946 kapiśîrșnī कपिशीष्णी, 'kapi' is monkey and śirșa is head, therefore, it could be an 1947 instrument with monkey's head attached to it or shaped like it in full or part. Fig. 19486 (6.1-6.12) shows a whole gamut of animals shown as instruments from 1949 different areas and originating periods in India, which have continued and 1950 survived (at least in museums). A few examples of other objects are also 1951 included, which show presence of a larger cultural phenomenon.

1953 Fig. 6: (6.1) Peacock harp (6.2) Peacock lute (6.3) Fish Harp (6.4) Fish clapper 1954 (6.5) Fish Object (6.6) Crocodile lute (6.7) Crocodile harp (6.8) Tortoise Lute 1955 (6.9) Tortoise Fiddle (6.10) Anthropomorphic Snake Trumpet (6.11) zoomorphic 1956 objects. Interestingly, all of these animals i.e. fish, peacock, crocodile, tortoise and 1957 even snake etc. are recurring features in Harappan art too.

1958

1959

1960

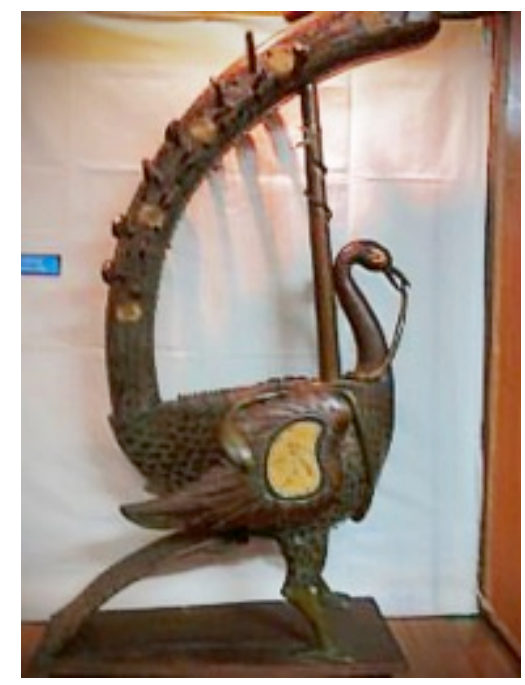




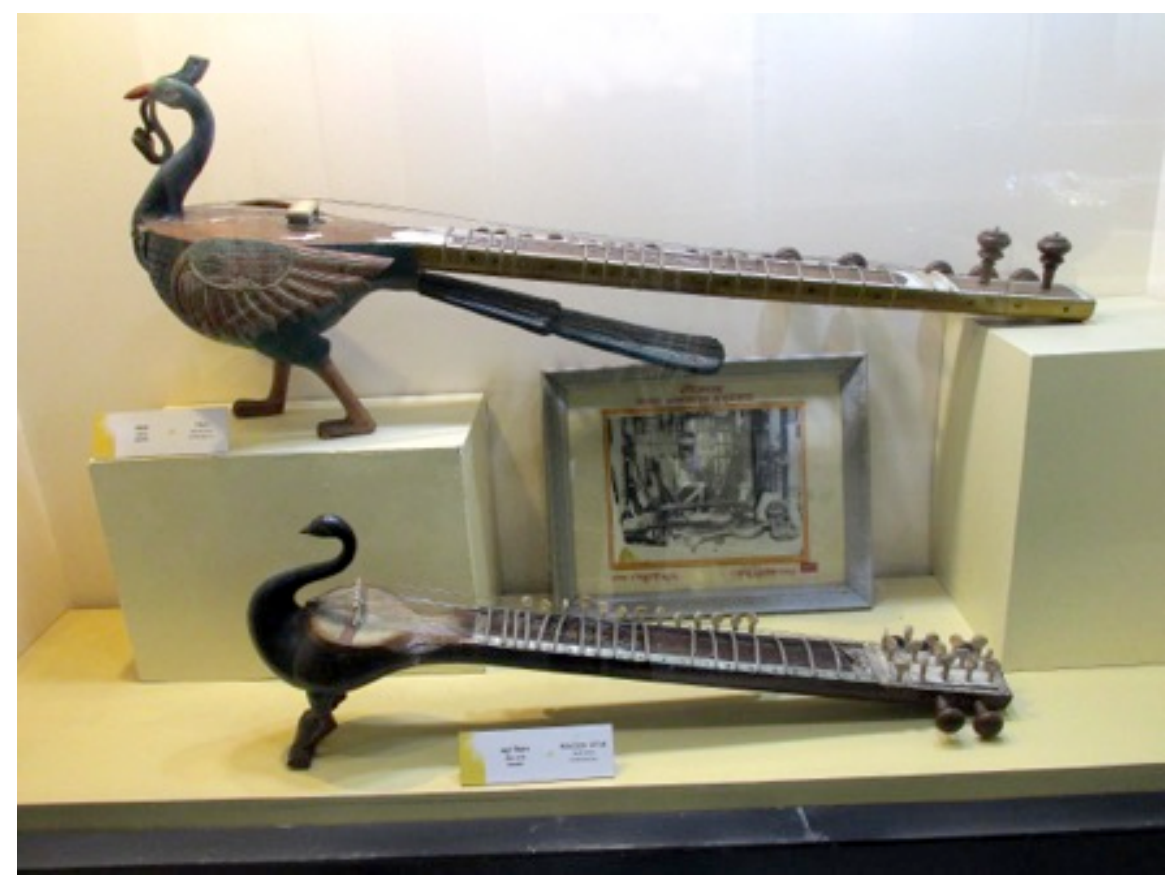

Fig. 6.2: (Above) Peacock Lutes, despite similar shape these are different instruments - one is plucked and other is bowed instrument. (Below) Another exquisite specimen at MET museum
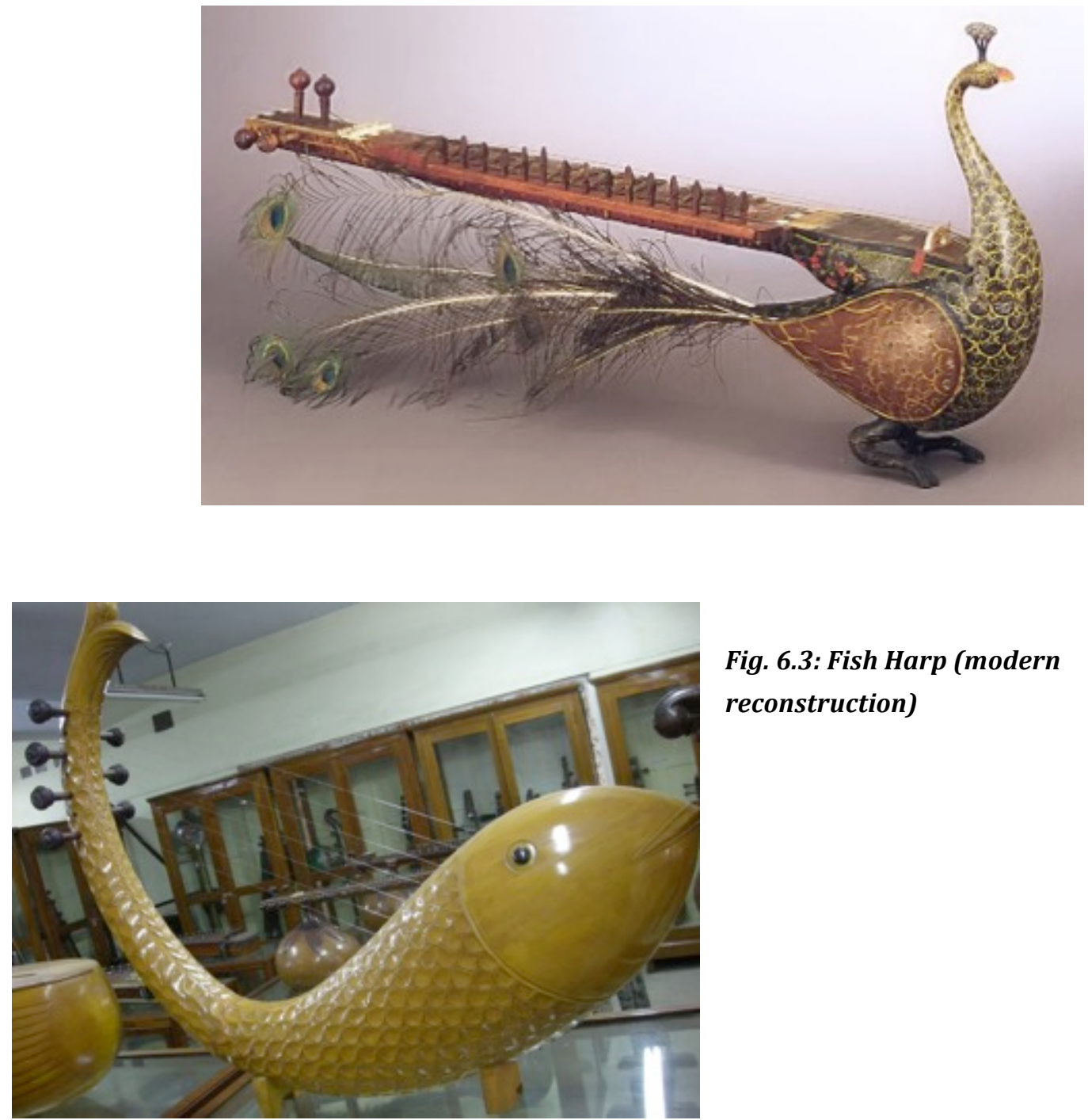

Fig. 6.3: Fish Harp (modern reconstruction) 
1978 1979 1980 1981

1982 1983 1984 1985

1986 1987 1988 1989

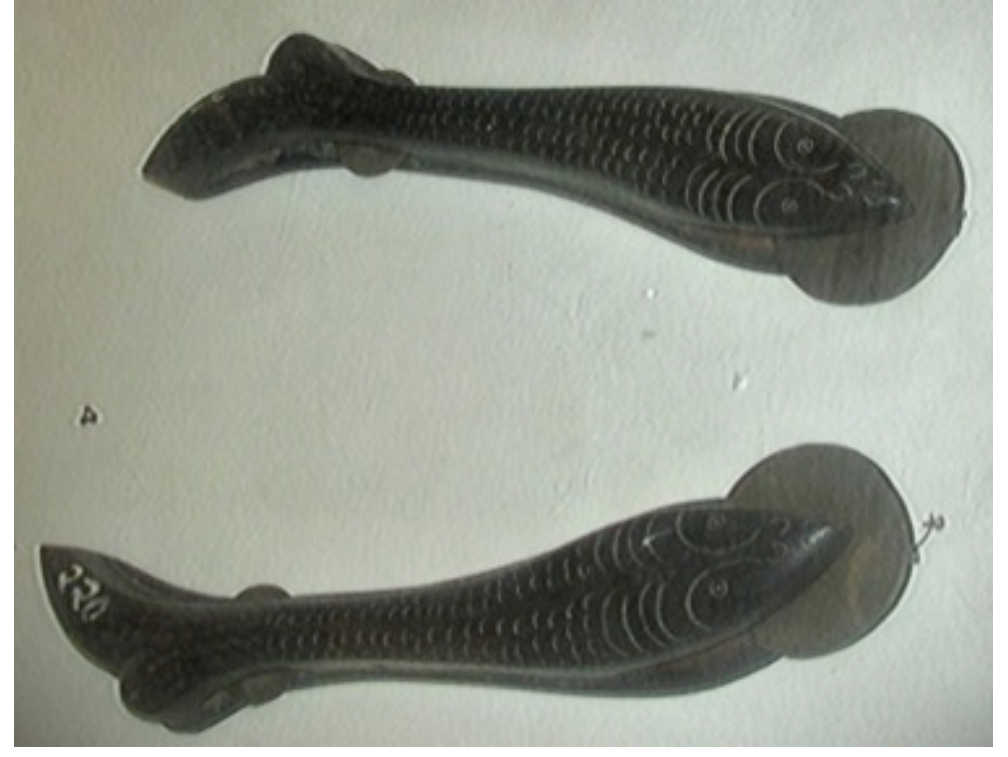

Fig. 6.4: Fish Clappers

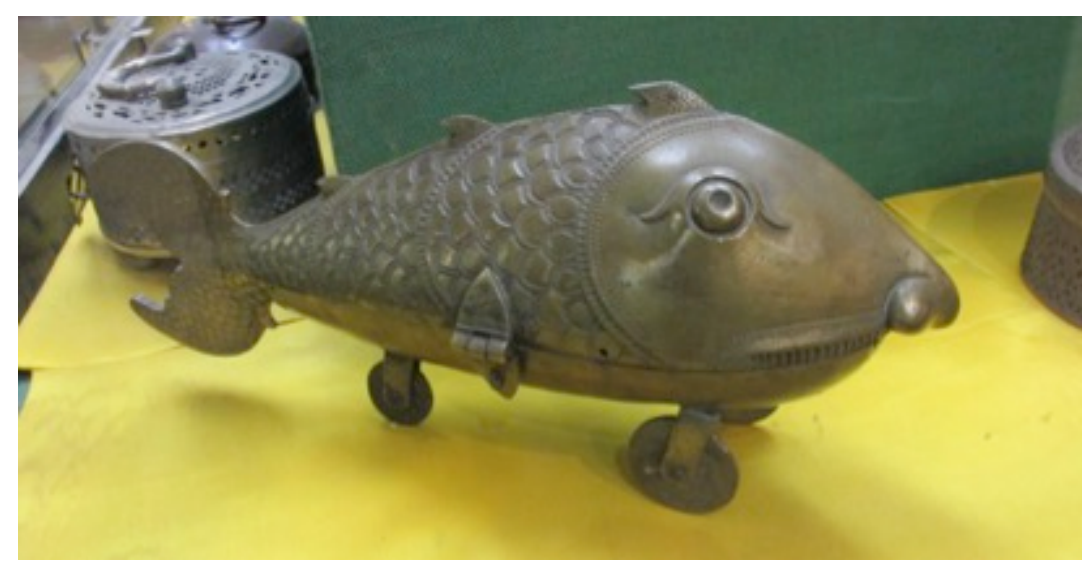

Fig. 6.5: Fish shaped Beetle Box, $18^{\text {th }}$ Century AD

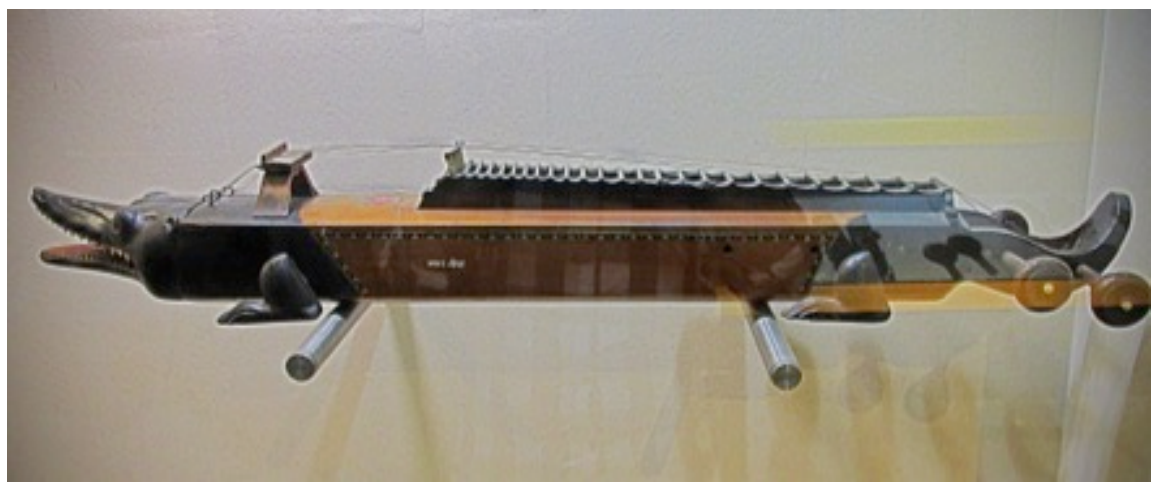

Fig. 6.6: Crocodile Lute 

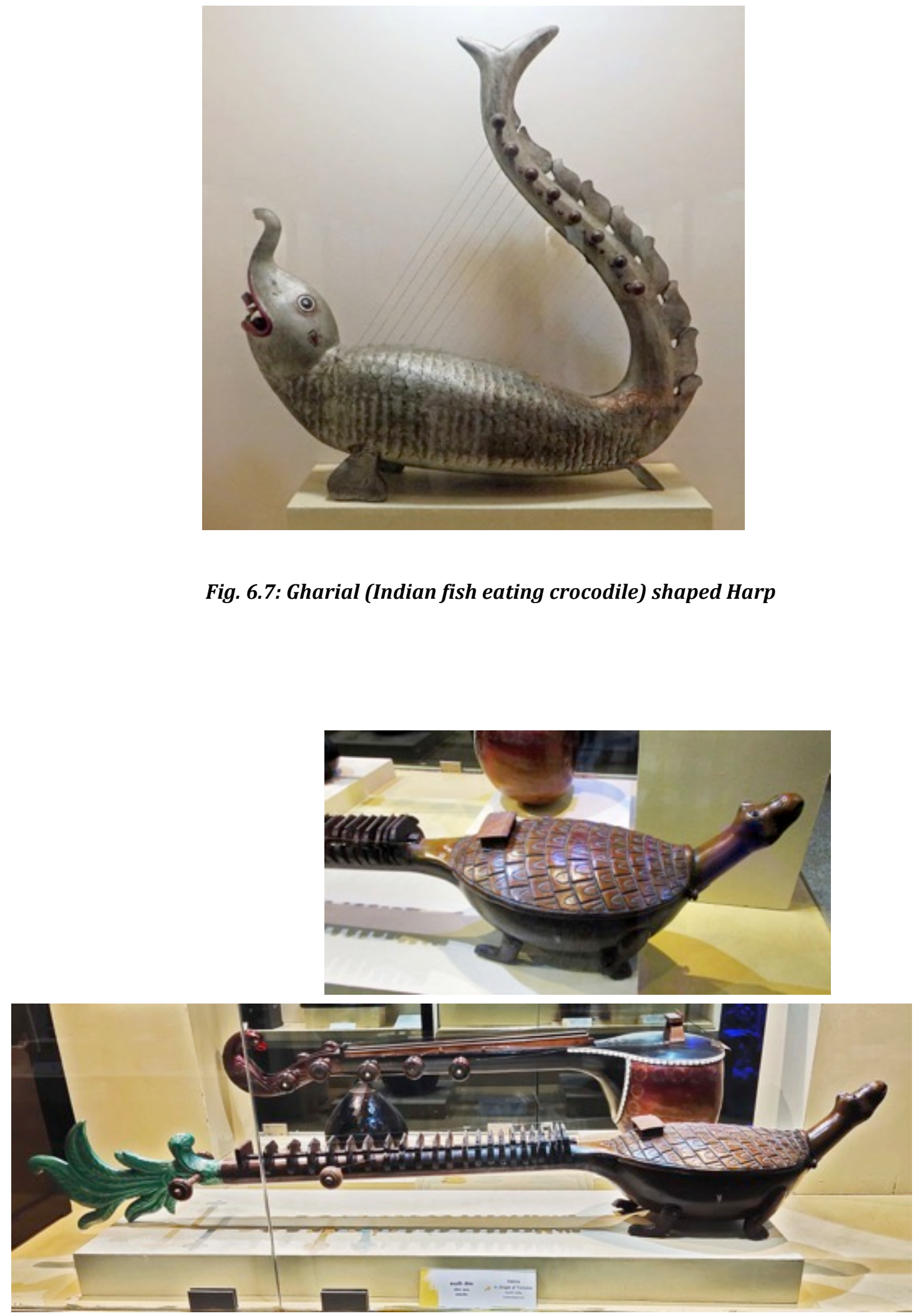

Fig. 6.8 Tortoise shaped lute 'kachchpi' - mentioned in Mahābhärata. 
2000

2001

2002

2003

2004

2005

2006

2007

2008

2009

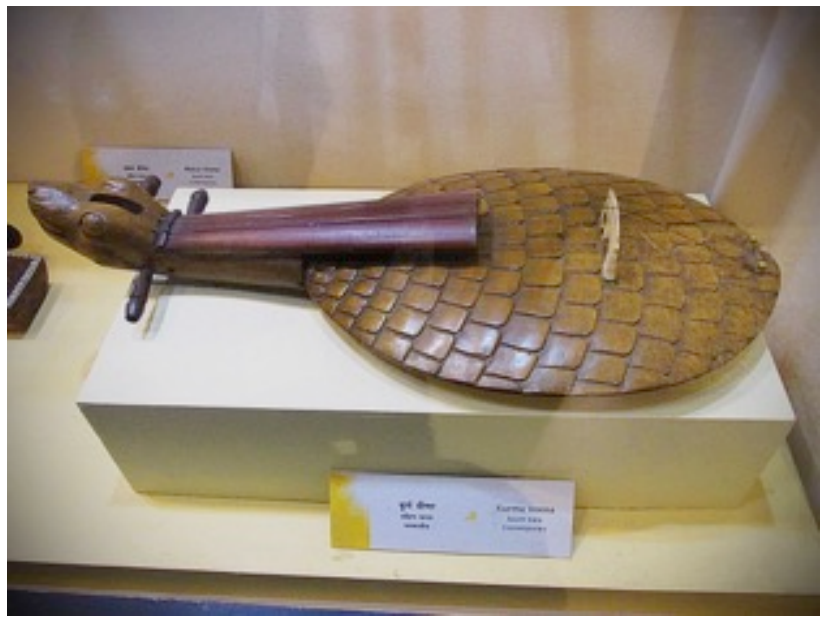

Fig. 6.9: Tortoise Fiddle
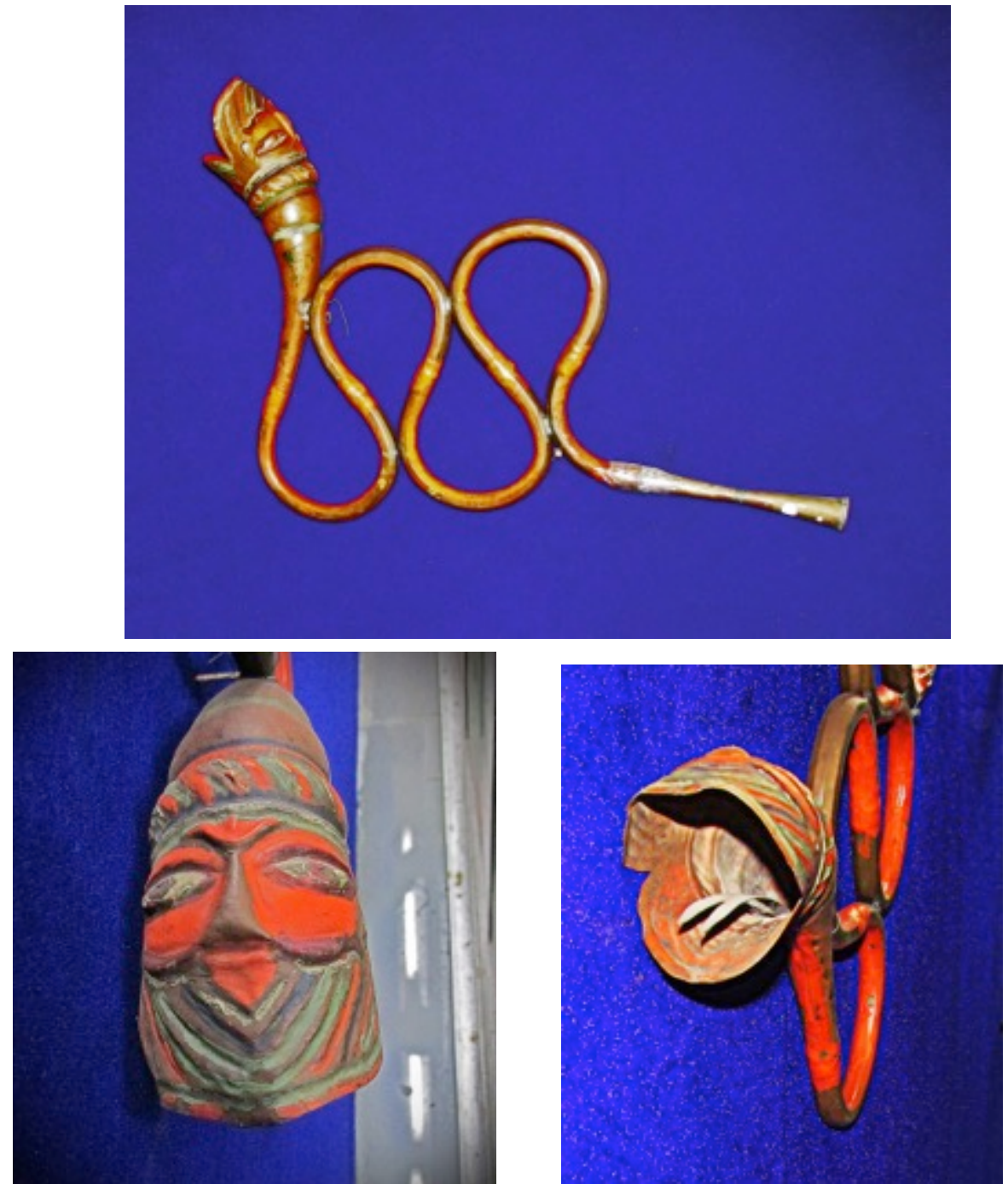

Fig. 6.10: Anthropomorphic Snake Trumpet from Rajasthan, India and details of the hood of the snake 


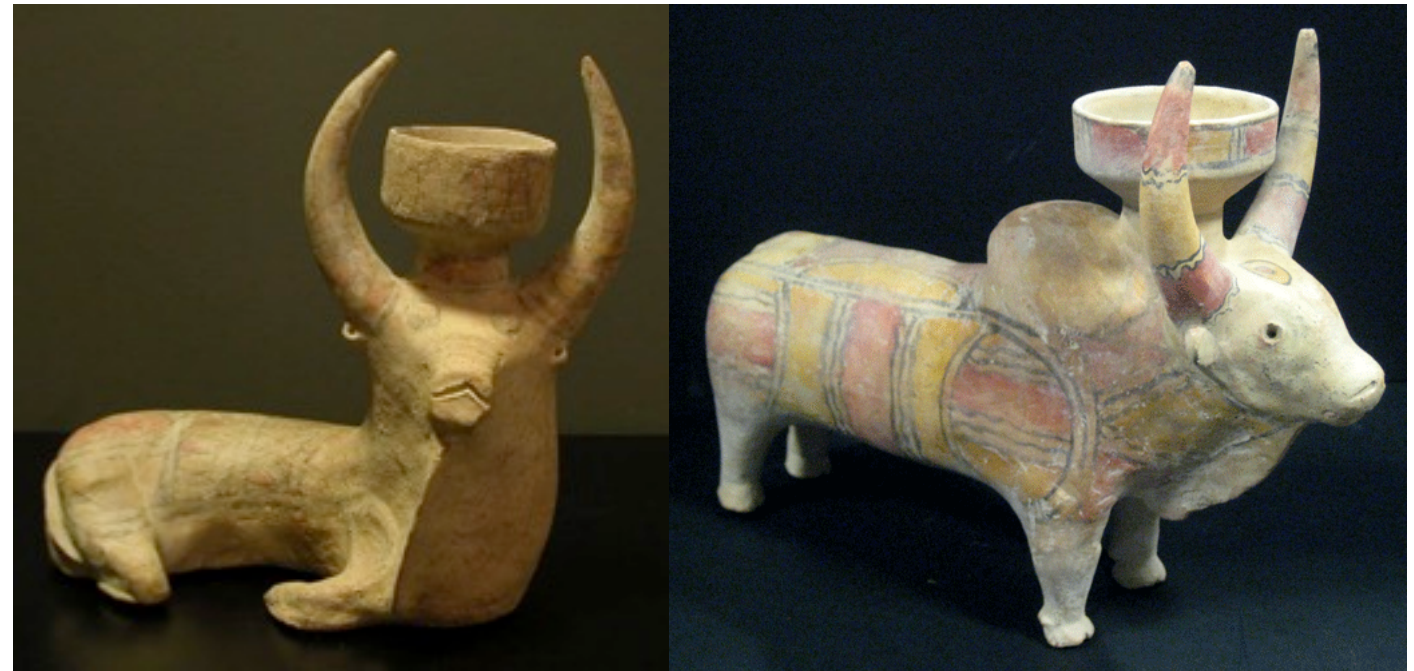

Fig. 6.11: (Above) Harappan lamps; (Below) A lamp and a hair dryer from Maharashtra, 2015 India, $18^{\text {th }}$ Century $A D$
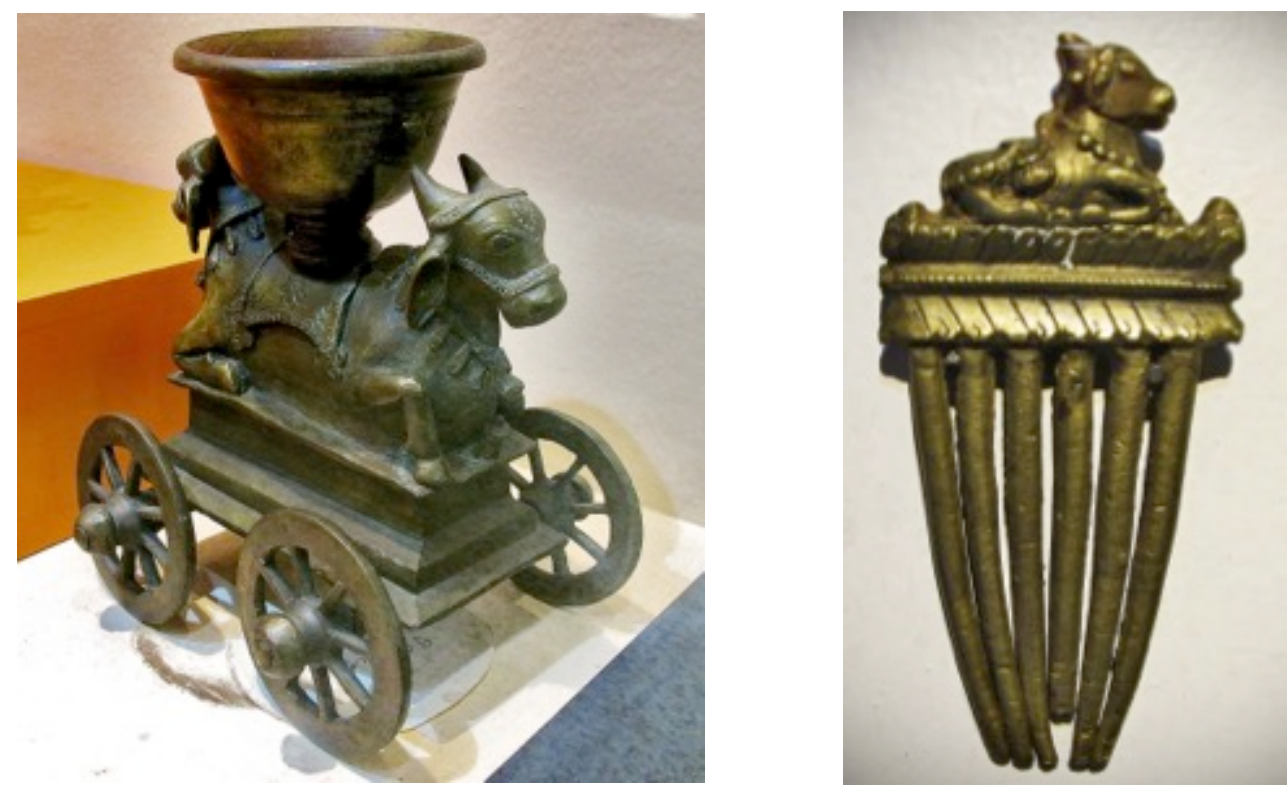

But apart from instruments that are fully zoomorphic, there are many more instruments found in India (Fig. 7) that have animal motifs or are partly animal like. In many cases an animal head (sometimes tail part too) is attached to the main body, which is shaped more conventionally, perhaps for sound or convenience of some kind. Here we see a kind of contrasting idea, the instrument becomes the body of the animal/bird instead of body of the instrument shaped like one. Similar feature is seen on Mesopotamian lyres as well. 
2029 Fig. 7- (7.1) Rudra vị̣ā, (7.2) Vichitra vịnā, (7.3) Saraswati vịnā (7.4) Swan shaped vịnā (7.5) Phet Banam, (7.6) Sārindā (7.7) drum with bulls, (7.8) Multiheaded Snake Tānpurā.

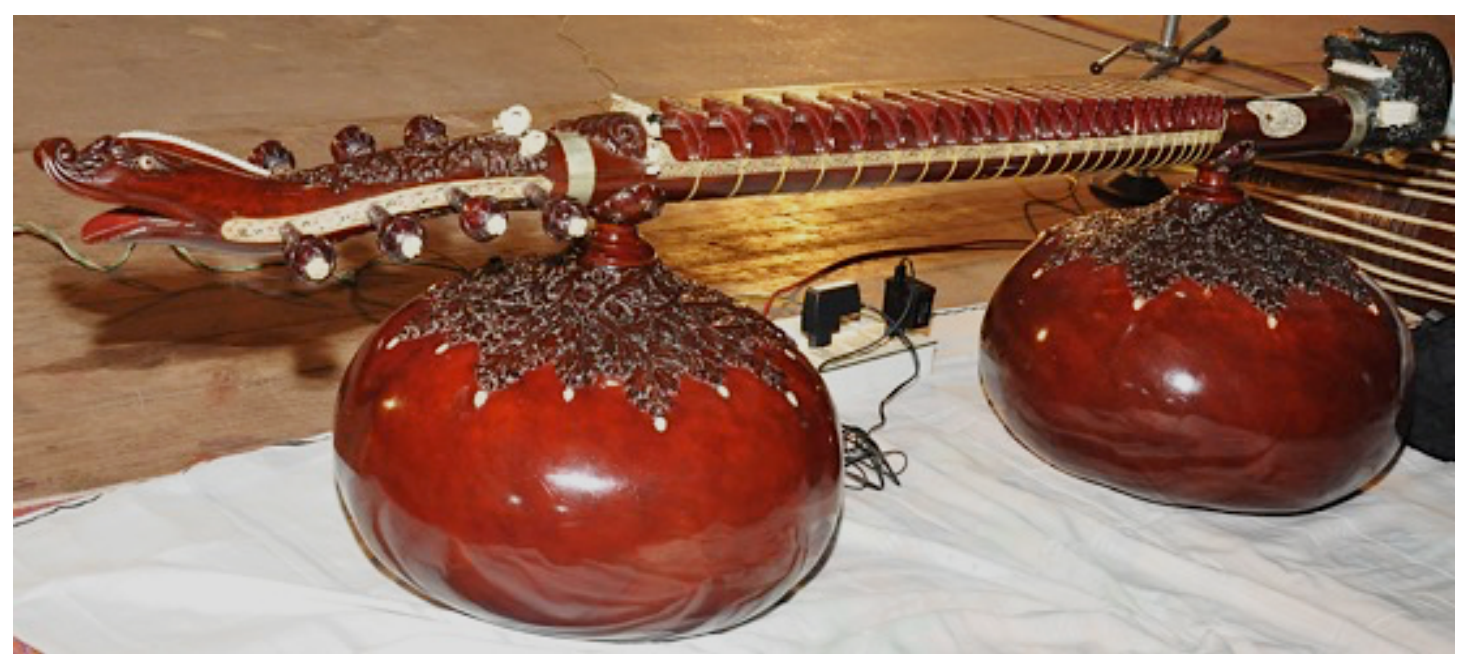

2034

2035

Fig. 7.1: Rudra vīnā with a snake's head emanating from it; mentioned in mahābhārata.

2036

2037

2038

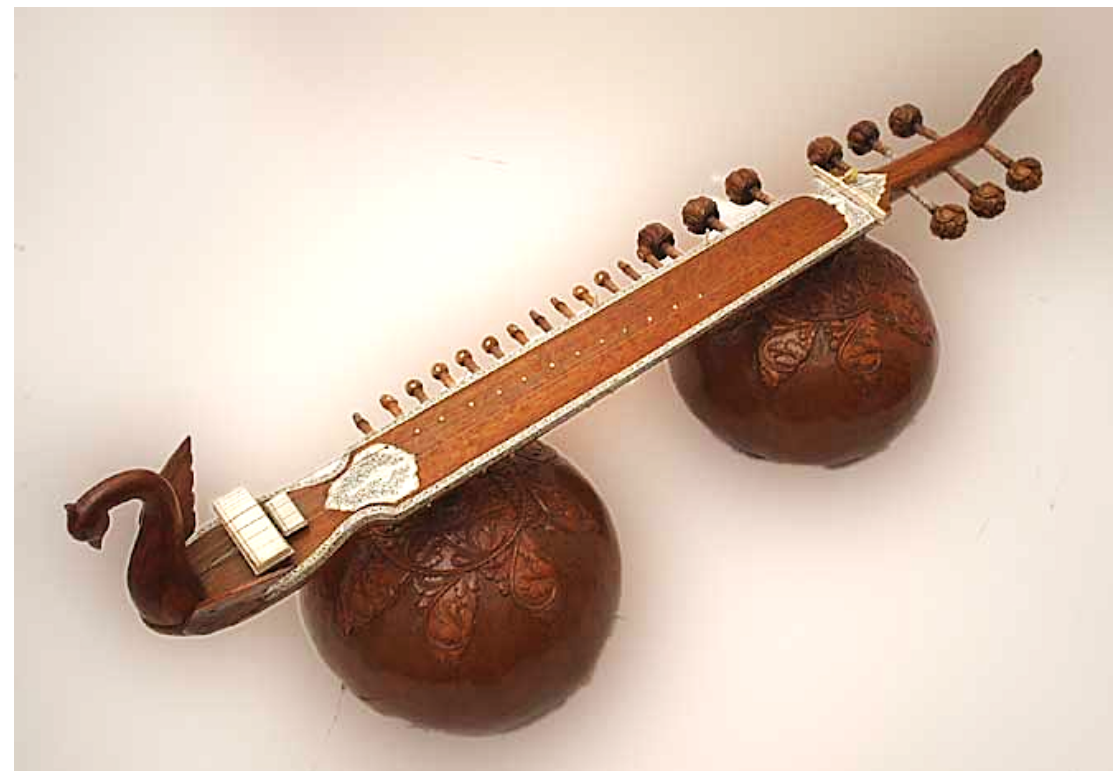

Fig. 7.2 Vichitra Veena, a fretless plucked stringed instrument played using a slide 
2043 2044 2045 2046 2047 2048

2049 2050 2051 2052 2053

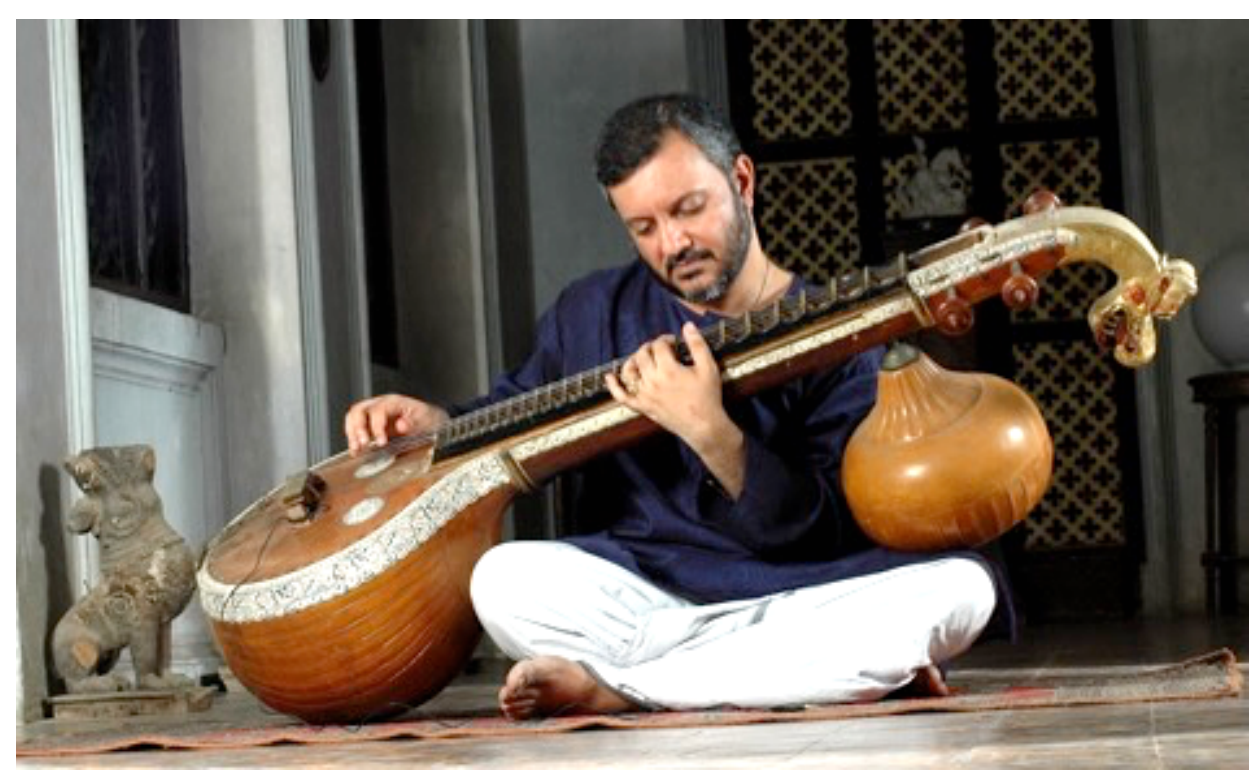

Fig. 7.3: Saraswati Veena with golden lion head

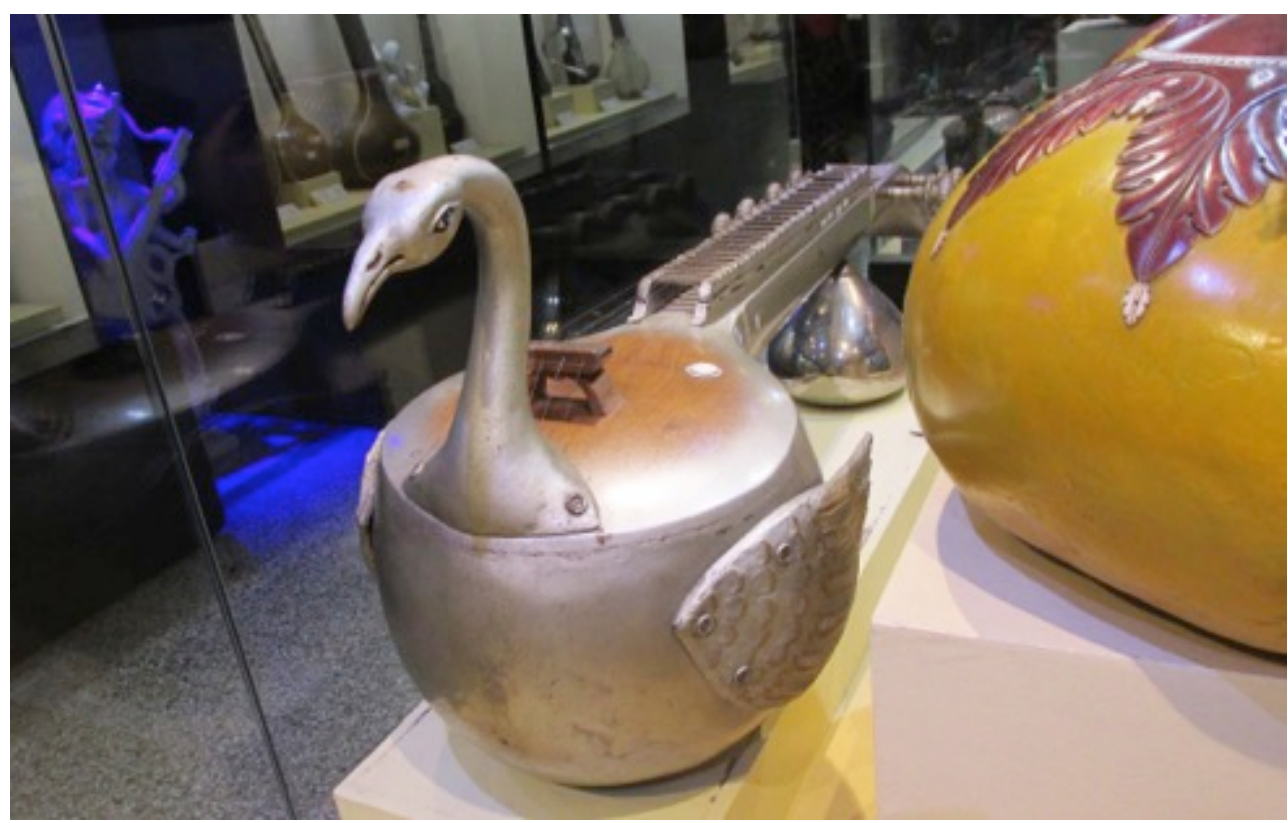

Fig. 7.4: Swan shaped lute 


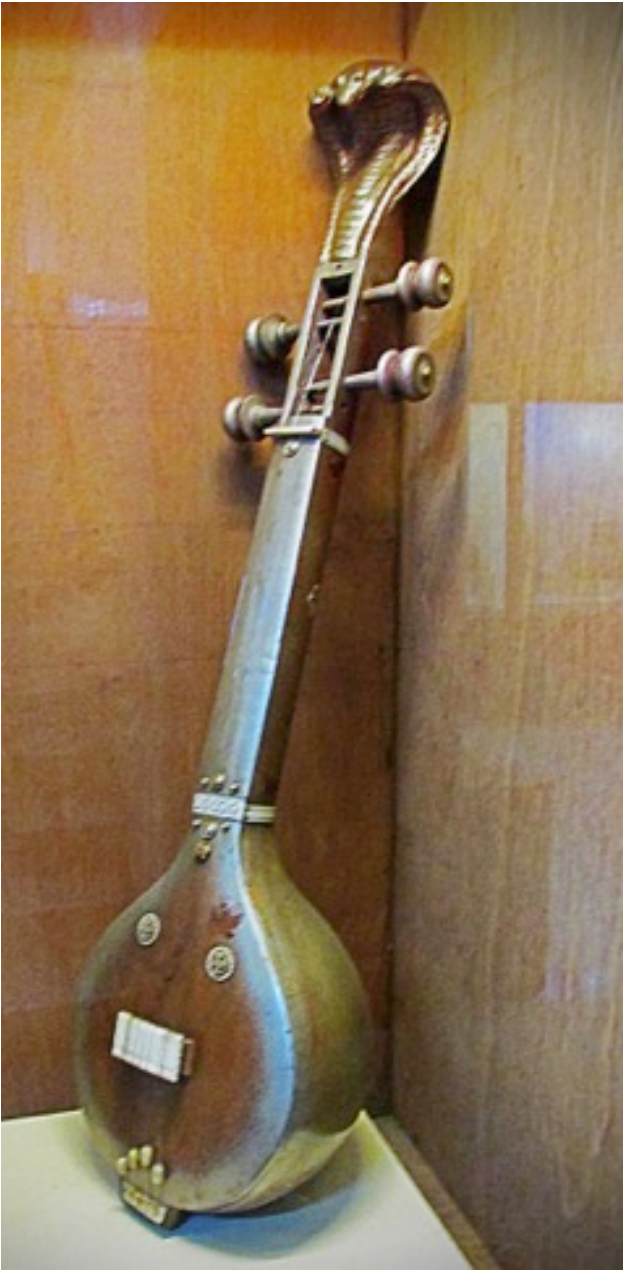

2055

2056

Fig. 7.5: Taanpura with a multi-headed snake emanating from the neck

2057

2058

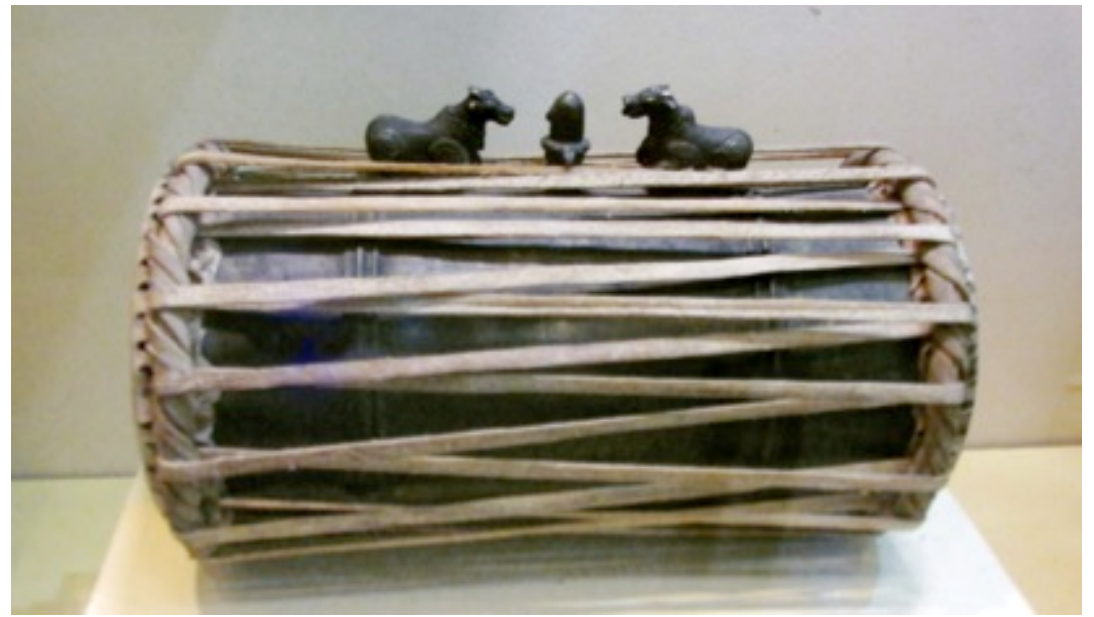

Fig. 7.6: Drum with two bull-calves and a Shiva Lingam (c.f. fig. 5 lilis) 


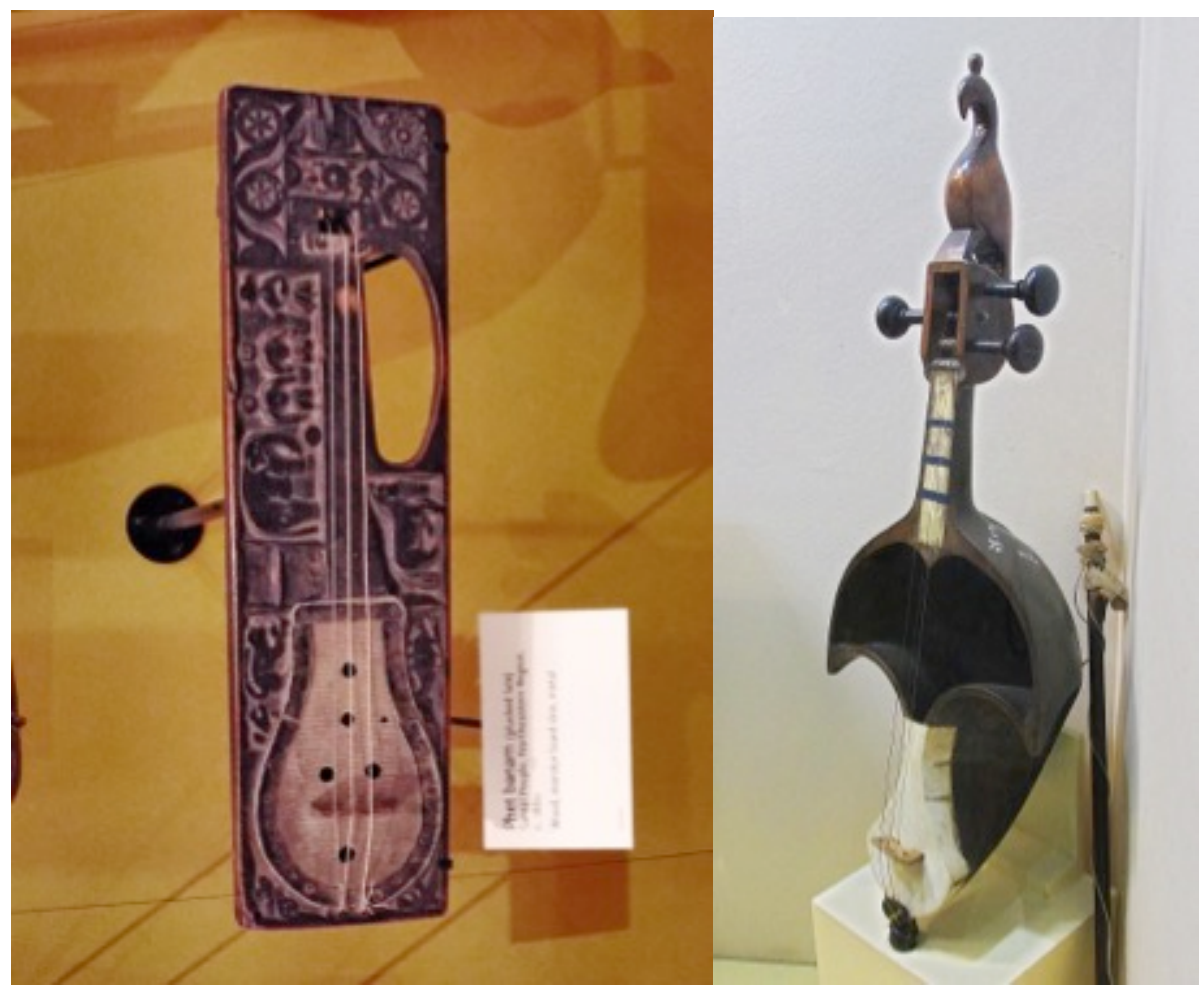

Left - Fig. 7.7: Phet banam with an assortment of animals carved on it; a fish, tortoise elephant, monkey, scorpion and horse etc. with three human figures. It is played by Santhali (an Austro Asiatic language) speaking people in northwestern region in India.

Right - Fig. 7.8 Sarinda (a bowed stringed instrument) with possibly a Himalayan Monal bird like figure attached above it. Monal is the "state bird" of Uttarakhand state in India. It is found in Afghanistan and Pakistan through the Himalayas in India, Nepal, southern Tibet, and Bhutan.

As the figures 6 and 7 show, presence of such a large variety of large-sized zoomorphic stringed instruments in India is striking and exist among speakers of both Aryan and Dravidian languages in India. It is very reasonable to think that this tradition is part of the same cultural synthesis involving animal symbolism

Apart from instruments, the notes of musical scale in India are mentioned to have originated from different birds/animals e.g. peacock, nightingale, etc. There are also many ragas-s/ragini-s (melodic frameworks), tala-s, etc. that have names derived from animals/birds. 


\section{Symbol of Harappans settled in Mesopotamia - The Bull}

Most of the round and rectangular seals found in Mesopotamia with Indus script or iconographies depict a bull and there is an almost general consensus that this big bull visible in these seals is the Indian gaur (Bos gaurus gaurus). Thus Vidale says, “(...) the Indus families living in the western commercial enclaves already recognized the gaur, one of the standard animal figures of the standard seals in the motherland, as their symbol."

\section{The "Harappan" Bull Lyre}

With this background, a very rarely depicted fully zoomorphic bull-shaped lyre in Mesopotamia becomes of great interest here (not to confuse with popular bullheaded lyres). Fig. 8 shows scene of a banquet on a cylinder seal from a grave in the Ur cemetery (PG L054). In the bottom register there are 2 figures playing clappers, a dancer (could also be a musician playing a straight clapper or a rattle), and a seated figure playing a bovine lyre. The top register shows festive banqueters. U. 11904 (Woolley 1934, pt. 1: fig. 23) (Anne Kilmer, 1998).

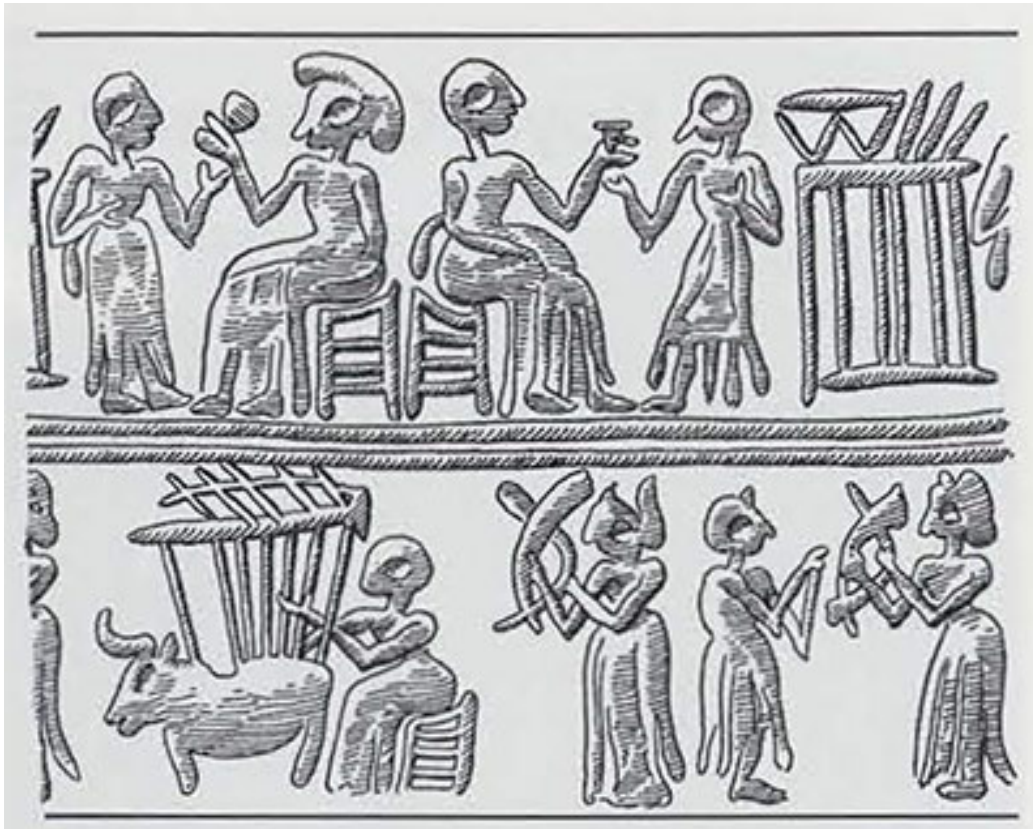

In context of the presence of perhaps many Harappan musicians in Mesopotamia,

2113 Indian tradition of zoomorphic instruments and the bull being the symbol of 
2114 Meso-Harappans, one is tempted to connect this particular lyre to them or of an 2115 Indus origin. As discussed earlier, Sumerian word algar, i.e. bull lyre corresponds 2116 to Sanskrit ājakāra, i.e. śiva-'s bull. Other instruments shown in the scene are 2117 clappers, which, as already discussed earlier in textual records, possibly reached 2118 Mesopotamia from India. (Also c.f. fish-shaped clapper in fig. 8). Moreover, there 2119 is nothing about this particular lyre that specifically shows that it cannot be 2120 Harappan in origin or inspiration, unlike other bull-headed lyres found at Ur 2121 cemetery, which have artwork that is clearly Mesopotamian in style. In fact, its 2122 realistic shape like an actual bull is distinctly congruous with Indian traditions in 2123 its inspiration. But there is still more evidence that may point towards such a 2124 conclusion.

In the course of this study, to distinguish this particular instrument from other bull-headed lyres found in Ur cemetery, it was designated "nandi" (or "nandi vinna $\left.\bar{a}^{\prime}\right)$, an epithet of śiva's bull, in accordance with the Indian tradition of naming instruments. Same term is used in this work, for the same purpose.

Note: Harps and lyres are similar instruments except that in a harp, strings are attached to the body directly from both ends or enter directly into the hollow body of the instrument. Whereas in lyres, at least some part of the total travel of the strings happens over the body, employing a bridge. But it is not necessary and in fact, unlikely that ancients differentiated them in this

\section{Animal Musicians and the Lyres of Ur Cemetery}

Primary source of animal-musician imagery, especially from the early periods in Mesopotamia, are the inlays on bull lyres found in Ur cemetery. Depiction of anthropomorphic musicians is extremely rare otherwise in that period.

Mortimer Wheeler (1960a: 90-3) included the representation of "humans disguised as animals" in his comprehensive description of the most significant of the similarities in both the cultures. Many other scholars have expressed similar thoughts. R.D. Barnett (1973) of the British Museum writes, "Perhaps such ideas of animals acting like humans, which we find in Mesopotamian art, came to Sumer with the monkey from India, the classic home of the animal fables". (On animal fables, see A. Aarne and S. Thompson, The Types of Folk Tale, 1961). This idea is further supported by the fact that, "we may have evidence of visual motifs for which we do not have a comparable text, especially in the early periods of Mesopotamia. In other words, we do not know what other stories of scorpion 
men (see below) or animal orchestras existed" (Piotr Steinkeller). Also relevant here is Max Muller's statement in "On the Migration of Fables", where he writes, "(...) it is extremely likely that fables, in particular animal fables, had their principal source in India".

Scenes on panels of these lyres are usually interpreted in relation with underworld banquet. But according to Cheng (2009), “(...) The oft-repeated underworld interpretation of these decorations has stemmed primarily from their context of discovery, the Royal Cemetery. (...) We should not let the burial context of the finds drive our interpretation of how and where they were used generally. Furthermore, these afterlife interpretations are a case of generalizing from a small sample; the panel from Great Lyre is given more prominence than perhaps it deserves."

On the other hand, in south Asia, as explained earlier, the traditions of animalmusicians and performers are part of mythology as celestial musicians and singers even in the oldest textual records found in the region e.g. the Rigveda and many other. As discussed earlier, themes that amalgamate human and animal attributes are abundant in Harappan iconography as well. It is likely that these ancient indigenous traditions may have become part of later mythology. Two of the classes of Indian traditional performers recorded in Sumerian and Akkadian texts i.e. Kinnara-s and Bhand-s (both discussed in detail above), are well known to use animal getups or disguises in their acts.

Leonard Woolley (1934) excavated remains of many lyres from the royal cemetery of Ur, Early Dynastic III period. The Lyres had a zoomorphic head protruding from the body, (mostly it is of bull but on two of them, it's probably cow, identified of the basis of presence or absence of beard like feature, respectively). One lyre has a goat like figure attached above sound box. 


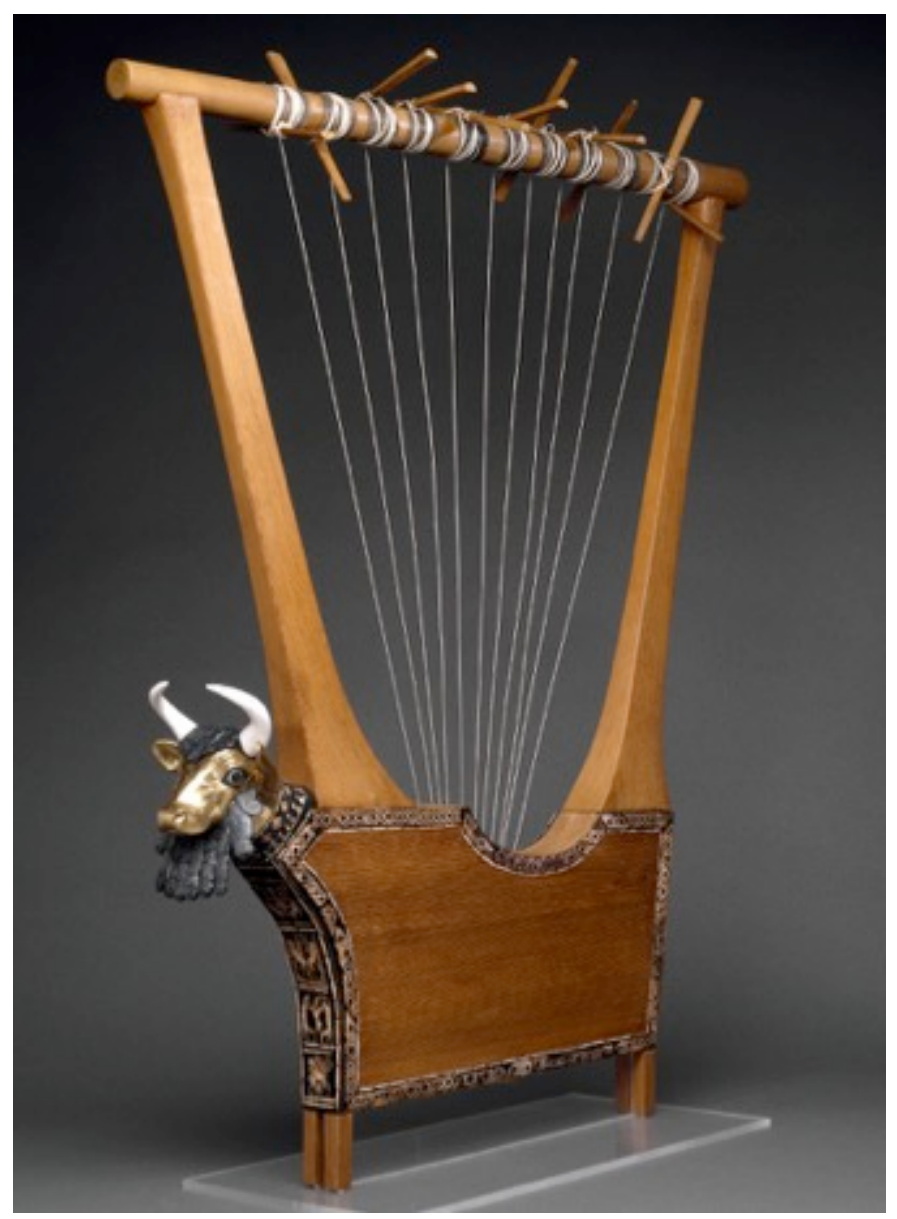

2188 Iconography on panels of the lyres is clearly Mesopotamian in style. Yet, 2189 protruding zoomorphic heads strikingly remind of the design philosophy of 2190 Indian instruments as mentioned above. Not only that, the iconography seems to 2191 depict themes that are similar to south Asian traditions, e.g. anthropomorphic 2192 musicians and more.

2194 Let us examine the panel on so-called Great Lyre and compare those images with 2195 the traditions in south Asia. It is divided in four registers (Fig. 10.1). 


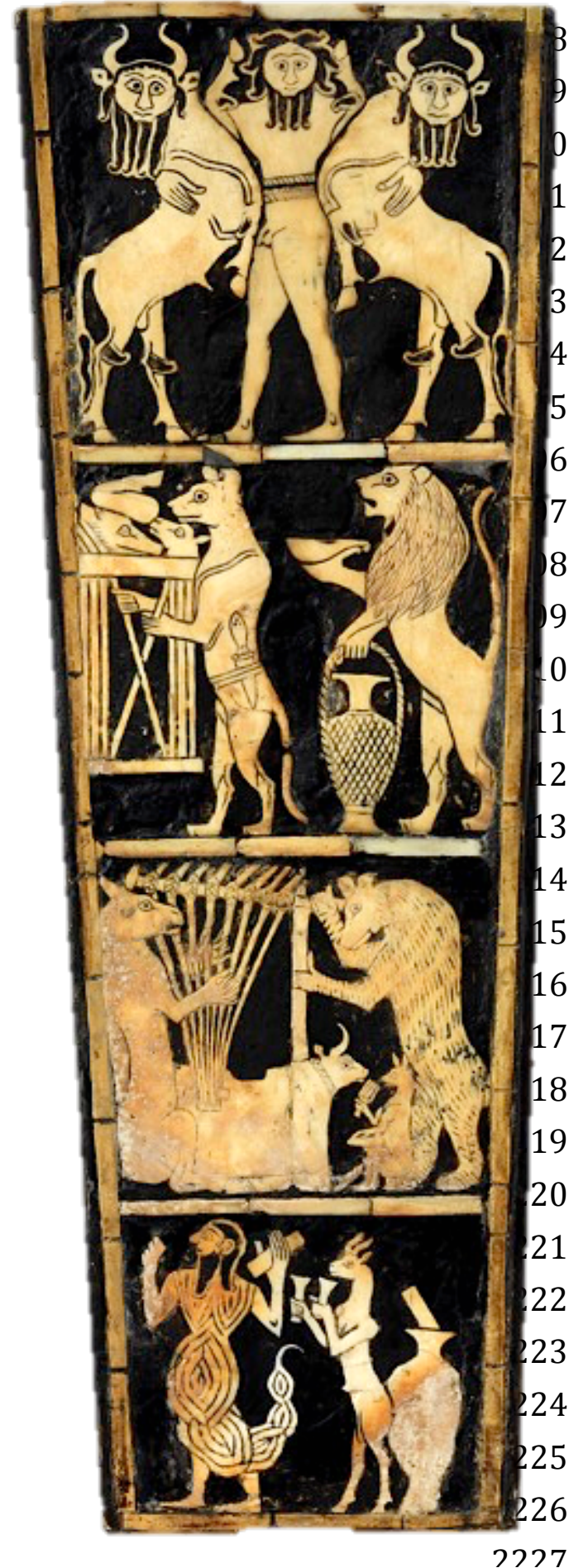

Fig. 10.1: Panel on The Great Lyre (Penn Museum B17694A)

The first register shows a scene similar to the "master of animals" that is paralleled well in both the civilization. But in this particular example, an explicitly male nude figure lovingly holds two anthropomorphic bulls in his arms. Unlike that common "combat" image, here he is a "friend of animals" or a "protector of animals". So much so that the line between human and animals itself is blurred, a trait which is characteristic to the south Asian artistic thought. While female nudity is well attested and discussed in Mesopotamia, but explicit display of masculinity is somewhat peculiar. According to Dales (1979), "neither male nudity, male obesity, nor animation are found among Sumero-Akkadian figurines of this date (Of Dice and Men, GEORGE F. DALES (1979); Ancient Cities of Indus (Edited by Gregory L. Possehl pg. 142)). While not in figurines, male nudity is still present in Mesopotamia but only in very specific contexts. One of them is of dead soldiers (probably enemies) or prisoners. But in most of those examples, it is generally part of a larger narrative or scenes and showcasing masculinity is usually not the point; nor it is given any particular prominence in 2229 many of those cases. In other context, 2230 strangely, in Early Dynastic and Akkadian periods, display of masculine nudity is 2231 mostly found in iconographies on the objects (seals or otherwise) that also 2232 feature zoo/anthropomorphic or horned human figures, musicians, priests, or 2233 water buffalo and other animal similar to panels of bull-headed lyres. Other than 2234 that, male nudity is more or less absent in Sumero-Akkadian periods. Some 
scholars have proposed that male nudity may represent foreigners, which may include not only foes but friends as well. Whereas, in south Asia, it is present in

2237 large number of figurines in Indus archaeology in both early and mature 2238 Harappan phases and on many seals as well. In some examples, 2239 anthropomorphic horned figures are shown in ithyphallic state. It is also 2240 commonly found in sculptures in many temples related to Hinduism, Jainism and 2241 Buddhism throughout historic periods in the region. śiva, who is generally 2242 considered to be one of the most ancient, widely worshipped God and the third 2243 of the Hindu Trinity, is worshipped much more commonly in the form of the 2244 lingam, or the phallus. Evidence of the lingam in India dates back to prehistoric 2245 times (2300-2800 BCE?). In his human form, in early periods (?), śiva is some 2246 times depicted in ithyphallic state.

Second register shows a couple of animals serving food and some kind of beverage, perhaps in a banquet (see word no. 47 vamśaja/banšur - table).
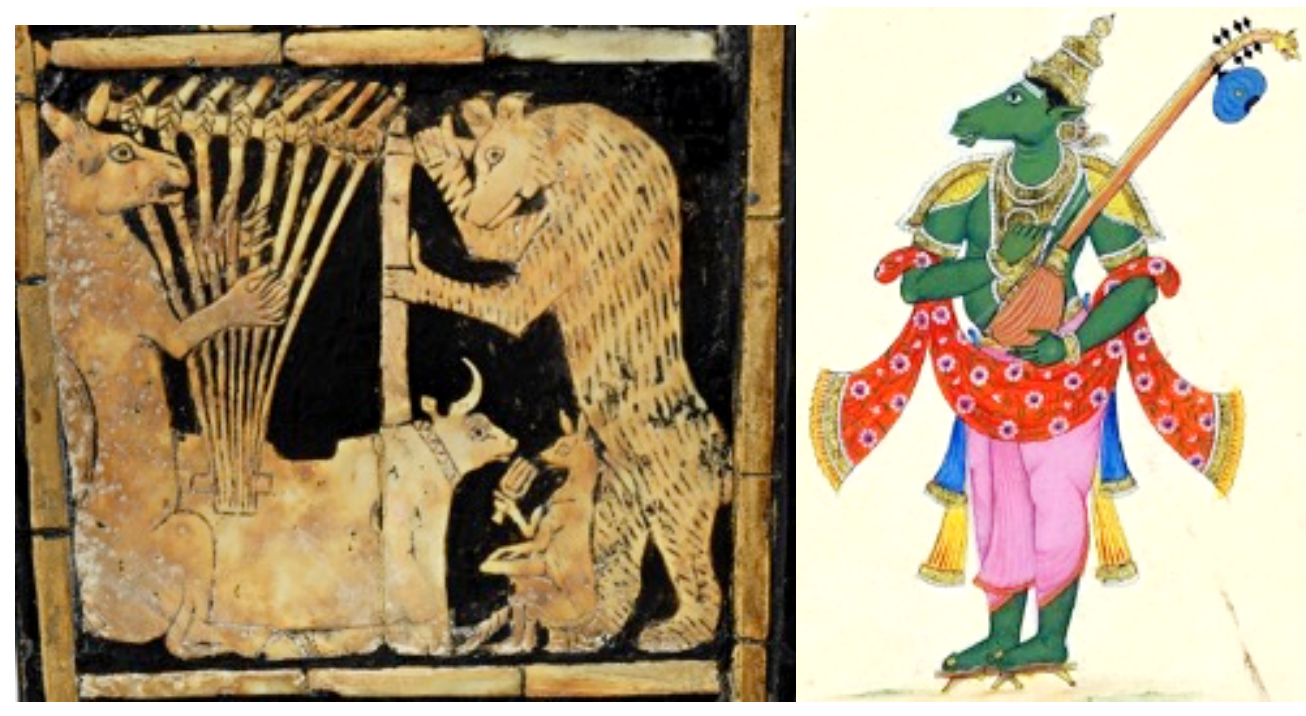

Third register (Fig 10.2) on the bull-headed lyre shows an anthropomorphic musician playing a bull-headed lyre. Another animal, a bear, is holding the instrument, some times interpreted as a dancer. A third small figure is like a fox or jackal, playing a Sistra (or Sistrum). Galpin (1937) suggested its origin in India. Similar instrument is mentioned in Sanskrit records as srșțā (सृष्टा), a stick with jingles. Fig 10.3 shows an Indian painting (1820 AD, British Museum $22612007,3005.53$ ) of highly celebrated celestial anthropomorphic musician, 2262 Tumburu, playing a lute that has a zoomorphic head attached at the end of its 
neck. He appears in both the epics i.e. Rāmāyana and Mahābhärata as well as in other texts. The painting is reasonably analogous to his description in the ancient texts. If we ignore the elements that are clearly of later origin (ornaments, clothing, general 'modernity' in the form) or the exact choice of instrument, and compare it to Mesopotamian image in fig. 10.2, then both the images seem to represent basically the same thing; i.e. "an anthropomorphic musician, playing an instrument that has a zoomorphic head attached to it". Even the choice of animal part of musician is harmonious in appearance. Discussion here is not to postulate in particular that it is in fact Tumburu depicted on Ur lyre, but the cultural synthesis behind it.

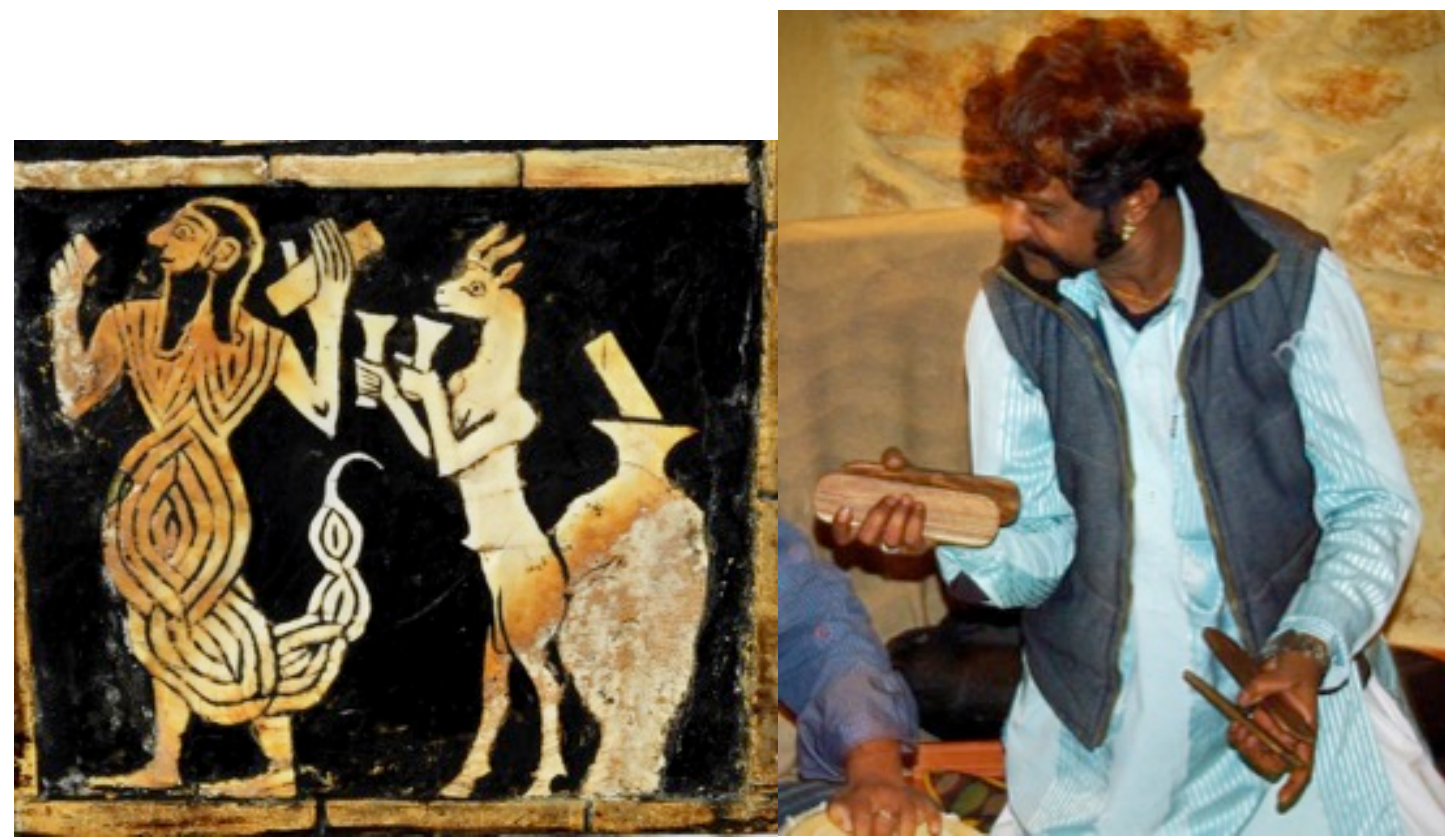

Left - Fig. 10.3: Fourth register on the panel of great lyre. Right - Fig. 10.4: A folk musician from Rajasthan, India playing a clapper (karatāla or kharatāla)

In the last one (fig. 10.3), a human-scorpion musician is playing a clapper instrument and a gazelle is playing a rattle/shaker (or serving drinks?). Exactly same variety of clappers is still played in India and Pakistan (Fig. 10.4) especially in present day Rajasthan, Sindh and Gujrat provinces where many important Harappan settlements are found. Technique of these folk musicians, who play this simple instrument today in the subcontinent, is highly sophisticated. They can play very intricate rhythmic patterns at a very fast tempo.

Other than lyres of Ur, the only attestation of animal-musicians in early periods 
in Mesopotamia is on a seal (ED II, 2650-2550 BCE), which was also found in Ur (Fig. 11) (Hansen 2003). There are two instruments clearly seen in this seal being played by these musicians ( $2^{\text {nd }}$ and $3^{\text {rd }}$ equids) i.e. an arched harp and a clapper. As discussed above, Sumerian/Akkadian words for both are very similar to their Indian names and shapes of harp and possibly clappers are represented in Indus script as well. The first equid might be playing a small lyre (or holding a jar?).

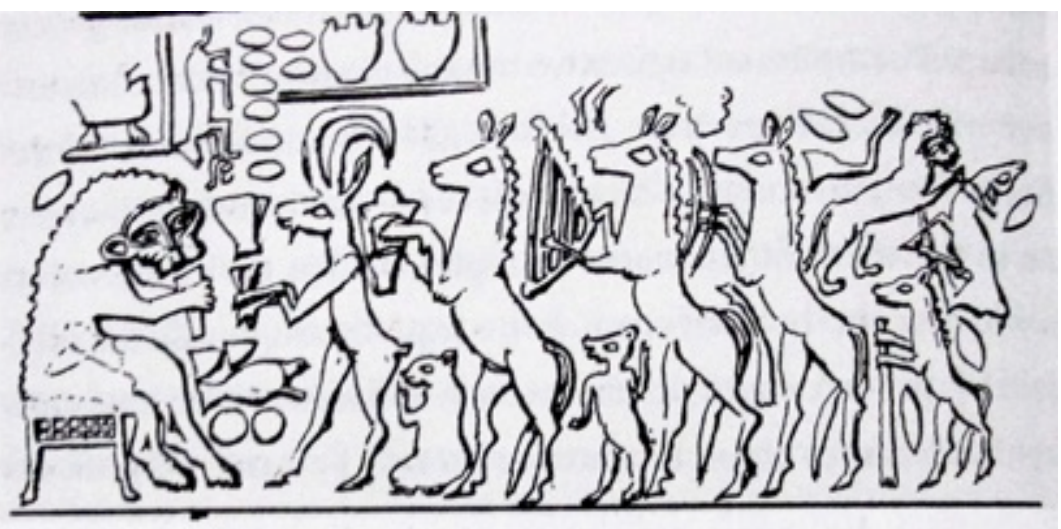

Fig. 11: Drawing of impression on clay from a cylinder seal: Ur, Early Dynastic II, 2650-2550 $B C E$

Similarities between Indian and Mesopotamian forms in the registers of this lyre and in other examples are very striking and seem unlikely to be a random coincidence. Rare presence of animal-musicians in Early Dynastic period and no evidence of existence prior to that, support Harappan influence.

Despite so many similarities, the distinctive Mesopotamian style of the decorations on Ur lyres cannot be ignored.

Many of the carnelian beads found in the graves of the main Sumerian cities or at Susa in the second half of the 3rd millennium BCE are presently interpreted as made locally by Indus craft-persons or artisans trained in an Indus technical tradition but producing shapes and decorations after the specific local demand. Vidale (2004) points out that Indus craftsmen had developed an intimate understanding of Mesopotamian culture and markets. They promptly adapted their products and trade to the fast-changing political and ideological environments of the local social and cultural evolution. Musical instruments are usually fragile and regularly require repairs. If there were so much of Harappan 
music was present in Mesopotamia as textual evidence suggest, then a respective number of instrument makers would also be needed. The "Epic of Gilgamesh" mentions a "flute of carnelian" (British Museum BM 36909, BM 37023, etc.). As Gilgamesh prays to the gods of the Netherworld, he names the gifts he is burying with Enkidu for his journey in the afterlife including a flask of lapis lazuli and a flute of carnelian (from Book VIII of the Epic, lines 144-149)(George 1999, 2003, 2003a). If such an object actually existed, even for symbolic or ritualistic purposes, it would be not very different from a larger barrel type long carnelian bead with holes note. Only Harappans had the technology to make such an object (Kenoyer?). Therefore, the possibility of involvement of Harappan craftsmen in the manufacture of musical instruments in Mesopotamia is thus, very much a tenable premise and as the evidence suggest, could be the case.

Note: Indian transverse flutes are extremely simple in construction; it is just a hollow pipe (of many sizes and materials) with holes. But the technique and virtuosity of its players, just like karatāla, is a completely different story. High-pitched variety of Indian flutes can be very small, as short as about $18 \mathrm{~cm}$ in length with a diameter of about $1.5 \mathrm{~cm}$.

These wooden lyres were richly decorated or overlaid with gold, silver, copper, lapis lazuli, mother of pearl, etc. (Kilmer 1998). Interestingly, most of these materials (as well as certain types of wood) are mentioned regularly as supplied to Mesopotamia from the Indus area or through Harappan traders in both prepared and raw forms. The particular material used in manufacturing of surviving parts of these lyres may be tested to know their origin. Moreover, the manufacturing of wooden musical instruments would not be very different from that of royal furniture, which the Indus trade centers were supplying to Mesopotamia (see above).

The excavator (Wooley) suggested that prior to this form, the bull-headed lyre could be more like a real bull with legs, etc.; and rightly so, because nandi type lyre is attested only in early periods with low occurrence. Whereas bull-headed lyres seem to be popular in Sumero-Akkadian periods, as found in art and actual remains.

Here is another example that may reiterate the possibility of Harappan participation in musical spaces in Mesopotamia - Fig. 12.1 shows the lower register of so-called "Stele of Music" found in Telloh (ancient Girsu) dating to the reign of Gudea (2100-2000 BCE). It has a seated musician playing on a large lyre with a small but realistic figure of a short-horned bull attached above sound box. 
Interestingly, the bull appears quite similar to the ones seen on "Indus style" seals found in Mesopotamia, and as found in Indus Valley.

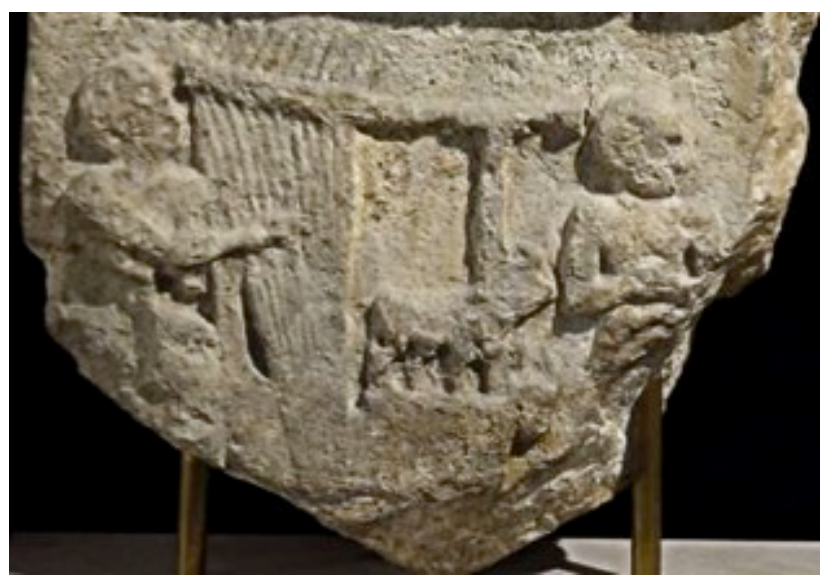

Fig. 12.1 Lower register of "The Stele of Music"

All of the above-presented evidence strongly suggests that bull-headed lyres of Ur cemetery could be a hallmark of fusion of Harappan and Mesopotamian cultures. Tradition of zoomorphic instruments of south Asia and specially nandi type fully zoomorphic bull lyre may had been their inspiration. But they were manufactured in Mesopotamia, possibly by acculturated Harappan artists and artisans in local styles. In other words, these lyres could be Harappan in inspiration but Mesopotamian in presentation.

\section{The bridge}

A bridge is a device that supports the strings on a stringed musical instrument and transmits the vibration of those strings to another structural component of the instrument-typically the soundbox. The bridge of these lyres is quite wide and appears flat on the top. Such wide and flat (or slightly curved) bridge is widely found in Indian instruments (see figures 6 and 7 above) including most prominent (and ancient) ones like Rudri, Saraswati, Kachchapi and many other vinna -s (many of which are fully or partially zoomorphic) and continuing till modern Tānpura and Sitar. This bridge is the reason behind that certain twang in the tone of these instruments (C. V. Raman, 1905). Indian smaller lutes (Ektara, Dotar, Sarod, etc.) and bowed instruments (Rāvanhast, Sārangi, Sārinda, Isrāj, etc.) mostly have a bridge of thinner variety. 


\section{Dilmun connection}

Another evidence suggesting Indus origin of this fully zoomorphic lyre, is found on a 'Gulf seal' from Falaika in Bahrain (Fig. 13), which was of course en route emporium through which the Harappan trade was carried out with Mesopotamia after the direct trading had come to a stop somewhere around 2100 BCE. A strong Harappan impact is seen in the archaeological records from that period. The area is usually identified as Dilmun. According to Steffen Terp Laursen (2010) "The innovative group of risk-taking entrepreneurs that were instrumental in transmitting Indus Valley sealing, writing and weight technology into Dilmun culture must at first have been composed of break- away Harappans (c.2100 BC), followed by a combination of Dilmunite and acculturated Harappan merchants (c.2050 BC)".

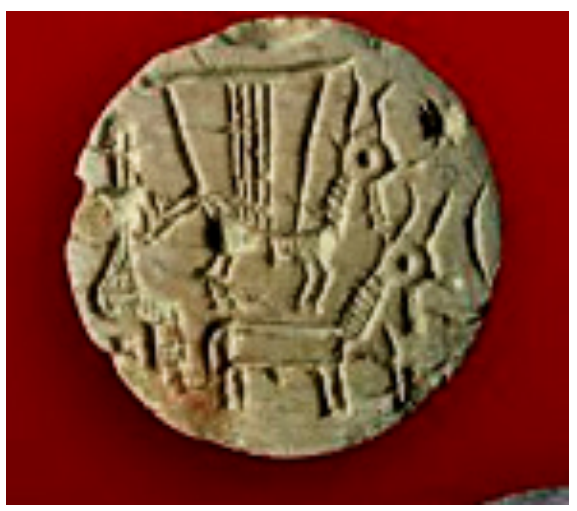

Fig. 13

But in such a case, assuming that Nandi reached Mesopotamia with Harappans, did these "break-away Harappans" bring their beloved instrument here too? Fig. 13 shows a round seal from Falaika, which depicts a bull and a musician playing nandi like instrument. Presence of this particular instrument in Dilmun does support its Indus origin, but not exclusively so, since Dilmun had relations with Mesopotamia too since probably 3000 BCE. However, circumstantial evidence supports its origin in Indus valley because the attestation is from the period around 2000 BCE when strong Harappan influence is recorded and Harappans were trading with Mesopotamia exclusively through Dilmun. Whereas, nandi in Mesopotamia is attested only in early periods when Harappan direct trade started to appear in Mesopotamia and afterwards it is only Ur style bull-headed lyres seen in iconography. In other words, this instrument is attested in

2418 Mesopotamia and Bahrain in separate periods but in both cases, coinciding with the time when Harappan contact start to appear. 


\section{CONCLUSIONS}

Just as concluded by During Casper (1979) and others, the textual and archaeological data is suggestive of a strong Harappan cultural impact in music and performance spheres along with economic domains in Mesopotamia already established by Early Dynastic periods and which intensified in later periods of their acquaintances. Impact in music seems to be very strong on the basis of percentage of similar words. The spread of the cultural elements may have ultimately helped, perhaps greatly, in strengthening the trade or they even possibly became active contributor to it.

The idea of anthropomorphic musicians and zoomorphic musical instruments may have reached to Mesopotamia from India, the classic home of animal fables. One such example could be a lyre that was realistically shaped like a bull. Those ideas may have evolved there and amalgamated with local styles - in forms of the lyres found in Ur cemetery - with possible involvement of acculturated Harappan artisans in their manufacturing. Study on materials used in manufacture of surviving specimen may help to know if Harappan traders supplied some of the raw material.

There is much work to be done to better understand the textual data but this data in conjunction with independent archaeological and circumstantial evidence suggest that there is a strong possibility that Harappans who travelled, traded and settled in Mesopotamia may have spoken a form of Sanskrit or it was the lingua franca of the Indus region.

About the author: Awarded with Homi Bhabha fellowship, author is a composer, orchestrator and music producer with extensive experience in working with musicians and instruments from all around the world. He is an independent musicologist and founded "Songs of Mystery Research Project" in 2011, an ongoing research on music in Indus valley civilization and subsequent periods in Indian subcontinent. 


\section{Acknowledgements}

I'm very grateful to Homi Bhabha Fellowships Council, without their generous support this paper wasn't possible.

I would like to express my deepest gratitude to Dr. R. S. Bisht for his valuable and patient guidance, as well as for detailed examination and editing of the manuscript. My earnest thanks to Dr. Mayank Vahia for generously allowing me his time to discuss various aspects and providing useful critique of the work.

Very special thanks to Prof. S. M. Chitre for his enthusiastic encouragement and help in improving the language.

I would also like to express my profound gratitude to Dr. Aravind Jamkhedkar, Prof. Vasant Shinde, Dr. Kirit Mankodi, (Late) Mr. Kersi Lord and Mr. Avinash Oak for their guidance and support. I would also thank Raja Dinkar Kelkar Museum and Rajasthan Sangeet Natak Akademy Folk Art Museum for some of the illustrations used in this paper.

Finally, I wish to thank my family for their never-ending support and assistance throughout my journey, for which I shall remain forever indebted.

\section{References}

\section{Dictionaries}

Monier Williams Sanskrit Dictionary

Electronic Pennsylvania Sumerian Dictionary (ePSD)

The Assyrian Dictionary of the Oriental Institute of the University of Chicago (CAD)

Agrawala, V. S. (1952). Ancient Indian Flora in the Ashtadhyayi of Panini.

Beck H.C. (1933) “Etched carnelian beads.” Antiquaries Journal, XIII, pp. 384-398.

Bhan K.K., J.M. Kenoyer \& M. Vidale (1994) "Harappan Technology: Theoretical and

Methodological Issues.” Man and Environment, XIX, 2, 141-157. 
Carter R. (2002a) "Prehistoric navigation and exchange in the Persian Gulf." Paper presented at the International Congress "Early Navigation and Trade in the Indian Ocean," Ravenna, 5 July 2002.

Carter R. H. Crawford (2002b) "The Kuwait-British Archaeological Expedition to As-Sabiyah: Report on the Third Season's Work.” Iraq, LXIV, pp. 1-13.

Casanova M. (1997) Le lapis-lazuli dans l'Orient Ancien: gisements, production, des origines au debut du second millenaire avant J.-C. Doctorat, Universite de Paris I, Pantheon, Sorbonne (2 vols.).

Chakrabarti D.K. (1982) “'Long-barrel-Cylinder' Beads and the Issue of Pre-Sargonic Contact between the Harappan Civilization and Mesopotamia." In G.L. Possehl (ed.) Harappan Civilization: a Contemporary Perspective. Delhi, 265-270.

Chakrabarti D.K. (1990) The External Trade of the Indus Civilization. New Delhi.

Cleuziou S. \& M. Tosi (2000) "Ra's al-Jinz and the Prehistoric Coastal Cultures of the Ja'laan." The Journal of Oman Studies, 11, pp. 19-73.

Collon D. (1977) “Ivory.” In J.D. Hawkins (ed.) Trade in the Ancient Near East. London, pp. 219-222.

Collon D. (1990) Near Eastern Seals. University of California/British Museum, Berkeley.

Deutscher, Guy (2007), Syntactic Change in Akkadian: The Evolution of Sentential Complementation, Oxford University Press US, pp. 20-21

Dikshit M.G. (1949) Etched Beads in India. Poona. During Caspers E.C.L. (1971) "Etched Carnelian Beads." Bullettin of the Institute of Archaeology, 10, 83-98.

Dumbrill, Richard (2005) “The Musicology and Organology of the Ancient Near East”, second edition. Victoria, Canada.

Dumbrill, Richard (2017) “The Truth about Babylonian Music" Near Eastern Musicology Online 46 |2017-08| p. 91-121

During Caspers E.C.L. (1982) "Harappan Trade in the Arabian Gulf in the Third Millennium B.C." Mesopotamia, VII, 167-191.

Foster B. (1995) From distant days... Myths, tales and poetry from ancient Mesopotamia. Bethesda.

Franke-Vogt U. (1991) "The Glyptic Art of the Harappa Culture.” In M. Jansen, M. Mulloy \& G. Urban (eds.) Forgotten cities on the Indus. Mainz, pp. 179-187.

Franke-Vogt U. (1992) "Inscribed Objects from Mohenjo-Daro: Some Remarks on Stylistic Variability and Distribution Patterns.” In C. Jarrige (ed.) South Asian Archaeology 1989. Madison, 103-118.

Gadd C.J. (1932) "Seals of Ancient Indian styles found at Ur." Proceedings of the 
British Academy, XVIII, pp. 191-210.

Galpin, Francis W. (1937), "The Music Of The Sumerians and Their Immediate Successors: The Babylonians \& Assyrians" Cambridge At The University Press

George, A. R. (1999). What's new in the Gilgamesh Epic?, Bulletin of the Canadian Society for

George, A. R. (2003). The Babylonian Gilgamesh epic - Introduction, critical edition and cuneiform texts, Volume 1.

George, A. R. (2003a). The epic of Gilgamesh: The Babylonian epic poem and other texts in Akkadian and Sumerian, Reprint edition, 67-68 Penguin.

Glassner J.-J. (2002) “Dilmun et Magan: Le Peuplement, l'Organisation Politique, la Question des Amorrites et la Place de l'Ècriture. Point de Vue de l'Assyriologue.” In S. Cleuziou, M. Tosi \& J. Zarins (eds.) Essays on the Late Prehistory of the Arabian Peninsula. Roma, pp. 337-381.

Possehl, Gregory L. (2006), “Shu-ilishu’s Cylinder Seal” Expedition, Volume 48/Issue 1/2006 pp. 42 43

Hansen, Donald P. (2003), "Art of the Early City States" in Joan Aruz, Ronald Wallenfels (eds.) "Art of the Ancient Cities - The Third Millennia B.C. from the Mediterranean to the Indus".

Heimpel W.L., L.Gorelick \& A.J.Gwinnet (1988) "Philological and archaeological evidence for the use of emery in the Bronze Age Near East.” Journal of Cuneiform Studies, 40/2, 195-210.

Inizan M.-L. (2000) "Importation de cornalines et agates de l'Indus en Mésopotamie. Le cas de Suse et Tello.” In V. Roux (ed.) Cornaline de l'Inde. Des pratiques techniques de Cambay aux techno-systémes de l'Indus. Paris, 473-502.

Joshi J.P. \& A. Parpola (1987) Corpus of Indus Seals and Inscriptions. 1. Collections in India. Helsinki.

Kenoyer J.M. (1997) "Trade and technology of the Indus Valley: new insights from Harappa, Pakistan.” World Archaeology, 29/2, 262-280.

Kenoyer J.M. (1998) Ancient Cities of the Indus Valley Civilization. Karachi.

Kenoyer J.M. (in print) "Indus and Mesopotamian Trade Networks: New Insights from Shell and Carnelian Artefacts.” In E. Olijdam (ed.) E. During Casper's Memorial Volume.

Kenoyer J.M., K.K. Bhan \& M. Vidale (1994) "Carnelian Bead Production in Khambhat, India: an Ethnoarchaeological Study.” In B.Allchin (ed.) Living Traditions. Studies in the Ethnoarchaeology of South Asia. New Delhi, pp. 281-306.

Kenoyer J.M. \& M. Vidale (1992) “A New Look to the Stone Drills of the Indus Tradition.” In P.B. 

III, Material Research Society, Pittsburgh, pp. 495- 518.

Kenoyer J.M., M. Vidale \& K.K. Bhan (1991) "Contemporary Stone Bead Making in Khambat, India: patterns of craft specialization and organization of production as reflected in the archeological record." World Archaeology, 23 (1), pp. 44-63.

Kenoyer J.M. (2006a) "Cultures and Societies of the Indus Tradition”, 28

Kenoyer J.M. (2006b) "The Origin, Context and Function of the Indus Script: Recent Insights from Harappa" in Osada Toshiki, Hase Noriko (eds.) Proceedings of the Pre-Symposium of RIHN and $7^{\text {th }}$ ESCA Harvard-Kyoto Roundtable

Kenoyer J.M. (2010) "Master of Animals and Animal Masters in the Iconography of the Indus Tradition" in Derek B. Counts and Bettina Arnold (eds.) "The Master of Animals in Old World Iconography" pp. 37

Kenoyer J. M., Price, T. Douglas, Burton James H. (2013) "A new approach to tracking connections between the Indus Valley and Mesopotamia: initial results of strontium isotope analyses from Harappa and Ur" Journal of Archaeological Science 40 (2013) 2286-2297

Kilmer, Anne Draffkorn (1998) “The Musical Instruments from Ur and Ancient Mesopotamian

Krishna, S. and S. Ramaswami. 1932. Calorific values of some Indian woods. Forest Bulletin No. 79, (New Series). Chemistry, Government of India, Central Publication Branch, Calcutta.

Kuiper, F. B. J. (1955) "Rigvedic loan-words". In: O. Spies (ed.) Studia Indologica. Festschrift für Willibald Kirfelzur Vollendung seines 70. Lebensjahres. Bonn: Orientalisches Seminar.

Kuiper, F. B. J. (1991) “Aryans in the Rigveda”. Amsterdam-Atlanta: Rodopi.

Lahiri N. (1992) The Archaeology of Indian Trade Routes (upto c. 200 BC). New Delhi.

Lamberg-Karlovsky C.C. (1972) “Trade Mechanisms in Indus-Mesopotamian Interrelations.” Journal of the American Oriental Society, 92, 2, April-June 1972, 222-229.

Laursen, Steffen Terp (2010) "The westward transmission of Indus Valley sealing technology: origin and development of the 'Gulf Type' seal and other administrative technologies in Early Dilmun, c.2100-2000 BC”. Arabian archaeology and epigraphy, 2010: 21: 96-134.

Ligabue G. \& S. Salvatori (n.d.) Bactria, an ancient oasis civilization from the sands of Afghanistan. Venice.

Lombardo G. (1988) “Etched Beads' in Cornalina.” In G. Lombardo (ed.) Perle Orientali”. Tradizione antica e artigianato moderno nella lavorazione delle pietre semipreziose in Medio Oriente. Museo 
Nazionale d'Arte Orientale, Roma, 85-90.

2637

2638

2639

2640

2641

2642

2643

2644

2645

2646

2647

2648

2649

2650

2651

2652

2653

2654

2655

2656

2657

2658

2659

2660

2661

2662

2663

2664

2665

2666

2667

2668

2669

2670

2671

2672

2673

2674

2675

2676

2677

2678

2679

2680

2681
Mahadevan, Iravathan (1977) “The Indus Script. Text, Concordance And Tables”, Memoires of the Archaeological Survey of India No. 77.

Mackay E.J.H. (1933) “Decorated Carnelian Beads.” Man, XXXIII, pp. 143-146.

Mackay E.J.H. (1937) "Bead Making in Ancient Sind.” Journal of the American Oriental Society, 47, 1-5.

Mackay E.J.H. (1938) Further Excavations at Mohenjo-Daro. New Delhi.

Mackay E.J.H. (1943) Chanhu-Daro Excavations 1935-36. New Haven.

Marshall Sir J. (1931) Mohenjo-daro and the Indus Civilization. London.

Meadow R.H. \& J.M. Kenoyer (2000) “The 'Tiny Steatite Seals' (Incised Steatite Tablets) of Harappa: Some Observations on their Context and Dating.” In M. Taddei \& G. De Marco (eds.) South Asian Archaeology 1997. Rome, pp. 321-340.

Meadow R.H., J.M. Kenoyer \& R. Wright (1999) Harappa Archaeological Research Project. Harappa Excavations 1998. Report submitted to the Director General of Archaeology and Museums, Government of Pakistan, Karachi. March 30, 1999.

Meadow R.H., J.M. Kenoyer \& R. Wright (2001) Harappa Archaeological Research Project. Harappa Excavations 2000 and 2001. Report submitted to the Director General of Archaeology and Museums, Government of Pakistan, Karachi. December 2001.

Murray, Neil (2012). Writing Essays in English Language and Linguistics: Principles, Tips and Strategies for Undergraduates. Cambridge University Press. pp. 147

Parpola, A. (2015) The Roots of Hinduism: The Early Aryans and the Indus Civilization, Oxford University Press

Parpola A. (1994) "Harappan Inscriptions. An Analytical Catalogue of the Indus Inscriptions from the Near East.” In P. Mortensen (ed.) Qala'at al-Bahrein. Volume 1. The Northern City Wall and the Islamic Fortress. Aarhus, pp. 304-492.

Parpola S., A. Parpola \& R.H. Brunswig, Jr. (1977) “The Meluhha Village. Evidence of acculturation of Harappan traders in the late Third Millennium Mesopotamia.” Journal of Economic and Social History of the Orient, 20, 129-165.

Parpola, Asko et al. 1969. Decipherment of the Proto-Dravidian Inscriptions of the Indus Civilization, A First Announcement. (The Scandinavian Institute of Asian Studies, Special

Publications, 1) Copenhagen: The Scandinavian Institute of Asian Studies. 

Mans, France.

Pearson, R. S. and H. P. Brown. 1932. Commercial timbers of India. Volume 1. Government Press,

Publication branch, Calcutta. p 352-356.

Pettinato G. (1972) "Il commercio con l'estero della Mesopotamia meridionale nel 3. Millennio av. Cr. Alla luce delle fonti letterarie e lessicali sumeriche.” Mesopotamia, VII, 43-166.

Peyronel L. (2000) "Sigilli Harappani e Dilmuniti dalla Mesopotamia e dalla Susiana. Note sul

Pezzoli-Olgiati D. (2000) "Images of cities in Ancient Religions: Some methodological considerations.” Zurich. Site <http://www.cwru.edu/affil/GAIR/papers/2000papers/Daria.html>

Possehl G.L. (1984) "Of Men." In J.M. Kenoyer (ed.) From Sumer to Meluhha: contributions to the archaeology of South and West Asia in memory of George F. Dales, Jr. Wisconsin Archaeological Reports, 3, pp. 179-186.

Possehl G.L. (2002) The Indus Civilization. A Contemporary Perspective. Walnut Creek.

Potts T. (1994) Mesopotamia and the East. Oxford.

Rao S.R. (1973) Lothal and the Indus Civilization. Bombay.

Rao S.R. (1979) Lothal a Harappan Port Town (1955-62). Memoirs of the Archaeological Survey of India, 78, Volume 1. New Delhi.

Rao S.R. (1985) Lothal a Harappan Port Town (1955-62). Memoirs of the Archaeological Survey of India, 78, Volume 2. New Delhi.

Reade J. (1979) Early Etched Beads and the Indus-Mesopotamia Trade. London.

Reade J. (2001) "Assyrian King-Lists, The Royal Tombs of Ur, and Indus Origins.” Journal of Near Eastern Studies, 60, 1, 1-38.

Roux V. \& Matarasso P. (2000) "Les perles in cornaline harappéennes. Pratiques techniques et technosystéme.” In V. Roux (ed.) Cornaline de l'Inde. Des pratiques techniques de Cambay aux technosystémes de l'Indus. Paris,417-438.

Sax M. (1991) "The Composition of the Materials of the First Millennium BC Cylinder Seals from Western Asia.” In P. Budd, B. Chapman, C. Jackson, R. Janaway \& B. Ottaway (eds.) Archaeological Sciences 1989. Exeter.

Shah S.G.M. \& A. Parpola (1991) Corpus of Indus Seals and Inscriptions. 2. Collections in Pakistan. Helsinki. 
Simoons F.J. (1968) A Ceremonial Ox of India. The Mithan in Nature, Culture and History with Notes on Domestication of Common Cattle. Madison.

Sollberger E. (1970) "The Problem of Magan and Meluhha." Bulletin of the University of London, 8-9, pp. $247-250$.

2734

Tallon F. (1995) Les Pierres Précieuses de l’Orient Ancien des Sumériens aux Sassanides. Paris.

Tosi M. (1991) “The Indus Civilization beyond the Indian Subcontinent.” In M. Jansen, M. Mulloy \&

Vidale M. (2000) The Archaeology of Indus Crafts. Indus craftspeople and why we study them. IsIAO Reports and Memoirs, IV, Series Minor, Rome.

Vidale M. (2002) "Aspects of the Indian bead trade in the Bronze Age." Paper presented at the International Congress "Early navigation and Trade in the Indian Ocean," Ravenna, 5 June 2002.

Vidale M. (in print) "The Short-Horned Bull on the Indus Seals: a Symbol of the Families in the Western Trade?” Forthcoming in South Asian Archaeology 2002, Bonn.

Vidale M. \& P. Bianchetti (1997) "Mineralogical Identification of Green Semiprecious Stones from Pakistan.” In R. Allchin \& B. Allchin (eds.) South Asian Archaeology, 1995. New Delhi, Vol. 2, $947-$ 953.

Vidale M. \& P. Bianchetti (1998-1999) "Identification of grossular (garnet) as a possible item of longdistance trade from the Indus Valley to Mesopotamia in the Third millennium BC." Ancient Sindh, 5, $39-43$.

Vidale (2004) "Growing in a Foreign World. For a History of the "Meluhha Villages" in Mesopotamia in the 3rd Millennium BC" in A. Panaino and A. Piras (eds.) Melammu Symposia 4 Winkelmann S. (1999) "Ein Stempelsiegel mit alt-elamischer Strichschsrift." Archäologischen Mitteilungen aus Iran und Turan, 31, pp. 23-32.

Witzel, Michael (1999) "Substrate Languages in Old Indo-Aryan (Rigvedic, Middle and Late Vedic)" Electronic Journal of Vedic Studies. 5 (1)

Zarins J. (2002) "Magan Ship Builders at the Ur-III Lagash Dockyards." Paper presented at the International Congress "Early Navigation and Trade in the Indian Ocean," Ravenna, 5 June 2002.

Zarins Y. (2003) "Magan Shipbuilders at the Ur III Lagash State Dockyards (2062-2025 BC)." In E. Olijdam \& R.H. Spoor (eds.) Intercultural Relations Between South and Southwest Asia. Studies in 